\title{
Análise Microscópica Comparativa do Comportamento Tecidual Medular de Ratos Frente ao Implante de Tríóxido Mineral Agregado ou Cimento à Base de Pasta Zinco-Enólica.
}

\section{Augusto Bodanezi}

Dissertação apresentada ̀̀ Faculdade de Odontologia de Bauru, da Universidade de São Paulo, como parte dos requisitos para obtenção do título de Mestre em Odontologia, na área de Endodontia

(Edição Revisada) 
Análise Microscópica Comparativa do Comportamento Tecidual Medular de Ratos Frente ao Implante de Tríóxido Mineral Agregado ou Cimento à Base de Pasta Zinco-Enólica.

\section{Augusto Bodanezi}

DIssertação apresentada à Faculdade de Odontologia de Bauru, da Universidade de São Paulo, como parte dos requisitos para obtenção do título de Mestre em Odontologia, na área de Endodontia

(Edição Revisada)

Orientador: Prof. Dr. Norberti Bernardineli 


\section{Bodanezi, Augusto}

B 631 a Análise microscópica comparativa do comportamento tecidual medular de ratos frente ao implante de trióxido mineral agregado ou cimento à base de pasta zinco-enólica. / Augusto Bodanezi. Bauru, 2005.

134 p.: il.; $30 \mathrm{~cm}$

Dissertação. (Mestrado) - Faculdade de Odontologia de Bauru, Universidade de São Paulo

Orientador: Prof. Dr. Norberti Bernardineli

Autorizo, exclusivamente para fins acadêmicos e científicos, a reprodução total ou parcial desta dissertação, por processos fotocopiadores e outros meios eletrônicos.

Assinatura : 


\section{AUGUSTO BODANEZI}

08 de janeiro de 1979

Nascimento

Passo Fundo - RS

Beatriz Vanni Bodanezi

Filiação

Edgar Augusto Bodanezi

$1996-2001$

Curso de graduação em Odontologia

Universidade de Passo

Fundo - RS

$2002-2003$

Curso de pós- graduação em Endodontia lato sensu - Faculdade de Odontologia de Bauru USP-SP

$2003-2005$

Curso de pós- graduação em Endodontia stricto sensu - Faculdade de Odontologia de Bauru USP-SP

Associacões

IADR - International Association for Dental Research

SBPqO - Sociedade Brasileira de Pesquisa Odontológica 
AGRADECIMENTOS 


\section{HOMENAGENS}

À Deus,

Percorre teu caminho com fé, pois Dele vem o equilíbrio, que não te deixa esmorecer.

Assume a verdade e Luta para propagar a bondade. 
À minha família querida em especial à meus pais Beatriz e Edgar, e minha irmã Rafaela,

Doar, doar, doar,

Quanto amor é comunicado sem gestos nem palavras,

Quanto cuidado emana como se a distância não existisse,

Quanta força é transmitida pela confiança,

Alegria, alegria, alegria

Mais uma de nossas vitórias.

Á minha namorada Etiene, e á seus familiares, em especial Dona Marisa e Seu Ademir,

Te disse de minha força, que sem carinho, nada mais é do que pluma ao vento.

Te disse de minhas fraquezas, que

sem ajuda, roubam minha paz.

Te disse de minha solidão, que sem

tua companfia,, me desvia do rumo.

Tu me disseste: segura firme na minha mão pois ainda temos muito a construir e somente de nós depende a felicidade. 


\section{AGRADECIMENTOS}

Ao professor e amigo Dr. Norberti Bernardineli,

Dádiva é poder regar a árvore, para que cresşa e dê bons frutos.

Tarefa árdua é ensinar a autodisciplina, e ao mesmo tempo nortear de forma singela.

O meu sincero muito obrigado!

Ao professor Dr. Roberto Brandão Garcia,

Perfeição, retidão e consideração,

Alicerces da harmonia, amizade e ciência.

O meu sincero muito obrigado!

Ao professor Dr. Ivaldo Gomes de Moraes,

A estima e a sabedoria são evidências de que,

por mais incógnito o propósito da vida,

nossa existência não é vã.

O meu sincero muito obrigado!

Ao professor Dr. Clóvis Monteiro Bramante,

Digno de honra é Capidar o diamante, para que acenda brilho próprio e resplandeça, mesmo nos momentos de escuridão.

O meu sincero muito obrigado! 
Aos professores Drs. Alceu Berbert e José Mondelli,

Como o minerador revolve a bateia com paciência e dedicação, o ourives, requintado e minucioso, Lavoreia a pepita para que sintamos o entusiasmo que a beleza traz, ao admirar a jóia. O meu sincero muito obrigado!

Aos professores Drs. Rumio Taga, Gerson Francisco de Assis, e professoras Dras. Marília Buzalaf e Tereza Cristina,

Ao ensaiar a partitura com afinco,

o maestro torna a orquestra cada vez mais harmônica.

O meu sincero muito obrigado!

Ao professor Dr. José Roberto Pereira Lauris,

O universal não tem fundamento na realidade, mas deriva das semelhanças existentes entre as coisas.

O meu sincero muito obrigado! William Ockfam

Aos professores Drs. José Roberto Vanni, José Antônio Poli de Figueiredo e Dra. Lilian Neuvald,

Acreditar no sonho é metade da conquista.

Confiar e incentivar para que o sonho se realize é sobre-humano.

O meu sincero muito obrigado! 
Aos funcionarios da Endodontia, Dona Neide Leandro, Suely Bettio, Edimauro de Andrade e Patrícia Lopes,

Nos 6astidores do palco iluminado, resultado da empatia e convivência,, acontece o verdadeiro espetáculo.

O meu sincero muito obrigado!

Às funcionarias da Histologia, Danielle Ceolin, Tânia Cestari, Teresa e Divina,

Acorde de flautim silencioso,

a certeza de que a sinfonia incorpora cada vez mais instrumentos.

O meu sincero muito obrigado!

Aos funcionários da biblioteca, Vera, Valéria, Rita, César e equipe. Aos funcionários do Biotério, Luis Carlos, Erasmo, Richard e Wagner.

Aos demais professores e funcionários da Faculdade de Odontologia de Bauru,

$\mathcal{N a}$ imenso escuridão, a estrela brilha serena e, na paz infinita, inspira o amanhecer.

O meu sincero muito obrigado! 
Aos colegas de Pós-Graduação de todas as áreas, em especial os companheiros e amigos da Endodontia, Amélio Borges Taveira, Danieli Siqueira, Luciano Cintra, Thaís Mendonça, Norberto Broon, Járcio Baldi, Eduardo Bortoluzzi, Fernanda Moraes, Everdam Carneiro, Renato Menezes, Fábio Picolli, Viviane Brosco, Giovana Canova e Rogério de Souza,

$\mathcal{N}$ as tuas palavras descubro que a amizade e o saber, são lentes que me fazem enxergar o mundo de maneira que jamais imaginei.

O meu sincero muito obrigado!

Aos amigos fraternos Letícia Monteiro, Josiane Simas, Fernanda Brighenti, José Gustavo Rodrigues e,

Como veio de mármore encoberto,

o tempo e a distância enriquecem cada vez mais a beleza da rocha.

O meu sincero muito obrigado!

Á Faculdade de Odontologia de Bauru, da Universidade de São Paulo,

Desperta no teu filho a ânsia pelo saber, pois na época da colheita, o conhecimento propagar-se-á como sementes de algodoeiro, conduzidas pela suave brisa no fim do outono.

Ao Conselho Nacional de Desenvolvimento Científico e Técnológico, e á empresa Angelus Ltda,

O meu sincero muito obrigado! 


\section{SUMÁRIO}

LISTA DE ABREVIATURAS, SIGLAS E SÍMBOLOS..............................................ii

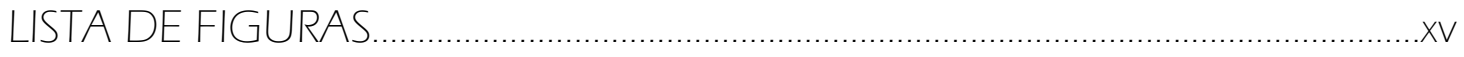

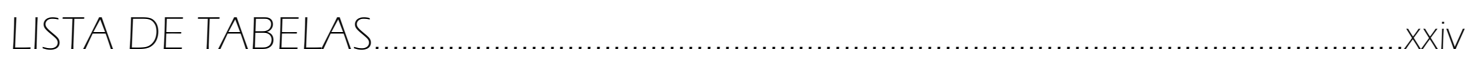

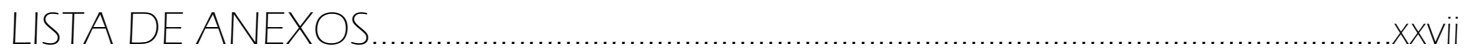

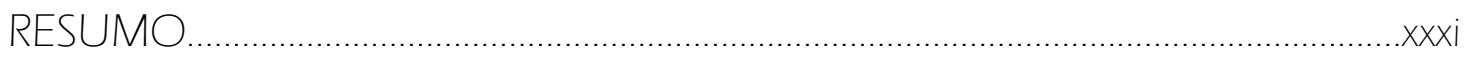

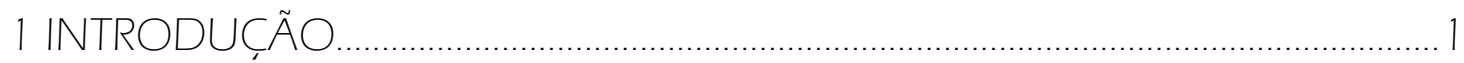

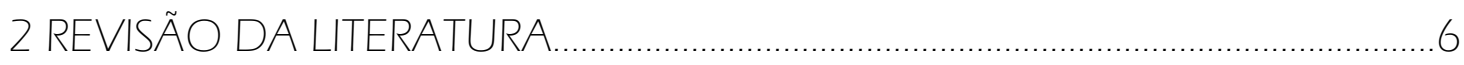

3 PROPOSIÇÃO

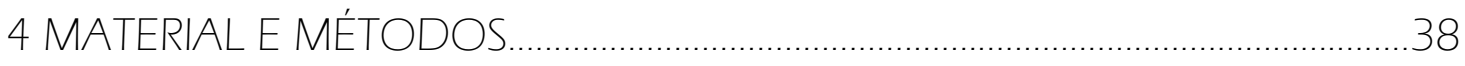

5 RESULTADOS

6 DISCUSSÃO

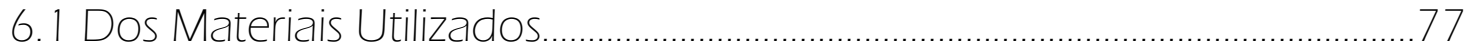

6.2 Do Método

6.3 Dos Resultados

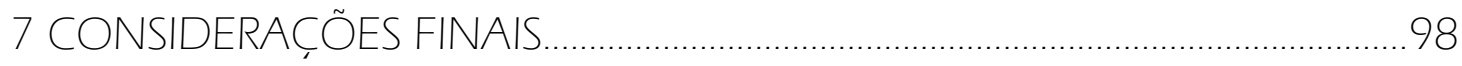

8 CONCLUSÕES

ANEXOS

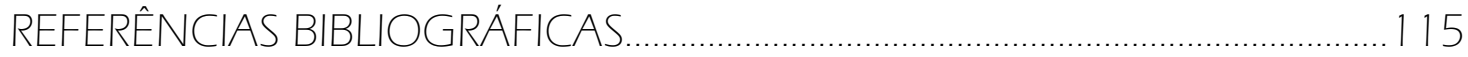

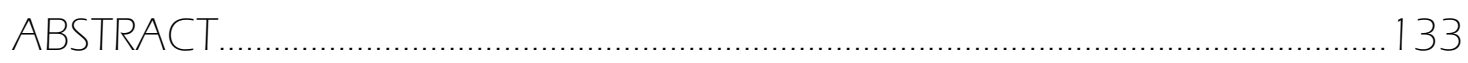




\section{LISTA DE ABREVIATURAS, SIGLAS E SÍMBOLOS}

\begin{tabular}{|c|c|}
\hline ADA & American Dental Association \\
\hline Ag & símbolo químico da prata \\
\hline As & símbolo químico do arsênio \\
\hline $\mathrm{AL}_{2} \mathrm{O}_{3}$ & oxido de alumínio \\
\hline ANOVA & análise de variânçia \\
\hline $\mathrm{Bi}$ & símbolo químico do bismuto \\
\hline $\mathrm{Bi}_{2} \mathrm{O}_{3}$ & óxido de bismuto \\
\hline $\mathrm{Ca}$ & simbolo químico do cálcio \\
\hline $\mathrm{CaO}$ & óxido de cálcio \\
\hline $\mathrm{Ca}(\mathrm{OH})_{2}$ & fórmula química do hidróxido de cálcio \\
\hline Cel. & células \\
\hline $\mathrm{CH}_{3}$ & fórmula química do iodofórmio \\
\hline $\mathrm{C}_{3} \mathrm{H}_{5}(\mathrm{OH})_{3}$ & fórmula química da glicerina \\
\hline $\mathrm{Cl}$ & símbolo químico do cloro \\
\hline $\mathrm{Cr}$ & símbolo químico do cromo \\
\hline $\mathrm{Cu}$ & símbolo químico do cobre \\
\hline Desorg. & desorganização \\
\hline EBA & ácido orto-etóxi-benzóico \\
\hline EDTA & ácido etileno diamino tetra-acético \\
\hline FDI & Fédération Dentaire Internationale \\
\hline $\mathrm{Fe}$ & símbolo químico do ferro \\
\hline $\mathrm{Fe}_{2} \mathrm{O}_{3}$ & óxido férrico \\
\hline Fig. & figura \\
\hline 9 & gramas \\
\hline $\mathrm{HC}$ & hipótese de não-significância \\
\hline HE & hematoxilina e eosina \\
\hline $\mathrm{H}_{2} \mathrm{~S}$ & sulfeto de hidrogênio \\
\hline Inflam. & inflamatório \\
\hline IRM & material restaurador intermediário \\
\hline
\end{tabular}




\begin{tabular}{|c|c|}
\hline ISO & International Organization for Standartization \\
\hline $\mathrm{K}_{2} \mathrm{O}$ & óxido de potássio \\
\hline Ltda. & sociedade limitada \\
\hline LDPE & polietileno de baixa densidade \\
\hline $\mathrm{mg}$ & miligramas \\
\hline $\mathrm{MgO}$ & óxido de magnésio \\
\hline $\mathrm{mm}$ & milímetros \\
\hline $\mathrm{ml} / \mathrm{g}$ & mililitros por grama de peso \\
\hline MTA & trióxido mineral agregado \\
\hline$n$ & tamanho da amostra \\
\hline N. & número \\
\hline $\mathrm{Na}_{2} \mathrm{O}$ & óxido de sódio \\
\hline $\mathrm{NH}_{4}$ & amônia \\
\hline$p$ & nivel de significância \\
\hline P.A. & pró-análise \\
\hline $\mathrm{Pb}$ & símbolo químico do chumbo \\
\hline PE & polietileno \\
\hline$P / L$ & relação pó-líquido \\
\hline P.V.C & cloreto de polivinil \\
\hline$S / A$ & sociedade anônima \\
\hline $\mathrm{SiO}_{2}$ & óxido de silício \\
\hline $\mathrm{SO}_{3}$ & óxido sulfuroso \\
\hline $\mathrm{SO}_{4}$ & óxido sulfúrico \\
\hline Tec. & tecidual \\
\hline Trabéc. & trabéculas \\
\hline USP & Universidade de São Paulo \\
\hline$x$ & fator de ampliação da imagem \\
\hline & símbolo químico do zinco \\
\hline
\end{tabular}


$\mu \mathrm{m}$

$\%$

(R)

$=$

*

$\circ$ micrômetro

por cento

marca registrada

igual

vide rodapé da página

número 


\section{LISTA DE FIGURAS}

FIGURA 1.1

FIGURA 1.2

FIGURA 1.3

FIGURA 1.4

FIGURA 1.5

FIGURA 1.6

FIGURA 2

FIGURA 3.1
Proporcionamento da pasta zinco-enólica, iodofórmio e glicerina sobre a placa de espatulação. 42

Porporcionamento da pasta zinco-enóllica, subnitrato de bismuto e glicerina sobre a placa de espatulação..

Proporcionamento da pasta zinco-enólica, iodofórmio, hidróxido de cálcio e glicerina sobre a placa de espatulação.

Proporcionamento da pasta zinco-enólica, subnitrado de bismuto, hidróxido de cálcio e glicerina sobre a placa de espatulação....................................................................

Proporcionamento do trióxido mineral agregado e água destilada sobre a placa de espatulação. 43

Aspecto dos tubos de P.V.C. siliconizados 43

Animal tricotomizado. 44

Exposição da tíbia direita do rato. .45 
FIGURA 6.1:

FIGURA 6.2:

FIGURA 7.1

FIGURA 7.2

FIGURA 7.3

FIGURA 8.1:
Consistência do cimento à base de base zincoenólica após mistura e espatulação com os aditivos

Consistência do trióxido mineral agregado após mistura com água destilada..

Limite representativo de preenchimento dos tubos providos de pasta zinco-enólica e aditivos.

Limite de preenchimento dos tubos dotados de agregado de trióxido mineral.

Vista lateral do tubo denotando seu comprimento e o preenchimento completo pelos materiaisl.

Implantação, na tíbia, de tubo preenchido com cimento à base de óxido de zinco e

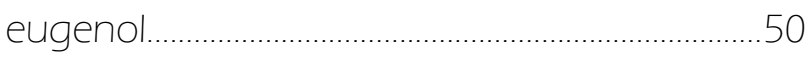


FIGURA 8.2:

FIGURA 9.1:

FIGURA 9.2:

FIGURA 10

FIGURA 11

FIGURA 11.1

FIGURA 11.2

FIGURA 12.1

FIGURA 12.2
Implantação, no fêmur, de tubo preenchido com trióxido mineral agregado.

50

Aspecto da sutura muscular.

51

Aspecto da sutura da pele.

51

Radiografia pós-operatória evidenciando a localização dos implantes no interior dos ossos

Aplicação da medicação pós-operatória nos animais

Aspecto do osso fêmural preparado para desmineralização

Tíbia após remoção dos tecidos musculares e pronta para demineralização. 52

Fotomicrografia da reação tecidual dos tubos vazios aos 30 dias (aumento $4 X)$........ 60

Fotomicrografia da reação tecidual dos tubos vazios em maior aumento 130 dias laumento 40X 
FIGURA 13.1

FIGURA 13.2

FIGURA 14.1

FIGURA 14.2

FIGURA 15.1

FIGURA 15.2

FIGURA 16.1
Fotomicrografia da reação tecidual ao trióxido mineral agregado aos 30 dias (aumento 4X) .60

Fotomicrografia da reação tecidual ao trióxido mineral agregado aos 30 dias (aumento 40X) 60

Fotomicrografia da reação tecidual à pasta zinco-enólica acrescida de subnitrato de bismuto, aos 30 dias (aumento 4X). 60

Fotomicrografia da reação tecidual à pasta zinco-enólica acrescida de subnitrato de bismuto, aos 30 dias (aumento 40X)..........60

Fotomicrografia da reação tecidual à pasta zinco-enólica acrescida de subnitrato de bismuto e hidróxido de cálcio, aos 30 dias (aumento 10X)

Fotomicrografia da reação tecidual à pasta zinco-enólica acrescida de subnitrato de bismuto e hidróxido de cálcio, aos 30 dias (aumento 40X)

Fotomicrografia evidenciando células gigantes multinucleadas adjacentes ao tubo preenchido com pasta zinco-enólica acrescida de hidróxido de cálcio e subnitrto de bismuto 130 dias - aumento 40X) .61 
FIGURA 16.2

FIGURA 17.1

FIGURA 17.2

FIGURA 18.1

FIGURA 18.2

FIGURA 19.1

FIGURA 19.2
Fotomicrografia evidenciando células gigantes multinucleadas do tipo Langhans adjacentes ao tubo preenchido com pasta zinco-enólica acrescida de subnitrado de bismuto (30 dias - aumento 40X). 61

Fotomicrografia da reação tecidual, aos 30 dias, à pasta zinco-enólica acrescida de iodofórmio (aumento 4X).

Fotomicrografia da reação tecidual, aos 30 dias, à pasta zinco-enólica acrescida de iodofórmio (aumento 40X)... 62

Fotomicrografia da reação tecidual, aos 30 dias, à pasta zinco-enólica acrescida de iodofórmio e hidróxido de cálcio (aumento 10XI

Fotomicrografia da reação tecidual, aos 30 dias, à pasta zinco-enólica acrescida de iodofórmio e hidróxido de cálcio (aumento $40 \times 1$

Fotomicrografia da reação tecidual dos tubos vazios aos 60 dias (aumento $4 \times 1$ 65

Fotomicrografia da reação tecidual dos tubos vazios aos 60 dias (aumento 10X) .65 
FIGURA 20.1

FIGURA 20.2

FIGURA 21.1

FIGURA 21.2

FIGURA 22.1

FIGURA 22.2

FIGURA 23.1

FIGURA 23.2
Fotomicrografia da reação tecidual ao trióxido mineral agregado aos 60 dias laumento $4 X$ )

Fotomicrografia da reação tecidual ao trióxido mineral agregado aos 60 dias (aumento 40X). 65

Fotomicrografia da reação tecidual à pasta zinco-enólica acrescida de subnitrato de bismuto, aos 60 dias (aumento $4 X)$. 65

Fotomicrografia da reação tecidual à pasta zinco-enólica acrescida de subnitrato de bismuto, aos 60 dias (aumento 40X) ...........65

Fotomicrografia da reação tecidual à pasta zinco-enólica acrescida de subnitrato de bismuto e hidróxido de cálcio, aos 60 dias (aumento 10X) .66

Fotomicrografia da reação tecidual à pasta zinco-enólica acrescida de subnitrato de bismuto e hidróxido de cálcio, aos 60 dias (aumento 40X) 66

Fotomicrografia da reação tecidual, aos 60 dias, à pasta zinco-enólica acrescida de iodofórmio (aumento 4X). 66

Fotomicrografia da reação tecidual, aos 60 dias, à pasta zinco-enólica acrescida de iodofórmio (aumento 40X). .66 
FIGURA 24.1

Fotomicrografia da reação tecidual, aos 60 dias, à pasta zinco-enólica acrescida de iodofórmio e hidróxido de cálcio (aumento 10X) .66

FIGURA 24.2

Fotomicrografia da reação tecidual, aos 60 dias, à pasta zinco-enólica acrescida de iodofórmio e hidróxido de cálcio (aumento 40X)

FIGURA 25.1

Fotomicrografia da reação tecidual dos tubos vazios aos 90 dias (aumento $4 X)$ 69

FIGURA 25.2

Fotomicrografia da reação tecidual dos tubos vazios aos 90 dias (aumento 10X). 69

FIGURA 26.1

Fotomicrografia da reação tecidual ao trióxido mineral agregado aos 90 dias (aumento 4X)

FIGURA 26.2

Fotomicrografia da reação tecidual ao trióxido mineral agregado aos 90 dias (aumento 40X)

FIGURA 27.1

Fotomicrografia da reação tecidual à pasta zinco-enólica acrescida de subnitrato de bismuto, aos 90 dias (aumento 4X)... 69

FIGURA 27.2

Fotomicrografia da reação tecidual à pasta zinco-enólica acrescida de subnitrato de bismuto, aos 90 dias (aumento 40X)..... 69 
FIGURA 28.1

FIGURA 28.2

FIGURA 29.1

FIGURA 29.2

FIGURA 30.1

FIGURA 30.2

FIGURA 31

FIGURA 32
Fotomicrografia da reação tecidual à pasta zinco-enólica acrescida de subnitrato de bismuto e hidróxido de cálcio, aos 90 dias (aumento 10X) 70

Fotomicrografia da reação tecidual à pasta zinco-enólica acrescida de subnitrato de bismuto e hidróxido de cálcio, aos 90 dias (aumento 40X) 70

Fotomicrografia da reação tecidual, aos 90 dias, à pasta zinco-enólica acrescida de iodofórmio (aumento 4X) 70

Fotomicrografia da reação tecidual, aos 90 dias, à pasta zinco-enólica acrescida de iodofórmio (aumento 40X). 70

Fotomicrografia da reação tecidual, aos 90 dias, à pasta zinco-enólica acrescida de iodofórmio e hidróxido de cálcio (aumento 10X). .70

Fotomicrografia da reação tecidual, aos 90 dias, à pasta zinco-enólica acrescida de iodofórmio e hidróxido de cálcio (aumento 40X).

Gráfico representativo da evolução do infiltrado celular inflamatório no decorrer dos períodos experimentais. .73

Gráfico representativo da quantidade de amostras com células gigantes multinucleadas presentes, no decorrer dos períodos experimentais. 73 
FIGURA 33:

FIGURA 34

FIGURA 35

FIGURA 36
Gráfico referente á organização do tecido de granulação, nos diferentes períodos experimentais. 74

Gráfico demonstrativo da presença de necrose de coagulação nos diversos grupos em cada período experimental.. 74

Grafico representativo da presença de tecido duro neoformado na interface do tubo com o tecido medular, nos diferentes intervalos experimentais. 75

Grafico demonstrativo da presença de barreira osteóide completa separando o tecido de granulação do tecido conjuntivo medular, nos diversos períodos experimentais .75 


\section{LISTA DE TABELAS}

TABELA 1

TABELA 2:

TABELA 3

TABELA 4

TABELA 5

TABELA 6

TABELA 7

TABELA 8

TABELA 9

TABELA 10
Fórmula da pasta zinco-enólica LS®...........39.

Fórmula do cimento reparador MTA $($.......39

Fórmula do iodofórmio. 39

Fórmula do subnitrato de bismuto. 40

Fórmula do hidróxido de cálcio P.A. 40

Fórmula da glicerina líquida 40

Composição do cimento utilizado no grupo 1 40

Composição do cimento utilizado no grupo 2

Composição do cimento utilizado no grupo 3

Composição do cimento utilizado no grupo 4. 
TABELA 11

TABELA 12

TABELA 13

TABELA 14

TABELA 15

TABELA 16

TABELA 17

TABELA 18

Composição do cimento utilizado no grupo

5

Composição dos tubos de P.V.C

Número de amostras de cada material em função dos diferentes períodos experimentais. 48

Critérios de avaliação microscópica e respectivos valores ordinais relativos ao infiltrado inflamatório crônico.. .54

Critérios de avaliação microscópica e respectivos valores ordinais referentes à presença de necrose tecidual. 54

Critérios de avaliação microscópica e respectivos valores ordinais quanto á presença de células gigantes multinucleadas....................................................5

Critérios de avaliação microscópica e respectivos valores ordinais referentes ao aspecto fibroso do tecido de aranulacão..54

Critérios de avaliação microscópica e respectivos valores ordinais quanto à quantidade de trabéculas ósseas na interface com o os materiais............................56 
TABELA 19

Critérios de avaliação microscópica e respectivos valores ordinais referentes ao grau de formação de barreira óssea entre 0 tecido de aranulação e o medular. .56

TABELA 20

Demonstrativo dos resultados significantes obtidos através da análise de variância entre os grupos, dentro de cada período experimental........

TABELA 21

Demonstrativo dos resultados significantes obtidos através da análise de variância de cada grupo nos diversos períodos

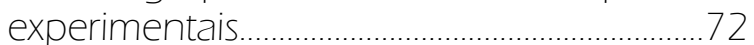

TABELA 22

Legenda explicativa para distinção dos grupos nos gráficos comparativos.. 72 


\section{LISTA DE ANEXOS}

Escores atribuidos aos diferentes grupos no período 30 dias.

Escores atribuídos aos diferentes grupos no período 60 dias

Medianas referentes à análise de variância dos grupos experimentais e controle aos 30 dias.

ANEXO G

Quantificação da presença de plasmócitos e linfócitos observados nas amostras, em função dos períodos experimentais.

ANEXOH

Dados numéricos referentes à análise de variância do infiltrado inflamatório crônico, no período de 30 dias. 


\section{ANEXO I}

ANEXO J

ANEXO K

ANEXO L

ANEXO M

ANEXO N

ANEXO O

ANEXOP
Dados numéricos referentes à análise de variância da intensidade do infiltrado inflamatório crônico. no período de 60 dias. 108

Dados numéricos referentes à análise de variância da intensidade do infiltrado inflamatório crônico. no período de 90 dias. 108

Dados numéricos provenientes da análise de variância relativa à presença de células gigantes multinucleadas no período de 30 dias. 108

Dados numéricos provenientes da análise de variância relativa à presença de células gigantes multinucleadas no período de 60 dias. 109

Dados numéricos provenientes da análise de variância relativa à presença de células gigantes multinucleadas no período de 90 dias. 109

Dados numéricos relativos à análise de variância do grau de organização do tecido de granulação observado no período de 30 dia 109

Dados numéricos relativos à análise de variância do grau de organização do tecido de granulação observado no período de 60 dias. 110

Dados numéricos relativos à análise de variância do grau de organização do tecido de aranulacão. no período de 90 dias. 110 


\section{ANEXO O}

ANEXO R

ANEXOS

ANEXOT

ANEXO U

ANEXO V

ANEXO W

Dados numéricos provenientes da análise de variância quanto à presença de necrose tecidual observada no período de 30 dias. 110

Dados numéricos provenientes da análise de variância quanto à presença de necrose tecidual, no período de 60 dias.

Dados numéricos provenientes da análise de variância quanto à presença de necrose tecidual, no período de 90 dias. 111

Dados numéricos referentes à análise de variância da quantidade de trabéculas ósseas adjacentes à extremidade do tubo, observadas no período de 30 dias. 111.

Dados numéricos referentes à análise de variância da quantidade de trabéculas ósseas adjacentes à extremidade do tubo, observadas no período de 60 dias.

Dados numéricos referentes à análise de variância da quantidade de trabéculas ósseas adjacentes à extremidade do tubo, observadas no período de 90 dias.

Dados relativos à análise de variância da quantidade de barreira óssea presente entre o tecido medular e tecido fibroso, observada no período de 30 dias. 


\section{ANEXOX}

ANEXO Y

ANEXO Z
Dados relativos à análise de variância da quantidade de barreira óssea presente entre o tecido medular e tecido fibroso, observada no período de 60 dias

Dados relativos à análise de variância da quantidade de barreira óssea presente entre o tecido medular e tecido fibroso, observada no período de 90 dias. 113

Reprodução do parecer do Comitê de Ética no Ensino e Pesquisa em Animais. 114. 
RESUMO 


\section{RESUMO}

O propósito deste estudo foi verificar o comportamento inflamatório do tecido osteomedular de ratos quando em contato com agregado de trióxido mineral (MTA Angelus $($ ) ) ou pasta de moldagem zinco-enólica LS (VigodentR) adicionada de um tipo de substância radiopacificadora (subnitrato de bismuto ou iodofórmio) e acrescida ou não de hidróxido de cálcio. O grupo controle era constituído por tubos vazios. Os implantes foram inseridos no interior da tíbia e fêmur direitos de cada um dos 51 ratos totalizando 102 amostras. Em cada um dos períodos experimentais de 30, 60 e 90 dias, coletou-se 34 espécimes que, após processamento histotécnico, foram microscopicamente analisados e seus fenômenos julgados com base em um sistema de escores.. Os testes estatísticos de Kruskal-Wallis, Mann Whitney e Dunn, nos permitiram verificar que o reparo aconteceu associado a ambos materiais, embora mais tardio nos grupos com óxido de zinco e eugenol ( $p=0.05)$. A adição de um ou outro agente radiopacificador não alterou o caráter inflamatório da pasta e a incorporação de hidróxido de cálcio parece não melhorar seu comportamento biológico( $P=0.05)$. 
INTRODUÇÃO 


\section{INTRODUÇÃO}

Desde a comprovação das bactérias como agentes iniciadores e perpetuadores das doenças pulpares e periapicais ${ }^{54}$, a especialidade endodôntica preocupa-se em eliminar, neutralizar ou impedir o acesso ou eliminar os microrganismos e seus produtos dos canais radiculares e estruturas periodontais por meio do tratamento convencional ou cirúrgico.

Os esforços da odontologia atual concentram-se na manutenção dos dentes naturais do paciente e a cirurgia paraendodôntica traduz-se no recurso conclusivo prévio à extração dental, após constatado o fracasso do tratamento ortógrado e inviabilidade de uma reintervenção.

A obturação retrógrada é indicada como modalidade cirúrgica quando o objetivo é selar apicalmente o canal infectado e aumentar a probabilidade de sucesso do tratamento². Esta afirmação é também dividida por TANOMARU FILHO et al ${ }^{96}$, que verificaram maior capacidade de selamento apical quando do emprego das técnicas de obturação retrógrada.

Um dos propósitos da colocação do material retrobturador, de acordo com PITT FORD ${ }^{84}$, é evitar o acesso de produtos microbianos, provenientes do sistema de canais radiculares, aos tecidos periapicais. Além desta propriedade, o mesmo deveria ser atóxico, não reabsorvivel e exibir capacidade osteoindutora ou ao menos não interferir com a transcorrência normal do reparo nos tecidos paraendodônticos. A superfície de contato entre o cimento retrobturador e os tecidos periodontais é ampla, logo a menor irritação presente é traduzida em inflamação. Segundo TROWBRIDGE e 
EMLING ${ }^{108}$, a persistência de infecção local pode impedir a formação completa do tecido conjuntivo e perpetuar a lesão inflamatória.

Outras qualidades como facilidade de manipulação, simplicidade na obtenção, baixo custo, radiopacidade adequada e manutenção das propriedades físicas em meio úmido deveriam ser também condições essenciais a um cimento retrobturador. .

Até o momento, nenhum material combina todas as qualidades ideais $^{99}$, no entanto, pesquisadores sugerem que algumas propriedades deveriam ser retiradas e outras modificadas, na tentativa de se formular um material retrobturador ideal. Exemplos destes esforços são o amálgama de prata sem zinco, os cimentos de óxido de zinco e eugenol modificados, os cimentos de ionômero de vidro, as resinas compostas e os cimentos de base epóxica.

Recentemente foi lançado no mercado um cimento reparador denominado trióxido mineral agregado (MTA), que além de suas diversas qualificações de uso, é considerado excelente selador de cavidades retrógradas ${ }^{99,4}$ e biocompatível ao ponto de induzir a deposição de tecido duro 99,104,47,48.

O hidróxido de cálcio, quando incorporado aos cimentos obturadores, é cientificamente associado à antecipação do reparo, como relatado por TANOMARU FILHO et al ${ }^{97}$ e à deposição de tecido duro $43,74,6,47,35,48,90$.

HOLLAND et al sugerem que os mecanismos de ação do agregado de trióxido mineral e do hidróxido de cálcio apresentem similaridades ${ }^{47,48}$.

A pasta zinco-enólica é utilizada à décadas na odontologia como material de moldagem devido á fidelidade de cópia, baixo custo e facilidade de manipulação ${ }^{55}$. Até o advento de cimentos específicos 
para proteção periodontal, este material era empregado na proteção pós-operatória imediata de feridas pós-cirúrgicas ${ }^{79,80}$.

$\bigcirc$ estudo do comportamento da pasta zinco-enólica como material retrobturador foi concebido por BERNARDINELI ${ }^{7}$,em 1993, que constatou ínfimos índices de infiltração de corante associados à este composto, observações estas reforçadas, em seguida, pelos experimentos de DUTRA ${ }^{29}$ e CUSTÓDIO ${ }^{24}$.

MORAIS ${ }^{71}$,em 2003, pesquisou o comportamento da pasta à base de óxido de zinco e eugenol quando em contato com o tecido subcutâneo de animais e verificou que, após 60 dias, os fenômenos

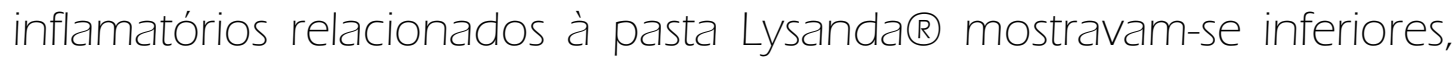
qualitativamente, àqueles observados com o trióxido mineral agregado ou cimento tipo Portland acrescido de iodofórmio.

Um dos inconvenientes deste material é a ausência de radiopacidade para ser utilizada como cimento retrobturador, logo BODANEZI e BERNARDINELI" pesquisaram "in vitro" a adição de substâncias radiopacificadoras comumente encontrados na endodontia. Os autores verificaram que iodofórmio e o subnitrato de bismuto, nas concentrações de 20\% em peso, conferiam contraste radiográfico equivalente à guta-percha, utilizada como controle positivo, e superiores ao óxido de zinco e sulfato de bário.

Segundo MITTAL, CHANDRA e CHANDRA ${ }^{70}$, o teste em ratos é uma forma econômica de se testar os efeitos biológicos dos cimentos endodônticos.

As semelhanças entre ratos e humanos apareceram de forma mais específica depois da melhor concepção da biologia dos ratos obtida pelo mapeamento da maior parte de seu genoma, em 2004, o que é muito útil para estudos fisiológicos e farmacológicos, 
porque o rato é o animai mais empregado nestes tipos de estudo e apesar da alta variabilidade de espécies, todas evidenciam os resultados em humanos 57

método de implantação intra-óssea em animais tenta reproduzir o processo de reparação óssea maxilar humana subseqüente a um processo cirúrgico paraendodôntico. A maior sensibilidade e confiabilidade deste teste ${ }^{66}$, associado às reações inflamatórias menos severas aos materiais, quando comparado com a implantação em tecido subcutâneo ${ }^{72}$, propõe-se a complementar os ensaios laboratoriais e biológicos executados anteriormente.

Incentivados pelas descobertas já descritas e, sabendo que geralmente as tentativas de melhora das propriedades físicas esbarram na compatibilidade tecidual dos potenciais cimentos, decidimos revisar a literatura científica pertinente para descobrir o comportamento biológico provável da adição de substâncias radiopacas com e sem hidróxido de cálcio à pasta zinco-enólica na tentativa de melhorar sua performance clínica quando utilizada como cimento retrobturador. 
REVISÃO DA LITERATURA 


\section{REVISÃO DA LITERATURA}

ZUOLO, FERREIRA e GUTMANN ${ }^{17}$ avaliaram em estudo prospectivo, baseados em evidências científicas, o prognóstico das cirurgias periapicais. Para o experimento, selecionaram 102 pacientes com lesão radiográfica apical presente e história de tratamento ou retratamento de canal prévio. Todas os procedimentos de retrobturação, onde empregaram $O$ IRM $\mathbb{R}$ foram executadas por operador único. Os pacientes tiveram as condições clínicas e radiográficas avaliadas, com critérios pré-estabelecidos, por dois examinadores. Os autores encontraram uma taxa de 91,2\% de sucesso clínico-radiográfico após 4 avaliações anuais, e concluíram que a adesão à protocolos cirúrgicos rigorosos e o uso de técnicas e materiais atuais resultam em sucesso previsível na grande maioria dos dentes tratados.

A frase "compatibilidade aos tecidos periapicais" pode ser definida, adaptando-se a definição de HOUAISS, VILLAR E FRANCO ${ }^{49}$, como a capacidade inerente aos materiais retrobturadores, de harmonizarem-se com os tecidos periapicais. Esta característica é alvo de inúmeras pesquisas envolvendo diferentes métodos como culturas de células e tecidos, implantes subcutâneos e intra-ósseos em animais, além de testes de comportamento em animais simulando as condições presentes nos dentes de humanos.

Atualmente, pode-se considerar a compatibilidade biológica de um cimento endodôntico como determinante da aceitação e inserção do mesmo no contexto odontológico. Esta preocupação fundamenta-se no fato de que o sucesso do tratamento 
depende, entre outros fatores, do potencial de irritação do material obturador, tendo em vista o contato deste com os tecidos periodontais até o término do reparo. WENGER et $\mathrm{ll}^{112}$, consideram óbvia a preferência por substâncias obturadoras que estimulam as menores reações inflamatórias.

De acordo com TORABINEJAD et al ${ }^{101}$, as características ideais aos materiais retrobturadores são as mesmas necessárias aos obturadores de canais radiculares A grande maioria dos cimentos retrobturadores utilizados atualmente provieram adaptados de especialidades odontológicas como a dentística e endodontia através de materiais restauradores temporários ou definitivos como amálgama de prata, IRM, Cavit, Lumicon, cimentos de base ionomérica /Vitrebond, Dycal VLC, Vitremer, Ketac Silver), cones de guta-percha e cimentos obturadores de canal radicular, como cimento de Grossman, N-Rickert, cimento de ROHT, e mais recentemente o Sealapex e Sealer 26.

○ amálgama foi empregado como preenchedor de cavidades retrógradas durante décadas, mas as deficiências de vedamento e a liberação de subprodutos da corrosão em meio úmido, estimularam à descontinuidade de seu uso ${ }^{18}$.

A guta percha, um material considerado biocompatível, teve sua resposta tecidual investigada por HOLLAND et al ${ }^{45}$. Cones de diferentes procedências foram implantados no tecido subcutâneo de ratos e, aos 30 e 60 dias, coletou-se os tecidos circundantes, para processamento histotécnico e análise microscópica. Os autores observaram ao redor dos materiais uma cápsula fibrosa circundante formada por fibras colágenas evidenciadas pela coloração de Van Gieson e uma população celular de fibroblastos e macrófagos. Aos 60 dias, o número de fibras colágenas na cápsula era mais freqüente e algumas em contato com o material implantado. Neste período os 
autores também encontraram células gigantes multinucleadas do tipo corpo estranho e linfócitos. A partir dos resultados os autores concluíram que as diferenças de comportamento tecidual eram pequenas e que os mesmos constituem substâncias pouco irritantes ao tecido conjuntivo subcutâneo do rato.

A reação tecidual de subcutâneo de rato à cones de guta percha tradicionais e acrescidos de hidróxido de cálcio (80\%) ou clorofórmio (percentagem não divulgada) também foi avaliada por WOLFSON \& SELTZER ${ }^{114}$. Após 64 dias de permanência das diferentes marcas de cones em contato com os tecidos, a análise microscópica dos espécimes evidenciou à existência de cápsula fibrosa em curso de organização e maturação, além de reação inflamatória do tipo corpo estranho. Ao redor dos cones acrescidos de hidróxido de cálcio uma reação inflamatória moderada foi observada, e naqueles acrescidos de clorofórmio constataram inflamação aguda mesmo após 64 dias.

Todavia, o uso da guta-percha como material retrobturador foi descontinuado devido à ausência de adesão à cavidade e também à desadaptação da interface do material durante o brunimento. Estes transtornos estimularam a busca de materiais dotados de propriedades adesivas á dentina e que, ao mesmo tempo, fossem biocompatíveis.

Os cimentos de ionômero de vidro foram sugeridos como cimentos retrobturadores em decorrência das adequadas propriedades físicas verificadas como restaurador dental, especialmente a ligação química com a matriz dentinária. Em recente revisão de literatura sobre o emprego de cimentos de ionômero de vidro nos tratamento endodônticos convencionais e cirúrgicos, DE BRUYNE e DE MOOR ${ }^{26}$ declararam que, apesar das características críticas de manuseio, existem 
evidencias científicas de que estes cimentos são dotados de um elevado grau de compatibilidade subcutânea e óssea.

PISSIOTIS et al ${ }^{83}$ compararam a reação tecidual óssea produzida por tubos de politetrafluoretileno (Teflon®) preenchidos

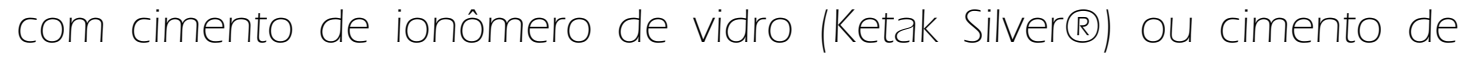
óxido de zinco e eugenol reforçado (SuperEBAR). Os cilindros foram inseridos em lojas cirúrgicas bilaterais nas mandíbulas de 16 porquinhos-da-índia, de forma que a parte inferior permanecesse em contato com a porção medular. Os pesquisadores utilizaram as paredes externas dos tubos como controle para reduzir o número de amostras empregadas. Para a coleta dos tecidos, metade dos animais foi morta após 4 semanas e a outra metade depois de 12 semanas. A análise microscópica foi realizada com auxilio de critérios padronizados como tipos celulares predominantes, caráter da reação inflamatória e espessura do tecido conjuntivo fibroso adjacente ao material. Verificaram, sob as condições do experimento, que o Super EBA produziu reações inflamatórias celulares leves a moderadas no período inicial, e após 12 semanas equiparou-se à inflamação leve associada ao cimento de ionômero de vidro.

CHONG, PITT FORD E KARIYAWASAM ${ }^{20}$ examinaram microscopicamente as respostas teciduais promovidas por um cimento de ionômero de vidro fotoativado (VitrebondR) e um cimento de óxido de zinco e eugenol (Kalzinol@). Amálgama foi o material empregado como controle. Um total de 6 cães tiveram 54 raízes inoculadas por espécies e quantidades iguais de bactérias até que lesões periapicais pudessem ser diagnosticadas radiograficamente. Em cada raiz, realizou-se apicectomia e retro-preparo a ser preenchido com os materiais em teste. Os animais foram mortos decorridas 4 e 8 semanas pós-experimento. Um total de 30 raízes removidas no 
primeiro período e 24 no segundo, passaram por processamento histotécnico para as análises. Com critérios pré-determinados, como extensão da inflamação, células predominantes, presença de cápsula fibrosa, deposição neocementária e bactérias nos canais, dois examinadores procederam às avaliações. Os pesquisadores concluíram que embora o cimento de óxido de zinco e eugenol evidenciasse melhor resposta tecidual na quarta semana e o cimento de ionômero de vidro fotopolimerizável na oitava, ambos materiais mostraram respostas teciduais mais favoráveis que as relacionadas ao amálgama de prata.

$\bigcirc$ óxido de zinco eugenol puro foi desenvolvido inicialmente como cimento restaurador provisório de cavidades coronárias, contudo as extremas exigências a que o material é submetido exigiram a incorporação de novas substâncias de modo a aumentar a resistência a compressão e ao desgaste mastigatório, além de diminuir a solubilidade do mesmo em saliva ${ }^{77}$.

Os materiais, em cuja composição predomina o óxido de zinco e eugenol, foram introduzidos na cirurgia paraendodôntica devido ao endurecimento rápido que facilitara a execução da retroburação na etapa trans-operatória ${ }^{18}$.

$O$ IRM (do inglês Intermediary Restorative Material) foi idealizado pela adição de 20 \% de metacrilato de metila ao pó de óxido de zinco, ambos a serem misturados ao líquido composto por eugenol (99\%) e ácido acético (1\%). Outro restaurador provisório desenvolvido é o EBA alumina ou Super EBA (do inglês 2- Ethoxibenzoic Acid), o qual contém 60\% de óxido de zinco, 34\% de óxido de alumínio e 6\% de resina natural, com o líquido para espatulação sendo constituído de 37,5\% de eugenol e 62,5\% de ácido orto-etóxi benzóico ${ }^{77}$. 
Segundo BRAMANTE e BERBERT ${ }^{13}$, o EBA e o Super EBA possuem boa aderência às paredes da cavidade retrógrada, bom selamento, boa radiopacidade, além de tempo reduzido de endurecimento, o que permite seu brunimento antes do término da cirurgia.

O bom vedamento concedido pelos cimentos á base de óxido de zinco e eugenol é bem estabelecida na literatura 7, 30,25,4,15

CAMPS et al ${ }^{17}$ investigaram os efeitos das diferentes proporções pó/líquido (P/L) nas propriedades físicas dos cimentos obturadores radiculares à base de óxido de zinco e eugenol. Os autores determinaram as três proporções $P / L$ a serem pesquisadas com base nas consistências de trabalho preferidas por 10 endodontistas

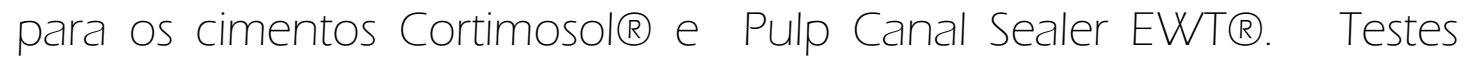
seguindo os padrões da norma 1506876 possibilitaram avaliar propriedades como escoamento, tempo de trabalho, tempo de endurecimento, espessura da película, alterações dimensionais, solubilidade e radiopacidade. Qualidades como grau máximo e mínimo de liberação do eugenol em água e infiltração apical ao corante azul de metileno também foram computadas. A estatística dos dados evidenciou que as influências das variações na relação P/L foram limitadas. variando de acordo com a marca comercial do cimento. aumento da proporção P/L reduziu em 25\% o escoamento dos cimentos, a aumentou em 40\% a radiopacidade e diminuiu em 50\% a quantidade de eugenol liberado. Os cientistas afirmam que essas alterações parecem ser clinicamente irrelevantes, logo os endodontistas podem proporcionar os cimentos de acordo com a técnica de obturação escolhida.

Numa revisão de literatura sobre as propriedades biológicas do óxido de zinco e eugenol, MARKOWITZ et al ${ }^{67}$ defendem 
que os efeitos farmacológicos do mesmo são provavelmente complexos e dependentes da concentração livre desta substância ao qual o tecido é exposto. Mesmo assim, parece óbvio que a quantidade de cimento obturador exposto aos tecidos viáveis deveria ser mínima.

STASHENKO ${ }^{93}$ advoga que o eugenol pode ter um componente imunogênico que desencadearia reações inflamatórias, onde macrófagos, plasmócitos e linfócitos aparecem independente da concentração utilizada no composto.

HUME ${ }^{50}$ assumiu que variações na proporção pó/líquido representam modificações leves na disponibilidade do eugenol nos tecidos. Este mesmo autor, em $1986^{51}$ afirmou que quando o óxido de zinco e eugenol é posto em contato com o tecido conjuntivo, ocorre liberação do mesmo em concentrações suficientes para causar a morte de células.

com a intenção de comparar microscopicamente o processo reparatório ósseo, após apicectomia e obturação retrógrada padrão utilizando SuperEBAR, IRMR, cimento de ionômero de vidro, amálgama ou resina composta, TROPE et al ${ }^{107}$ induziram a formação de lesões periapicais nos dentes de 7 cães, para que os procedimentos cirúrgicos de curetagem, apicectomia e obturação retrógrada, com um dos materiais supracitados, reproduzissem a situação clínica endodôntica. Os canais permaneceram contaminados e nenhum dos mesmos sofreu tratamento endodôntico. $\bigcirc$ grupo controle positivo do experimento era constituido de dentes com cavidade retrógrada sem preenchimento. Depois de 6 meses os cães foram mortos e as peças processadas para análise microscópica. Os pesquisadores avaliaram quantitativamente as medidas das estruturas teciduais, o número de células inflamatórias presentes em cada corte e a condição periapical geral. Os resultados, após análise estatística, atribuíram ao Super EBA e 
o IRM os menores índices de inflamação tecidual. Contudo, segundo os autores, este estudo não permitiu comparar o selamento apical à longo prazo destes materiais com aquele atribuído ao amálgama de prata.

WENGER et al ${ }^{112}$ introduziram, no interior das tíbias de 40 ratos, tubos de polietileno preenchidos completamente em uma das extremidades e parcialmente na outra, com guta percha e cimento tipo Grossman. O grupo controle, constituído de tubos vazios, permaneceu nas tíbias contralaterais até o momento das coletas, aos 3, 7, 30, 60 e 90 dias do experimento. Os autores verificaram a boa tolerância do tecido ósseo relativa aos materiais em teste e ao dispositivo de polietileno, a partir dos 30 dias, expressa na forma de cápsula fibrosa e neoformação óssea, sem interferência dos diferentes níveis das obturações.

OLSEN, AUSTIN e WALIA ${ }^{75}$ investigaram, em ratos Sprague-Dawley, a reação inflamatória intra-óssea aos materiais usualmente empregados como retrobturadores em cirurgias paraendodônticas. Os autores introduziram um tubo de polietileno preenchido com IRM@ (L.D. Caulk) ou cimento EBA® (Teledyne Getz) na porção medular das tíbias de 62 ratos machos. Tubos vazios implantados constituíram o grupo controle negativo, enquanto tubos completos por amálgama (Dispersalloy®) formaram o grupo controle positivo. Em cada um dos períodos estabelecidos, de 7, 14, 21, 56 e 100, um total de quatro animais de cada grupo experimental e um de cada controle foram mortos e processados para análise histológica, executada de forma qualitativa com base em critérios previamente estabelecidos. Os resultados obtidos mostraram que IRM e amálgama apresentaram formação lamelar óssea aos 56 dias, ao passo que o EBA $\circledR^{\circ}$ mostrava ainda resposta inflamatória leve. Entretanto, aos 100 
dias as reações de reparo todos os materiais assemelharam-se. Os pesquisadores concluíram que reações favoráveis foram observadas com ambos materiais à base de óxido de zinco e eugenol.

A reação tecidual medular à três potenciais materiais retrobturadores foi examinada microscopicamente por BHAMBHANI e BOLANOS 5 , que implantaram em cada mandibula de 14 porquinhosda-índia, cimento à base de Teflon (El duPontR), cimento à base de hidróxido de cálcio (VLC Dycal(R) e cimento à base de óxido de zinco e eugenol (IRM®). A guta-percha implantada serviu como grupo controle positivo, enquanto do controle negativo faziam parte sítios cirúrgicos vazios. Após 4 e 12 semanas, os animais foram mortos e as peças processadas para análise microscópica. Os cientistas puderam verificar que a resposta tecidual do IRM assemelhou-se à resposta da guta percha aos 120 dias, caracterizada por cápsula fibrosa delgada circundante e células inflamatórias em pequena quantidade ou ausentes. $\bigcirc$ material à base de teflon exibiu células gigantes associadas em ambos períodos. O cimento à base de hidróxido de cálcio mostrou evidências de encapsulamento fibroso e formação de tecido duro aos 30 dias e aposição direta sobre o cimento aos 120 dias. Considera-se controversa a existência de reparo tecidual periapical quando do uso destes cimentos, cuja compatibilidade tecidual é alvo de inumeráveis pesquisas.

OLSSON, SLIWKOWSKI e LANGELAND ${ }^{76}$ avaliaram a eficácia do método de implante intra-Ósseo em porquinhos-da-índia através da colocação de de receptáculos de Teflon contendo os cimentos endodônticos Kloroperka NØ, tipo Kerr e AH 26. Recipientes vazios foram usados como controle. Cada um dos 24 animais recebeu dois implantes diferentes, e em cada intervalo de 30, 90 e 180 dias pósoperatórios, um grupo aleatório de 8 porquinhos era morto. Os 
fenômenos teciduais observados à luz da microscopia óptica denotaram formação óssea no grupo control já apartir do $30^{\circ}$ dia, ao passo que os grupos experimentais exibiam tecido necrótico, macrófagos e células gigantes multinucleadas do tipo corpo estranho. Aos 90 dias o grupo controle mostrava-se separado do osso por delgada camada de células, enquanto inflamação aguda persistia nos grupos dos cimentos Kloroperka NØ e Kerr. Aos 180 dias, células inflamatórias remanesciam entre o osso e o dispositivo de Teflon, nos grupos experimentais, ao passo que o grupo controle havia sido completamente preenchido por tecido ósseo. Os autores concluíram que a implantação intra-óssea é um método prático para avaliação qualitativa de materiais endodônticos, entretanto quantificações de fenômenos são possíveis somente quando os materiais em estudo possuem acentuadas diferenças de irritabilidade tecidual.

DEEMER e TSAKNIS ${ }^{27}$ pesquisaram a influência do extravasamento de cones de guta percha e cimento de Grossman no tecido medular da tíbia de 48 ratos machos. Para tal, valeram-se de tubos de polietileno para simular condutos radicualres. Tubos vazios nas tíbias contralaterais formavam o grupo controle. Os membros inferiores dos animais foram coletados nos intervalos de 4, 7, 14, 30, 60 e 90 dias pós implantação. Os autores observaram, no grupo experimental, modelamento das fibras e redução da espessura da cápsula fibrosa á medida que o tempo progredia. No grupo controle, o tecido fibroso passou a ser substituídos por tecido ósseo a partir do $14^{\circ}$ dia, até o completo preenchimento aos 90 dias. Os autores demonstraram ser o cimento tipo Grossman, a guta percha e o polietileno, materiais bem tolerados pelos tecidos intra-ósseos do rato e, também o não comprometimento do processo de reparo em virtude do extravasamento de materiais obturadores. 
FRIEND e BROWNE ${ }^{37}$ inseriram, nas tíbias de 24 coelhos, 8 tubos de polietileno, sendo 7 preenchidos inteiramente com um dos materiais experimentais: amálgama de prata (True Dentalloy(), cimento de óxido de zinco e eugenol modificado com formalina (N2®), resina polivinílica (Diaket Normal(B), resina epóxica (AH26®), pasta iodoformada (Kri IR), cimento de óxido de zinco com óleo de cravos e, cimento de fosfato de zinco (SS White®), e por fim o oitavo tubo preenchido com soro fisiológico. Os espécimes permaneceram nos óssos pelos períodos de 2, 7, 14, 28, 90 e 180 dias pós inserção, quando então foram coletados. Os autores observaram, no grupo provido de óxido de zinco e óleo de cravos, que entre 2 e 30 dias, os espécimes eram circundados por tecido fibroso com alguns macrófagos de permeio. Aos 90 e 180 dias, tecido fibroso havia sido substituído por tecido ósseo, mas uma delgada camada de células o separava do polietileno. Já no grupo da pasta iodoformada, verificaram em 30 dias, a mesma cápsula fibrosa relatada para o grupo do óxido de zinco e óleo de cravos, na qual apareciam alguns macrófagos e trabéculas ósseas. As trabéculas ósseas aumentaram de tamanho conforme o transcorrer dos períodos, contudo espaços lacunares de tecido fibroso podiam ser vistos decorridos 180 dias. Interessante ressaltar a presença de grânulos deste material no interior de macrófagos e células gigantes.

HOLLAND et $\mathrm{al}^{43}$ estudaram o comportamento inflamatório existente entre a consistência do cimento obturador e a relação de proximidade desta com os fenômenos inflamatórios eventuais nos tecidos. Para cada variável os autores preencheram 6 tubos de polietileno com um dos materiais (cimentos Fill Canal@, Óxido de zinco e Eugenol®, Trim e Wach®) que foram introduzidos em pares no subcutâneo do dorso de ratos. O grupo controle consistia de tubos 
obturados apenas com cones de guta percha. Decorridos 30 dias do experimento os animais foram mortos e as peças processadas para análise. Os autores verificaram respostas inflamatórias mais intensas nos grupos cujos cimentos possuíam menor relação pó-líquido e estendíam-se até a extremidade dos tubos de polietileno.

As diferenças da resposta inflamatória, do tecido conjuntivo subcutâneo de ratos, em função da quantidade de eugenol empregada no cimento obturador endodôntico Fillcanal \& foram pesquisadas por RAMALHO, SANTANA e RAMALHO ${ }^{85}$. Os cimentos foram espatulados, conforme orientações do fabricante, com três percentagens de líquido reagente na mistura (aproximadamente 47\%, $31 \%$ e 18\%), que foi Imediatamente introduzida em toda extensão dos tubos de polietileno. Tubos vazios constituíam o grupo controle. Cada um dos 20 animais recebeu os 4 implantes distintos em seu dorso. As biópsias dos 4 implantes distintos em cada dorso ocorreram após 3, 7 , 15, 30 e 60 dias das inclusões. Á luz da microscopia óptica, os cientistas avaliaram qualitativamente a resposta inflamatória de acordo com uma escala graduada. Concluiu-se que os cimentos endodônticos à base de óxido de zinco e eugenol foram irritantes em todas as proporções empregadas, no entanto a reação inflamatória de menor intensidade foi verificada junto ao grupo com a menor proporção de eugenol, onde o declínio da inflamação ao longo dos períodos experimentais, mostrou-se significante quando relacionado ao dos demais grupos. Ressaltaram ainda, evidências de reparo tecidual ̀̀ longo prazo, logo um tempo experimental mais extenso poderia ser útil para avaliar o processo inflamatório até a fase final do reparo.

PASCON et al ${ }^{74}$ analisaram microscopicamente as reações inflamatórias resultantes da obturação de 203 dentes de babuínos, a um dos seguintes cimentos: AH26@, KERR Pulp Canal Sealer ${ }^{\circledR}$ e 
Kloropercha N. $\varnothing .^{\circledR}$ Descartaram-se as obturações, através de análise microscópica, que transcendiam o milímetro final do canal dentinário. A coleta dos espécimes aconteceu 1, 7, 30, 365, 730 e 1095 dias após o preenchimento dos canais. Os exames microscópicos dos tecidos periapicais mostraram que no período de 1 dia, a concentração de células inflamatórias foi maior no grupo obturado com cimento a base de óxido de zinco e eugenol. Entretanto, nos períodos 7, 30, 365 dias depois de obturados, visualizou-se a persistência de células inflamatórias crônicas nos três grupos. Aos 2 e 3 anos subseqüentes, uma inflamação periapical crônica, julgada pelos autores como leve, foi observada em todos os espécimes. Os pesquisadores puderam concluir que o estabelecimento rígido de métodos clínicos e microscópicos permite diferenciação entre materiais severamente irritantes e não irritantes, e que é impossível de classificar o grau de inflamação em estágios intermediários.

PASSERI e CARVALHO ${ }^{79}$ compararam, em ratos, a compatibilidade tecidual de condicionadores de tecidos (FITTR, Lynal $\mathbb{R}$ e Visco-gel@| e da pasta zinco-enólica Lysanda® quando em contato com dois tecidos distintos: áreas cruentas do palato e cavidades cirúrgicas na mandíbula. Os animais do primeiro experimento foram mortos decorridos 2 a 15 dias e, as peças da segunda etapa foram coletada de 4 a 30 dias após a implantação. Evidenciaram que a pasta zinco-enólica mostrou-se o material mais irritante entre os materiais testados.

PASSERI et al ${ }^{80}$ realizaram avaliação clínico-microscópica da mucosa bucal de 16 pacientes submetidos à cirurgia excisional e recobrimento da lesão com pasta zinco-enólica (Lysandaß) ou condicionador de tecidos (Lynal(R). Decorridos 7 dias, procederam ao exame clínico, biópsias localizadas e recobrimento das feridas de 8 
pacientes. Aos 15 dias, coletaram amostras teciduais e informações clínicas dos 8 pacientes remanescentes. $\bigcirc$ controle clínico final foi realizado aos 21 dias. Dentro dos limites impostos pelas condições experimentais, os autores observaram organização precoce dos feixes de fibras colágenas nos grupos onde o condicionador havia sido aplicado, diferentemente daqueles associados à pasta zinco-enólica, onde grau acentuado de infiltrado inflamatório estava presente.

$O$ pioneiro na pesquisa da pasta zinco-enólica como material retrobturador foi BERNARDINELI ${ }^{7}$ que avaliou a correlação entre a adaptação às paredes de cavidades retrógradas, e infiltração marginal de oito materiais utilizados nos diversos segmentos da odontologia, em função de diferentes agentes de limpeza. Para o experimento empregou 180 dentes extraídos, divididos em 18 grupos diferentes, cujos ápices foram seccionados para o preparo das retrocavidades que tiveram seu interior irrigado com uma das soluções (solução fisiológica; hipoclorito de sódio a 1\% e solução fisiológica; EDTA e solução fisiológical antes de receberem um os materiais retrobturadores pesquisados (Pasta Lysanda $₫$, cimento Coe Pack $®$, cimento de ionômero de vidro Chelon Silver $®$, cimento Super EBA®, cimento N-Rickert巴 e cimento de hidróxido de cálcio fotopolimerizável Renew (B) de forma que todas as soluções irrigadoras e os materiais se correspondessem. Obteve-se a análise dos dados por intermédio de microscópio eletrônico de varredura e microscópio óptico. A pasta zinco-enólica Lysanda $\circledR$ e o ionômero fotopolimerizável Renew ${ }^{\circledR}$ apresentaram os menores índices de infiltração marginal e desajuste

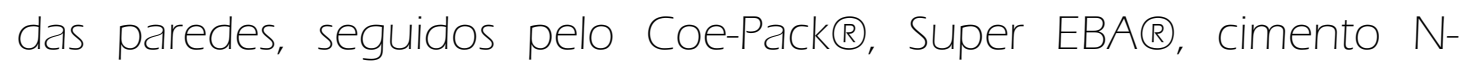
Rickert $\AA$ e cimento Chelon Silver $\AA$. O autor conclui que a possivel correlação entre desajuste e infiltração marginal mostrou-se estatisticamente positiva quando do uso da solução fisiológica como 
agente de limpeza, negativa quando do emprego da solução de Milton e não muito bem definida em relação ao EDTA, mostrando uma tendência não muito bem evidenciada de que quanto maior o desajuste maior a infiltração.

DUTRA $^{29}$ pesquisou "in vivo" a capacidade da pasta Lysanda® em impedir a penetração de fluídos quando aplicada como material retrobturador. O pesquisador comparou-a ao amalgama em 20 dentes segundos e terceiros incisivos de 10 cães sobre os quais realizaram-se cirurgias paraendodônticas do tipo apicectomia e obturações retrógradas. Passado o período de 30 dias, os animais foram mortos e os dentes extraídos. Após impermeabilização das raízes com Araldite $®$, imergiu-se os espécimes em corante azul de metileno a $2 \%$, dentro de estufa a $37^{\circ} \mathrm{C}$, por uma semana. Os dentes foram posteriormente seccionados no longo eixo para que os níveis de infiltração de cada material pudessem ser lidos constituindo os dados para análise estatística. Os autores verificaram que a pasta Lysanda® apresentou índices de infiltração ausentes e moderados, ao passo que o amálgama mostrou graus intensos de penetração do corante.

CUSTÓDIO 24 comparou "in vitro" o vedamento de obturações retrógradas efetuadas a partir de três materiais odontológicos restauradores e um material de moldagem. Quarenta dentes caninos humanos extraídos, divididos em 4 grupos tiveram seus respectivos ápices seccionados para que cavidades retrógradas fossem uniformizadas e preenchidas por um dos quatro materiais: Grupo 1 amálgama de prata sem zinco; Grupo 2 - cimento de ionômero de vidro; Grupo 3 - Resina composta e adesivo dentinário e Grupo 4 pasta zinco-enólica Lysanda®. Em seguida, após impermeabilização das raízes, imergiu-se as amostras em corante de azul de metileno a 2\%, à temperatura de $37^{\circ} \mathrm{C}$, por 60 horas. $\bigcirc$ corte longitudinal dos 
espécimes possibilitou a leitura, em microscópio óptico, dos graus de infiltração marginal na interface entre cada um dos materiais e a dentina. A análise de variância dos dados mostrou que o grupo da pasta de impressão zinco-enólica apresentou os menores índices de infiltração apical em relação aos outros materias testados.

MORAIS ${ }^{71}$ estudou, em subcutâneo de ratos, a biocompatibilidade dos cimentos Pro RootR, tipo Portland acrescido de iodofórmioß e pasta de impressão Lysanda®. Empregou para tal tubos de polietileno preenchidos com os materiais no dorso de 18 ratos machos da linhagem Wistar (Ratus Norvegicus Albinus) divididos em 4 grupos de 6 animais para cada período experimental. Tubos vazios também foram implantados como controle. Os animais foram mortos nos períodos de 7, 30 e 60 dias após a cirurgia de inclusão dos cimentos. Os resultados obtidos com o auxílio de microscopia óptica revelaram que, os 3 cimentos tinham, de um modo geral, comportamentos semelhantes aos 7 e aos 30 dias, mas que aos 60 dias, a pasta Lysandå produziu uma resposta inflamatória crônica semelhante ao grupo controle e equivalente à metade daquela

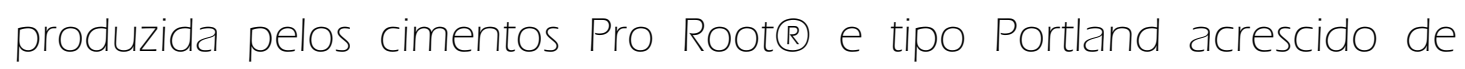
iodofórmioß).

Desde a descoberta do trióxido mineral agregado várias usos foram dados a este material, no entanto, segundo LEE et al ${ }^{62}$, o mesmo foi produzido para preencher cavidades retrógradas nas cirurgias paraendodônticas e selar comunicações entre o meio interno e externo do dente. Ao trióxido mineral agregado é atribuído índice inferior de infiltração por corante e bactérias, quando comparado com Super EBA, IRM e amálgama ${ }^{62,100,4,68,66}$, além de baixa toxicidade tecidual e estímulo da deposição de tecido duro. 
A citotoxicidade de quatro potenciais produtos retrobturadores (amálgama, trióxido mineral agregado, restaurador provisório à base de óxido de zinco e eugenol - IRM® , e Super EBA) foi testada "in vitro" por TORABINEJAD et al ${ }^{101}$. Os cimentos, inseridos cada qual em 20 tubos de polietileno, permaneceram em contato, em estufa, por 4 e 24h, com fibroblastos L929 marcados com cromato de sódio. Ao fim do experimento avaliou-se a percentagem de $51 \mathrm{Cr}$ liberado, pós-centrifugação, nos tubos de ensaio. Os resultados indicaram que trióxido mineral agregado foi o menos tóxico dos materiais, seguido pelo amálgama, Super EBA e IRM®.

As reações teciduais intra-ósseas ao super-EBA e agregado de trióxido mineral foram investigadas por TORABINEJAD et $\mathrm{al}^{102}$. Para o estudo, os autores preencheram tubos de Teflon com ambos os materiais e os implantaram na sínfise mentoniana de 6 porquinhos-da-índia, permanecendo neste sítio até o momento da coleta, ao término de 8 semanas. O grupo controle era constituido por cavidades ósseas vazias. Após o processamento histotécnico e durante a análise microscópica os autores observaram que o tecido conjuntivo fibroso adjacente ao Super-EBA mostrava-se mais espesso que o associado ao MTA e, verificaram também, a presença de osso neoformado próximo somente a uma das 5 amostras de agregado trióxido mineral. Baseados no estudo, os pesquisadores concluíram que tanto o Super-EBA quanto o MTA parecem ser biocompatíveis.

TORABINEJAD, et al ${ }^{103}$ compararam as respostas teciduais provocadas pelo trióxido mineral agregado (Loma Linda University CA) e amálgama de prata sem zinco (Kerrr Manufacturing CO) em tecidos periapicais de cães. Após induzirem Lesões radiolúcidas periapicais pela exposição das câmaras pulpares aos meio ambiente oral, os dentes tiveram os canais aleatoriamente divididos em dois 
grupos para que fossem instrumentados e obturados com guta-percha e cimento de Roth ou somente guta-percha. Passadas duas semanas, através dos acessos cirúrgicos, procedeu-se à apicectomia, confecção da cavidade retrógrada com broca tipo cone-invertido e preenchimento das mesmas com os materiais em estudo. A morte programada dos animais seguida do processamento para análise microscópica aconteceu entre 2 e 5 semanas das cirurgias para metade dos cães e 10 a 18 semanas para o restante. Os exames dos cortes histológicos revelaram, no período inicial, uma inflamação severa adjacente ao amálgama de prata, diferente daquela observada com o trióxido mineral agregado. Do mesmo modo, no período final, denotaram formação de cápsula fibrosa e neoformação cementária recobrindo a grande maioria das raízes retrobturadas com MTA, achados não observados nas adjacências do material metálico.

TORABINEJAD et al ${ }^{104}$ al avaliaram a reação tecidual intraóssea aos 80 dias de materiais freqüentemente empregados como retrobturadores: trióxido mineral agregado (MTA $\cap)$, SuperEBAR, material restaurador intermediário (IRM®) e amálgama. Os pesquisadores introduziram tubos de politetrafluoretileno, preenchidos com um dos materiais, nas duas tíbias e em dois sítios da mandíbula de cada um dos 20 porquinhos-da-india. Depois de mortos os animais, as peças passaram por processamento histotécnico para que pudessem ser examinadas por dois profissionais sem conhecimento dos materiais investigados. Os cálculos estatísticos não indicaram diferença entre os dois locais utilizados para os implantes, mas apontaram uma reação tecidual mais favorável ao trióxido mineral agregado, com ausência de inflamação,, seguido de Super-EBA e IRM, intermediários, e amálgama com os maiores sinais de inflamação adjacente e persistente. 
CHONG, PITT FORD e HUDSON ${ }^{21}$ avaliaram a taxa de sucesso associada às retrobturações executadas aleatoriamente com trióxido mineral agregado (Pro Root@ - Dentsply) e material restaurador intermediário (IRM@ - Dentsply). Neste estudo prospectivo, os autores realizaram procedimentos técnico-cirúrgicos padronizados em 122 pacientes criteriosamente selecionados, os quais tiveram o sítio cirúrgico proservado radiograficamene aos 0, 2 e 24 meses póscirurgia. Obtiveram os dados para análise estatística a partir do julgamento qualitativo das radiografias por dois examinadores treinados em com critério alto de concordância inter e intraobservadores. Verificou-se melhores resultados associados às retrobturações onde o trióxido mineral agregado havia sido empregado, no entanto o teste qui-quadrado não apontou diferenças significantes entre os dois materiais. Ainda, a taxa de sucesso presente no controle de 24 meses mostrou-se superior à taxa de 12 meses, tendo o IRM, neste período, aumento de 10\% do índice de sucesso em comparação ao MTA.

MORETTON et al ${ }^{72}$ compararam as reações inflamatórias e potencial osteo-indutor dos cimentos trióxido mineral agregado e EBA, quando inseridos antes e após a presa, na calvária e no subcutâneo de ratos. Um total de 60 ratos foi dividido em dois grupos experimentais de 30 animais, cada qual portava 4 implantes, dois na calvária e dois em subcutâneio. As variáveis eram o tipo de cimento e o tempo decorrido da espatulação. Anterior aos períodos de morte programada dos animais (15, 30 e 60 dias), um marcador de tecidos duros era injetado no peritônio dos ratos. As lâminas confeccionadas foram analisadas qualitativamente quanto ao grau de inflamação baseado no número e tipo de células presente no tecido e quanto à presença de calcificações distróficas e necrose de coagulação. Os 
autores averiguaram respostas inflamatórias iniciais severas e moderadas relacionadas respectivamente ao MTA e EBA declinaram para grau moderado aos 60 dias do experimento, revelando zonas de fibrose e encapsulamento. Ainda, não haviam evidências de osteogênese adjacente a ambos materiais implantados em subcutâneo, em nenhum dos períodos estudados. Contudo, nos implantes intraósseos, a magnitude das respostas inflamatórias mostrou-se comparativamente menor, enquanto a osteogênese estava presente em proporção direta aos períodos, em ambos materiais.

YALTIRIK et al ${ }^{115}$ investigaram em tecido subcutâneo de ratos, as características microscópicas geradas por de tubos de polietileno preenchidos com trióxido mineral agregado (ProRoot巴)), amálgama com alto teor de zinco (Colteneß) ou tubos vazios (grupo controle). Os cilindros foram introduzidos no dorso de 30 ratos da linhagem Wistar, os quais foram mortos em grupos de 6 nos períodos de 7, 15, 30, 60 e 90 dias após as cirurgias. As análises microscópicas dos espécimes evidenciaram que as reações inflamatórias moderadas associadas a ambos materiais decresceram aos 60 dias e mais ainda aos 90, quando foram envoltas por tecido conjuntivo fibroso espesso. Concluíram que as respostas inflamatórias induzidas pelos dois materiais foram favoráveis aos 90 dias. Ainda, os pesquisadores notaram a existência de calcificações distróficas adjacentes aos tubos preenchidos com trióxido mineral agregado, o que poderia evidenciar um efeito indutor de calcificação dos tecidos.

A resposta do tecido subcutâneo de ratos ao implante de tubos de dentina preenchidos com trióxido mineral agregado, cimento Portland e hidróxido de cálcio foi avaliada por HOLLAND et al ${ }^{47}$. Para o controle empregaram 10 animais os quais portaram tubos vazios. Coletaram as peças após 7 e 30 dias pós-cirúrgicos. A análise 
microscópica dos cortes, após processados pelo método HE e Von Kossa para deposições cálcicas, revelaram presença de inflamação crônica moderada para todos os espécimes independente do período estudados. A análise através de cálculos estatísticos não detectou diferenças significantes entre os três materiais. Os pesquisadores destacam a presença de granulações birefringentes à luz polarizada observadas em todas as amostras. Os autores sugerem que o óxido de cálcio contido no MTA e possivelmente também no cimento Portland, ao entrar em contato com os fluídos teciduais, reaja convertendo-se e hidróxido de cálcio, possuindo ambos materiais o mesmo mecanismo de indução da neoformação de tecido duro.

HOLLAND et al ${ }^{48}$ examinaram a deposição de sais de cálcio, em tecido subcutâneo de ratos, associada à implantação de tubos de dentina preenchidos com materiais endodônticos que contêm hidróxido de cálcio (CRCS®, Sealer26®) ou óxido de cálcio (Sealapex®, Pro Root@, Sealer Plus $®$ ) em suas respectivas composições. Tubos de dentina vazios constituíam o grupo controle. Os animais foram mortos nos períodos de 7 e 30 dias, e os tecidos preparados pelo método de Von Kossa para análise microscópica empregando a luz polarizada. Os pesquisadores denotaram existência de estruturas calcificadas birefringentes à luz polarizada adjacentes à todos os materiais estudados, já no período de 7 dias, com exceção do CRCS que revelou uma camada de exsudato e neutrófilos ao redor do material aos 7 dias, infiltrado inflamatório crônico moderado e fibroblastos jovens aos 30 dias. Os autores aventam a possibilidade de que a ocorrência de tecido mineralizado tenha alguma relação com a presença de íons cálcio liberados dos materiais e que a interação química dos mesmos com o eugenol, no caso do cimento CRCS, tenha inibido a propriedade osteo-indutora deste cimento. 
OLIVEIRA ${ }^{74}$ pesquisou as reações inflamatórias resultantes da mistura do cimento endodôntico AH-26 e pó de hidróxido de cálcio adicionado nas proporções de 5, 10, 20 e 40\%. Os grupos controle eram formados por cimento AH-26 puro (positivo) e pasta de hidróxido de cálcio em veículo aquoso (negativo). Os tubos de polietileno contendo os materiais eram inseridos, pelo sistema de rodízio, no subcutâneo de 18 ratos. Nos períodos de 8, 30 e 60 dias os animais foram mortos e as peças processadas para análise microscópica. 0 autor determinou a seguinte ordem decrescente de inflamação tecidual: pasta aquosa de hidróxido de cálcio, cimento AH 26 com hidróxido de cálcio nas proporções de 5, 20 e 40\% respectivamente e por fim o cimento $\mathrm{AH}-26$ puro ou acrescido de 10 de hidróxido de cálcio.

BERBERT ${ }^{6}$ estudou, através da análise por microscópica óptica, o comportamento inflamatório manifesto nos tecidos periapicais de cães quando da obturação, após biopulpectomia, dos canais com cones de guta-percha associados ao cimento AH-26 adicionado de hidróxido de cálcio nas proporções de 5 e 20\%. Os grupos controle eram formados por cimento AH-26 puro (positivo) e pasta de hidróxido de cálcio em veículo aquoso (negativo). Cada animal, 16 no total, recebeu cada uma das substâncias dentro de quatro pré-molares. Os animais foram sacrificados aos 7, 30, 70-90 e 180 dias após as intervenções. $\bigcirc$ autor encontrou, entre outros achados, relação inversa entre a inflamação presente e o conteúdo de hidróxido de cálcio em todos os materiais. Ainda, a formação de barreira apical mostrou-se diretamente proporcional ao aumento da proporção do hidróxido de cálcio e períodos pós-operatórios. Por fim, a formação de barreira por hiperplasia cementária só ocorreu nitidamente ante a pasta 
aquosa de hidróxido de cálcio ou ante o AH26 acrescido de 20\% de hidróxido de cálcio.

WALTIMO ${ }^{109}$ pesquisaram, através de análise clínicoradiográfica, em estudo prospectivo, os efeitos da incorporação de hidróxido de cálcio aos cimentos endodônticos. Um total de 204 dentes, selecionados para o estudo, tiveram o conduto radicular instrumentado e obturado, por alunos de graduação, com um dos três cimentos (Sealapex $R$, CRCSR ou ProcosolR). Os resultados dos tratamentos nos pacientes foram acompanhados anualmente durante 4 anos. A análise da situação periapical de cada dente foi realizada por um examinador, desinformado do cimento empregado, que atribuiu uma pontuação de acordo com um sistema de índice periapical. $\bigcirc$ processamento estatístico dos dados quantitativos permitiu aos autores concluírem que o reparo de dentes portadores de periodontites apicais

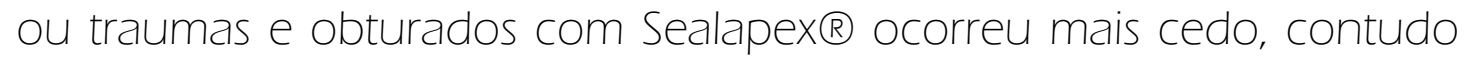
após três anos não houve diferença estatística em relação aos cimentos de óxido de zinco e eugenol dotados ou não de hidróxido de cálcio e aquele baseado em salicilato resinoso.

Segundo TAVANO ${ }^{98}$ um agente radiopacificador deveria ter um peso atômico superior ao do cálcio para finalidades radiográficas. Estas substâncias são adicionadas aos materiais para auxiliar na determinação radiográfica dos mesmos nos canais radiculares, auxiliando na localização das obturações, canais laterais e acessórios, fraturas radiculares, desenvolvimento apical, diagnóstico de reabsorções radiculares entre outras patologias. Alguns sais de metais pesados como o bário e bismuto e compostos contendo iodo e bromo são opacos aos raios $X$.

GOMES DE MORAES, TAVANO e BERBERT ${ }^{39}$ aO pesquisarem a radiopacidade de materiais obturadores de canal 
radicular e descobriram que o óxido de zinco não chegou a ser um radiopacificador ideal quando comparado com o padrão aditado pelos cones de guta-percha testados (Maillefer ${ }^{R}$ e Dentsply ${ }^{R}$ ). Os autores afirmam que a radiopacidade deficiente do cimento deixará impressão de falhas na obturação em decorrência do contraste acentuado entre o mesmo e os cones de guta percha.

Um problema com a radiopacidade dos cimentos retrobturadores pode surgir em decorrência das pequenas quantidades destes materiais utilizadas. Em uma radiografia pós operatória, é necessário avaliar se o composto permanece dentro da retrocavidade, bem condensado e sem defeitos, diferenciado da dentina e do cimento obturador do canal radicular. Estes requisitos levaram SHAH Et al (1996) a avaliar o grau de obstrução à passagem dos feixes de raios $X$, proporcionado por substâncias restauradoras (amálgama, Kalzinol@, IRMR, SuperEBAR, VitrebondR, Fuji \|I LCR, Chemfil e guta-percha) utilizadas como retrobturadores. Depois da mistura das mesmas, conforme as especificações dos fabricantes, preencheu-se completamente 5 anéis metálicos com cada uma, totalizando 45 anéis padronizados, $(10 \times 1 \mathrm{~mm}$ em seu interior), que após distribuidos sobre películas radiográficas oclusais foram radiografados juntamente com um penetrômetro de alumínio. Obtiveram os dados numéricos por três leituras com ajuda de um densitômetro fotográfico. Em seguida transformaram-se as médias relativas à cada material em milímetros de alumínio correspondentes. Os autores constataram que somente o amálgama, a guta-percha e os cimentos de óxido de zinco e eugenol situaram-se acima do grau mínimo de radiopacidade (ordem decrescente) estabelecido pela resolução 150 6376. Declaram ainda que a superimposição das trabéculas ósseas e variabilidade na mineralização da dentina dificultam 
o discernimento radiográfico de materiais com radiopacidade equivalente a 3-mm de espessura do alumínio, considerado aceitável pela ISO.

TAGGER e KATZ ${ }^{95}$ submeteram 14 potenciais materiais retrobturadores, à exames comparativos do grau de radiopacidade, na tentativa de estabelecer a conveniência da especificação estabelecida pela norma ISO 6876 para os cimentos obturadores de canal radicular. Os grupos das amostras incluíam cimentos de óxido de zinco e eugenol puros ou aditivados, cimentos de ionômero de vidro, compômeros, trióxido mineral agregado sem radiopacificador, amálgama e resinas compostas. Guta percha em bastão foi utilizada como grupo controle. Os corpos de prova ( $n=3$ ) foram radiografados ao lado de um penetrômetro de alumínio, e as imagens obtidas digitalizadas para quantificação dos pixels nas escalas de cinza. O grau de penetrabilidade à radiação $X$ de cada material foi convertido em milímetros de alumínio. Descobriu-se que as resinas compostas, os cimentos de ionômero de vidro e os compômeros são inaceitáveis como retrobturadores, na categoria radiopacidade. Os autores verificaram também a inexistência de um padrão específico de radiopacidade para os materiais obturadores retrógrados.

BODANEZI e BERNARDINELI ${ }^{9}$ investigaram a potencialidade de substâncias químicas usualmente empregadas na terapêutica endodôntica (subnitrato de bismuto, óxido de zinco, iodofórmio e sulfato de bário) como agentes radiopaicificadores da pasta zinco-enólica $\left(L S^{\circledR}\right)$, quando adicionados em cinco proporçoes diferentes (15, 17.5, 20, 22,5 e 25\%). Anéis metálicos (13×2mm interior) foram preenchidos, com as substâncias devidamente espatuladas após pesagem (acurácia 0,0001g) e proporcionamento dos materiais. Aguardada a presa final, (10min) distribuiu-se cada grupo de anéis 
( $n=20)$, em ordem crescente de proporções, sobre uma das 5 películas oclusais (Ektaspeed Plus), juntamente com 5 anéis de cada grupo controle formado por guta-percha de cones secundários /controle positivo) e pasta zinco-enólica pura (controle negativo). A sensibilização dos conjuntos sobre os filmes radiográficos aconteceu pela emissão de raios $X$ durante $0.45(70 \mathrm{KV} / 6 \mathrm{~mA})$ a uma distância padrão de $40 \mathrm{~cm}$ do colimador do aparelho (Siemens ${ }^{\circledR}$ ). Após revelação padronizada, as imagens obtidas passaram por digitalização fotográfica para que os valores a serem submetidos à analise estatística fossem quantificados. As diferenças estatísticas significantes foram reveladas pela análise de variância (ANOVA) e complementadas pelo Teste de TUKEY ( $P=0.05)$. Pode-se observar que o subnitrato de bismuto e o iodofórmio apresentaram os melhores resultados com as menores concentrações, seguidos pelo sulfato de bário e óxido de zinco. Todas as substâncias, exceto o sulfato de bário a 15\%, produziram contrastes radiográficos aceitáveis.

- comportamento inflamatório dos tecidos frente às substâncias radiopacificadoras puras ou adicionadas a cimentos endodônticos é objeto de estudo desde que a radiologia foi concebida como meio auxiliar de diagnóstico.

Sais insolúveis derivados do bismuto foram usados, como coadjuvantes nos exames radiográficos do trato gastro-intestinal, antes da introdução do sulfato de bário em 1910, atualmente preterido por ser mais barato e menos tóxico, mesmo em altas concentrações. 0 óxido de bismuto ainda aparece na formulação do cimento obturador de canal AH26 e o subnitrato de bismuto na composição do Endomethásone, juntamente com o sulfato de bário, nas concentrações de $26,6 \%{ }^{94}$. 
CARVALHO et al ${ }^{19}$ estudando os efeitos do subnitrato de bismuto no trato gastro-intestinal de humanos, afirmam ter o mesmo influência benéfica sobre a cicatrização de úlceras pépticas.

FAVA e SAUNDERS ${ }^{34}$ afirmam ter os sais de bismuto algum grau de toxicidade enquanto os sais de bário mostram-se extremamente tóxicos e relativamente insolúveis, sugerindo a opção por uma substância radiopaca mais solúvel.

A incapacidade do organismo em reabsorver completamente o sulfato de bário deve-se em parte á sua relativa insolubilidade. Uma alternativa seria a adoção de compostos contendo iodo, entretanto segundo ALAÇAM', uma solução à base de iodo misturada com hidróxido de cálcio seria extremamente irritante se extravasada nos tecidos periodontais apicais.

O iodofórmio teve sua introdução na endodontia em 1928 por WALKHOFF para conferir poder antisséptico à uma pasta empregada no tratamento dos canais de difícil acesso ${ }^{31}$, devido ao seu uso como antisséptico em medicina e à necessidade de controle bactérias recém descobertas como agentes causadores e perpetuadores das periodontites apicais. Diversas foram as formulações de medicamentos intracanais propostas que continham o iodofórmio em suas composições. O iodofórmio foi adicionado ao hidróxido de cálcio com a finalidade de melhorar as propriedades físicas do mesmo, ao conferir maior radiopacidade e efeitos antissépticos, sem interferir na propriedade indutora de calcificação ${ }^{49}$. Considerado irritante leve dos tecidos, o iodofórmio estimula reação inflamatória imediata e breve ว० contato com tecido conjuntivo ${ }^{52}$. HOLLAND et $\mathrm{al}^{46}$, em 1990, investigaram em cães, O comportamento dos tecidos periapicais frente à obturação com o cimento Sealapex puro e acrescido de iodofórmio, nas quantidades de 
30 e 112 miligramas, no intuito de melhorar o aspecto radiográfico daquele cimento. Decorrido o período experimental de 6 meses, os cães foram mortos e os blocos apicais coletados e processados para análise microscópica. Os autores observaram fechamento apical por deposição de tecido duro e não detectaram interferências decorrentes do acréscimo de iodofórmio, independente da proporção agregada.

O hidróxido de cálcio associado ao iodofórmio e à metilcelulose foi analisado por MAISTO \& EURASOUIM ${ }^{64}$, em 1965, ao realizarem obturações em molares de ratos. Os exames microscópicos dos tecidos periapicais evidenciaram junto à pasta um acúmulo de polimorfonucleares neutrófilos que ia diminuindo até o $30^{\circ}$ dia. Ao fim de 60 dias o infiltrado inflamatório era escasso, ocorrendo uma esclerose óssea periapical.

HOLLAND et al $^{46}$ pesquisaram o comportamento dos tecidos periapicais de dentes de dois cães quando da obturação dos

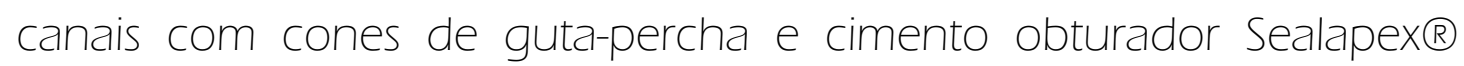
puro ou acrescido de iodofórmio nas proporções aproximadas de 16,6\% e 42,7\%. A análise microscópica das amostras decorridos 6 meses das obturações, denotou deposição de cemento total ou parcial nos ápices de todos os dentes estudados, não havendo diferenças significativas entre os grupos. Concluiu-se que o acréscimo de iodofórmio ao Sealapex, em pequena ou grande quantidade, não modifica as propriedades biológicas deste cimento.

KUGA, MORAES E BERBERT ${ }^{59}$ avaliaram a influência da adição do iodofórmio na capacidade seladora do cimento Sealapex®. O teste de infiltração com azul de metileno a 2\% mostrou que a adição do iodofómio permitiu menores infiltrações que o cimento original e que os menores índices de infiltração apareceram quando 33\% em peso do pó de iodofórmio era adicionado ao cimento puro. 
BERNARDINELI ${ }^{8}$ observou, através de microscopia eletrônica de varredura, que a adição de iodofórmio á pasta Lysanda ${ }^{\circledR}$ não interfere na adaptação marginal do material à cavidade retrógrada.

Na tentativa de criar um cimento que reúna as propriedades de adesividade às paredes da cavidade, compatibilidade tecidual, contraste radiográfico, facilidade de manipulação e aquisição, adicionamos agentes radiopacificadores e hidróxido de cálcio à pasta zinco-enólica e decidimos testá-la microscopicamente em contato com o tecido medular de ratos, a fim de ver os fenômenos teciduais resultantes. 
PROPOSICÃO 


\section{PROPOSIÇÃO}

Investigar microscopicamente a reação inflamatória e o reparo osteomedular de ratos, quando da presença do agregado de trióxido mineral e quando da presença de pasta zinco-enólica acrescida de substâncias radiopacificadoras (iodofórmio ou subnitrato de bismuto) e adicionada ou não de hidróxido de cálcio. 
A ciência, tal como a arte, não é uma cópia da natureza, mas uma recriação da mesma.

Jacob Bronowski

\section{MATERIAL E MÉTODOS}




\section{MATERIAL E MÉTODOS}

\subsection{Composição dos Materiais}

Para este estudo experimental foram utilizados um cimento reparador e uma pasta, à qual adicionou-se substâncias capazes de conferir radiopacidade e possivelmente melhorar suas propriedades biológicas.

Os materiais empregados, assim como suas formulações químicas e respectivas proporções são especificados nas seguintes tabelas:

Tabela 1 - Formula da pasta zinco-enólica $L S^{\circledR}$ tipo II*

$\begin{array}{lc}\text { Composição } & \text { Proporção } \\ \text { Óxido de zinco, óleo de algodão, vaselina, ácido } & 89,75 \% \\ \text { graxo de linhaça, parafina, resina poly-pale } & \\ \text { Eugenol } & 10,25 \%\end{array}$

Tabela 2 - Fórmula do cimento reparador MTA ${ }^{\circledR} * *$

\section{Composição}

$\mathrm{SiO}_{2}, \mathrm{~K}_{2} \mathrm{O}, \mathrm{AL}_{2} \mathrm{O}_{3}, \mathrm{Na}_{2} \mathrm{O}, \mathrm{Fe}_{2} \mathrm{O}_{3}, \mathrm{SO}_{3}, \mathrm{CaO}, \mathrm{MgO}$

(cimento Portland)

Óxido de bismuto $\left(\mathrm{Bi}_{2} \mathrm{O}_{3}\right)$
Proporção

$80 \%$

$20 \%$

Tabela 3 - Fórmula do iodofórmio

Composição

$\mathrm{CH}_{3} \mathrm{l}$
Proporção

99\%

* Vigodent S/A - Rio de Janeiro RJ

** Angelus - Londrina PR

$* * *$ Iodon S/A - Porto Alegre RS 
Tabela 4 - Fórmula do subnitrato de bismuto ****

Composição

Proporção

$\mathrm{Bi}$

$71 \%$

$\mathrm{NH}_{4}, \mathrm{Ag}, \mathrm{As}, \mathrm{Ca}, \mathrm{Cu}, \mathrm{Fe}, \mathrm{Pb}, \mathrm{Zn}, \mathrm{Cl}, \mathrm{SO}_{4}, \mathrm{H}_{2} \mathrm{~S}$

$0,031 \%$

Tabela 5 - Fórmula do hidróxido de cálcio P.A.

Composição

Proporção

$\mathrm{Ca}(\mathrm{OH})_{2}$

$99 \%$

Tabela 6 - Fórmula da Glicerina Líquida*

Composição

Proporção

$\mathrm{C}_{3} \mathrm{H}_{5}(\mathrm{OH})_{3}$

$100 \%$

\section{Proporcionamento das Substâncias}

Da mistura da pasta com uma das substâncias radiopacificadoras, adicionando-se ou não o hidróxido de cálcio, produzimos quatro grupos experimentais de composições e proporções distintas, discriminadas nos quadros abaixo. As constituições do quinto grupo e grupo controle são descritas na sequência.

Tabela 7 - Composição do cimento utilizado no grupo 1

$\begin{array}{ccc}\text { GRUPO } 1 & \text { Ouantidade } & \text { Proporção } \\ \text { Pasta base LS (branca) } & 0,25 \mathrm{~g} & 42 \% \\ \text { Pasta catalisadora LS (vermelha) } & 0,19 \mathrm{~g} & 33 \% \\ \text { Iodofórmio (pó) } & 0,12 \mathrm{~g} & 20 \% \\ \text { Glicerina } & 0,03 \mathrm{~g} & 5 \%\end{array}$

$\star * * *$ Vetec Química Fina LTDA - Rio de Janeiro RJ

$* * * * *$ Biodinâmica - Ibiporã PR

****** Pharmácia Specífica - Bauru SP 
Tabela 8 - Composição do cimento utilizado no grupo 2

$\begin{array}{ccc}\text { GRUPO 2 } & \text { Quantidade } & \text { Proporção } \\ \text { Pasta base LS (branca) } & 0,259 & 42 \% \\ \text { Pasta catalisadora LS (vermelha) } & 0,199 & 33 \% \\ \text { Subnitrato de Bismuto (pó) } & 0,129 & 20 \% \\ \text { Glicerina } & 0,039 & 5 \%\end{array}$

Tabela 9 - Composição do cimento utilliizado no grupo 3

$\begin{array}{ccc}\text { GRUPO 3 } & \text { Quantidade } & \text { Proporção } \\ \text { Pasta base LS (branca) } & 0,259 & 31 \% \\ \text { Pasta catalisadora LS (vermelha) } & 0,19 \mathrm{~g} & 25 \% \\ \text { Iodofórmio (pó) } & 0,159 & 20 \% \\ \text { Glicerina } & 0,039 & 4 \% \\ \text { Hidróxido de cálcio P.A (pó) } & 0,159 & 20 \%\end{array}$

Tabela 10 - Composição do cimento utilizado no grupo 4

$\begin{array}{ccc}\text { GRUPO } 4 & \text { Quantidade } & \text { Proporção } \\ \text { Pasta base LS (branca) } & 0,25 \mathrm{~g} & 31 \% \\ \text { Pasta catalisadora LS (vermelha) } & 0,19 \mathrm{~g} & 25 \% \\ \text { Subnitrato de Bismuto (pó) } & 0,15 \mathrm{~g} & 20 \% \\ \text { Glicerina } & 0,03 \mathrm{~g} & 4 \% \\ \text { Hidróxido de cálcio P.A (pó) } & 0,15 \mathrm{~g} & 20 \%\end{array}$

Tabela 11 - Composição do cimento utilizado no grupo 5

$\begin{array}{ccc}\text { GRUPO } 5 & \text { Quantidade } & \text { Proporção } \\ \text { Cimento reparador MTA }{ }^{\circledR} & 0,15 \mathrm{~g} & 75 \% \\ \text { Agua Destilada } & 0,5 \mathrm{ml} & 25 \%\end{array}$

Tabela 12 - Composição dos tubos vazios utilizados no grupo controle

\begin{tabular}{ccc|}
\hline GRUPO Controle & Quantidade & Proporção \\
\hline Cloreto de polivinila (P.V.C) & não especific. & não especific. \\
Silicone & não especific. & não especific.
\end{tabular}




\section{A medida que cada constituinte dos grupos} experimentais era pesado em balança de precisão AT 261 DeltaRange®* (acurácia 0,01 mg), distribuia-se os mesmos sobre placas cerâmicas esterilizadas (fig. 1.1 a 1.6 ) onde posteriormente ocorreria a espatulação..

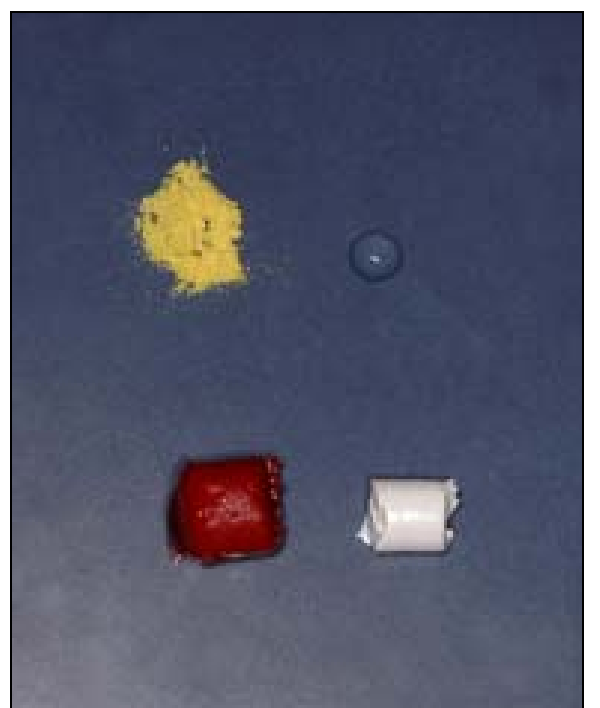

Fig. 1.1 - Grupo 1: Pasta zinco-enólica, iodofórmio e glicerina.

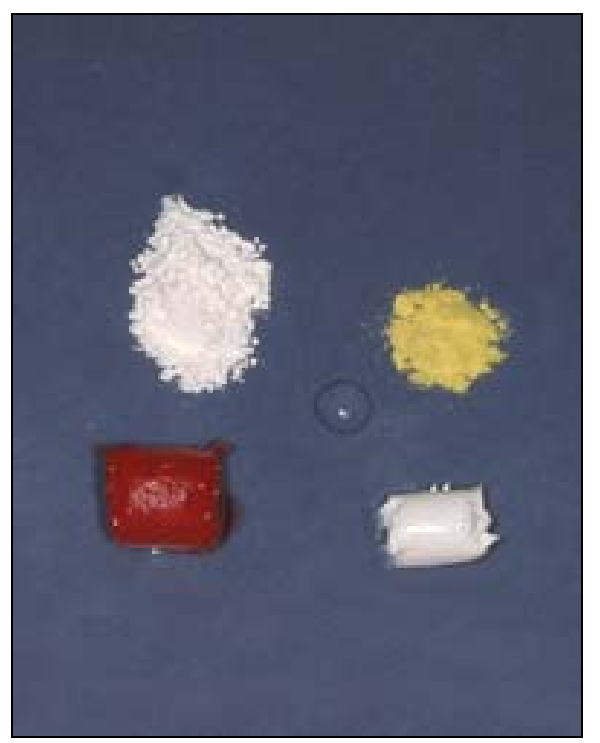

Fig. 1.3 - Grupo 3: Pasta zincoenólica, hidróxido de cálcio, iodofórmio e glicerina.

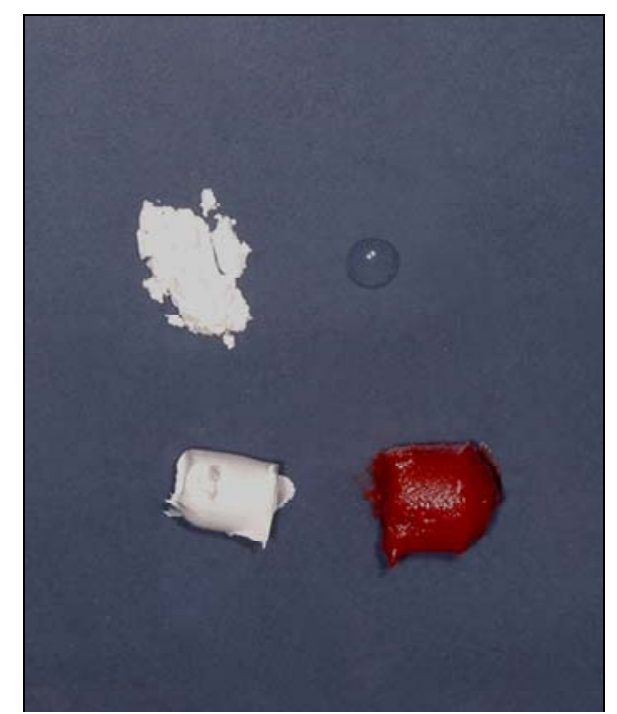

Fig. 1.2 - Grupo 2: Pasta zinco-enólica, subnitrato de bismuto e glicerina.

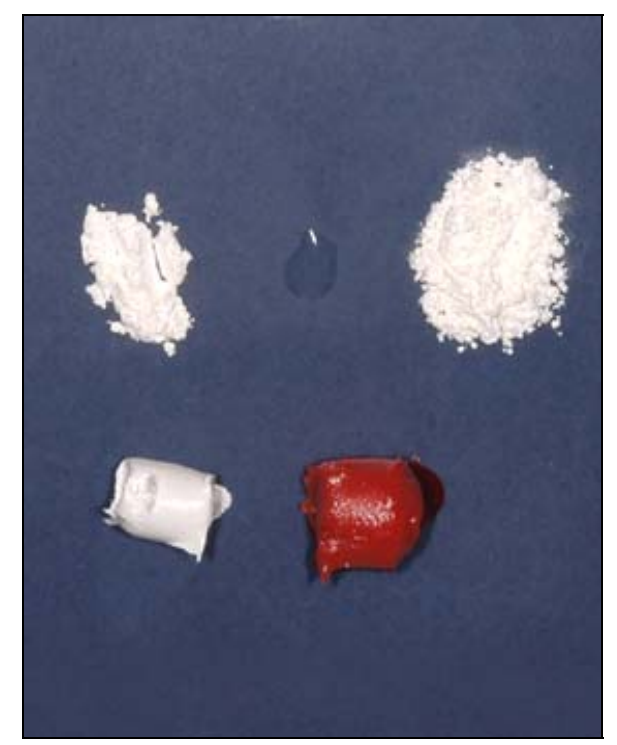

Fig. 1.4 - Grupo 4: Pasta zinco-enólica, hidróxido de cálcio, subnitrato de bismuto e glicerina. 
* MetTler toledo S/A - São Paulo SP.

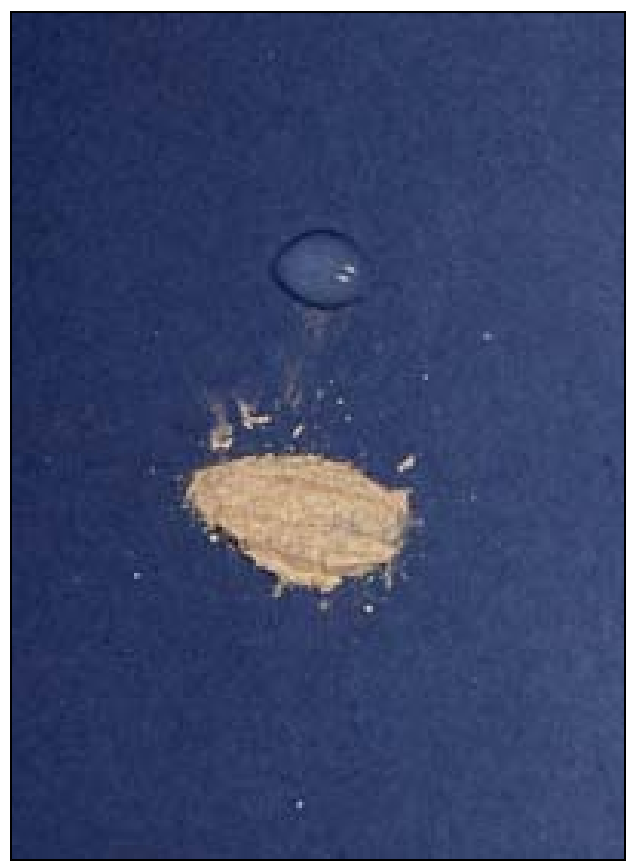

Fig. 1.5 - Grupo 5: Trióxido mineral agregado e água destilada.

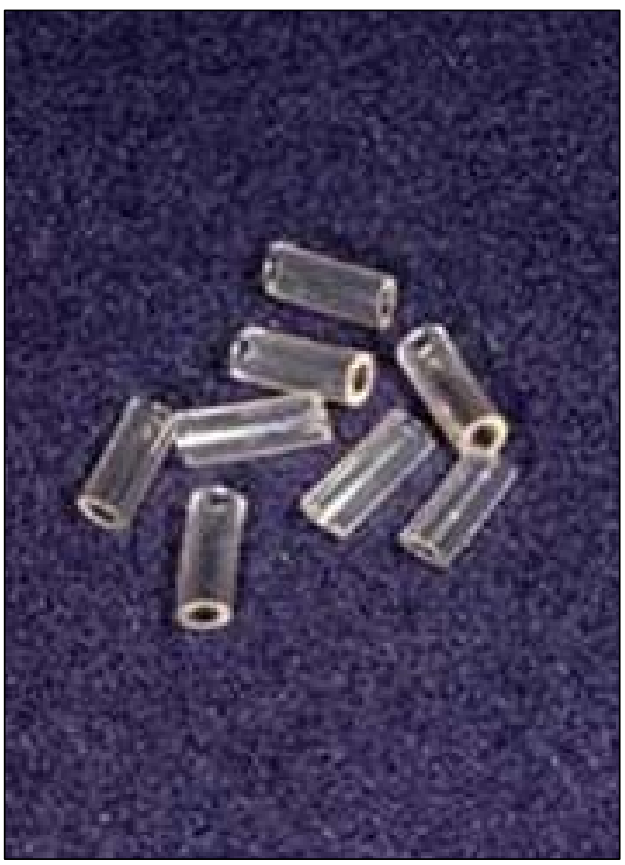

Fig. 1.6 - Grupo controle: Tubos de P.V.C siliconizado.

\subsection{Seleção e Distribuição dos Animais}

Para o experimento, dispusemos de cinquenta e um ratos machos, adultos, da linhagem Wistar (Rattus Norvergicus Albinus), com peso entre 400 e 4509, cedidos gentilmente pelo biotério da Faculdade de Odontologia de Bauru - USP. Até o momento das cirurgias, os animais permaneceram com ração e água ad lilbitum, divididos 10 gaiolas plásticas identificadas contendo 5 ratos cada, em sala arejada provida de temperatura controlada e luz tanto natural quanto artificial, 


\subsection{Preparo Pré-Operatório e Cirurgia de Implantação}

As drogas anestésicas injetadas no membro inferior esquerdo de cada animal foram quetamina* (Anasedan $®$ ) associada a xilazina* (Dopalen@), nas dosagens respetcivas de 0,01mg/g e $0,025 \mathrm{mg} / \mathrm{g}$. Constatados os efeitos do anestésico, procedeu-se ao corte, com lâmina de barbear, da pelagem da perna direita (Fig. 4.1). Este procedimento facilita a antissepsia da pele, realizada com gluconato de clorexedina a $2 \%$ ** (Chlorohex $($ ), bem como reduz a possibilidade da introdução acidental de pelos no tecido conjuntivo.

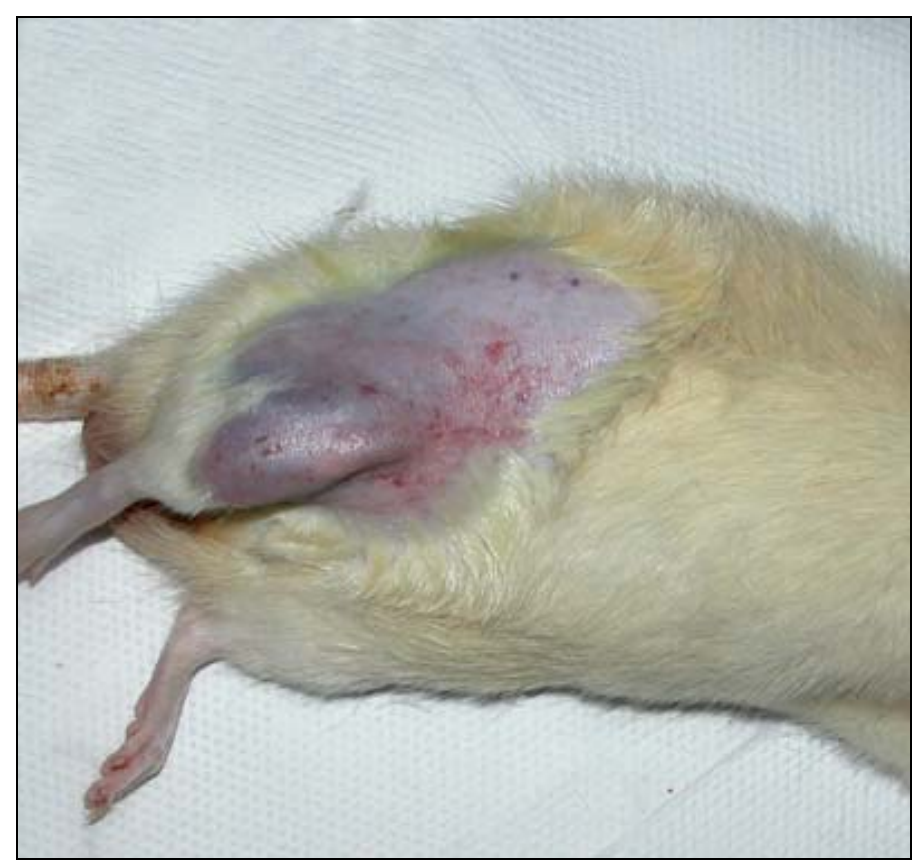

Fig. 2 - Tricotomia da pele do rato.

\footnotetext{
*Agribrands do Brasil Ltda. - Paulínia SP

** Qualiplus Ltda - Rio de Janeiro RJ
} 
Em seguida, realizou-se incisões lineares cutânea e muscular, com lâmina de bisturi $n^{0} 15$ montada, a fim de expor a região dorsal distal do fêmur e também a região dorsal proximal da tíbia e facilitar o descolamento do periósteo e acesso ao sítio cirúrgico (Figs. 3.1 e 3.2). Com auxílio de broca esférica número 6, girando em baixa rotação e sob irrigação constante com soro fisiológico (Fig. 4). criou-se um defeito ósseo em forma de canaleta de aproximadamente 8 mm de comprimento, em cada osso do mesmo animal /Figs. 5.1 e 5.21 .

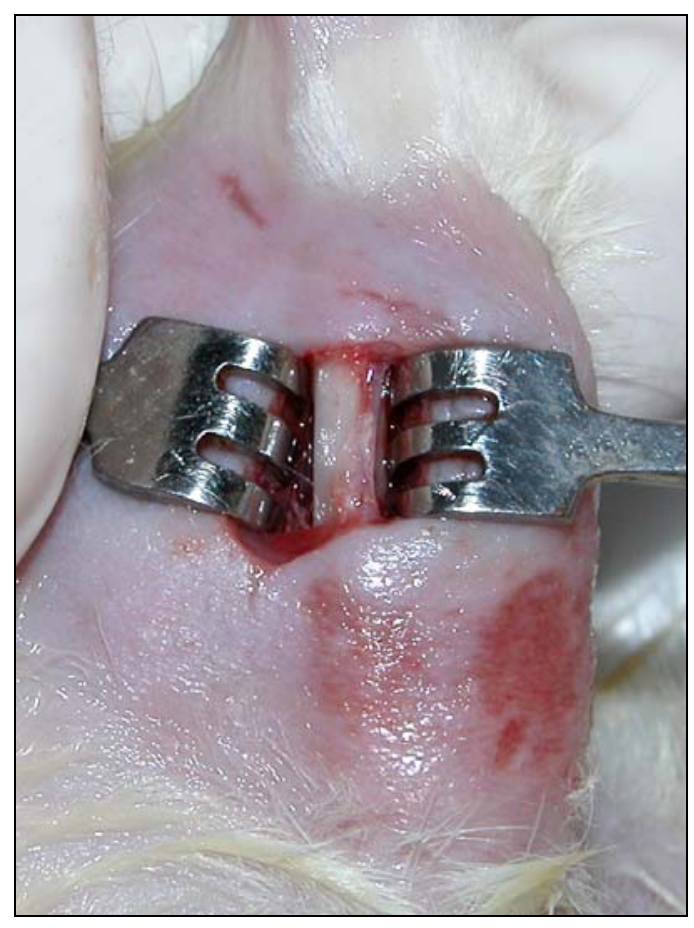

Fig. 3.1 - Exposição da tíbia direita do rato.

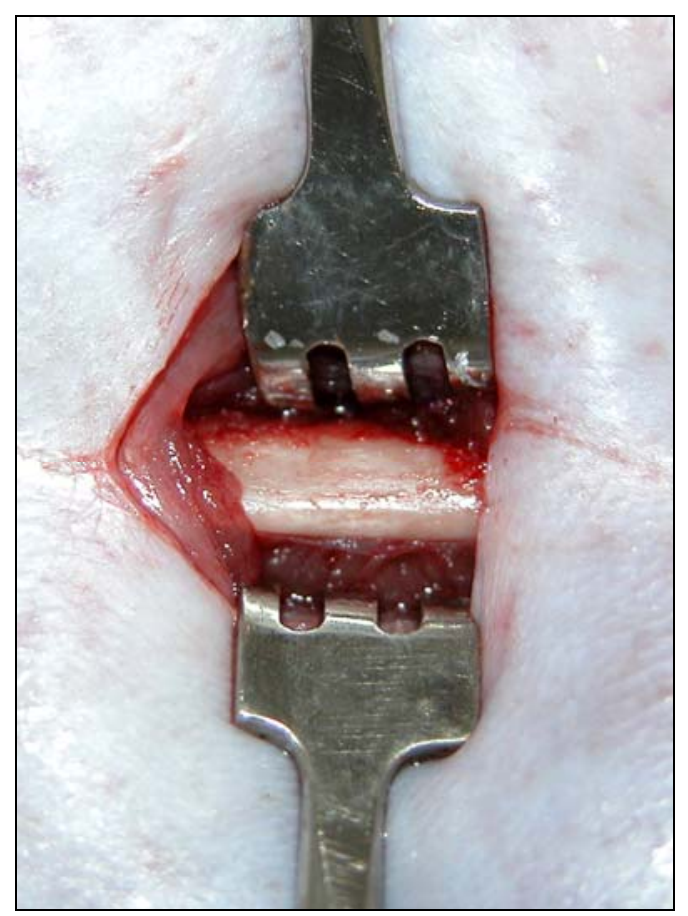

Fig. 3.2 - Exposição do fêmur direito do rato. 


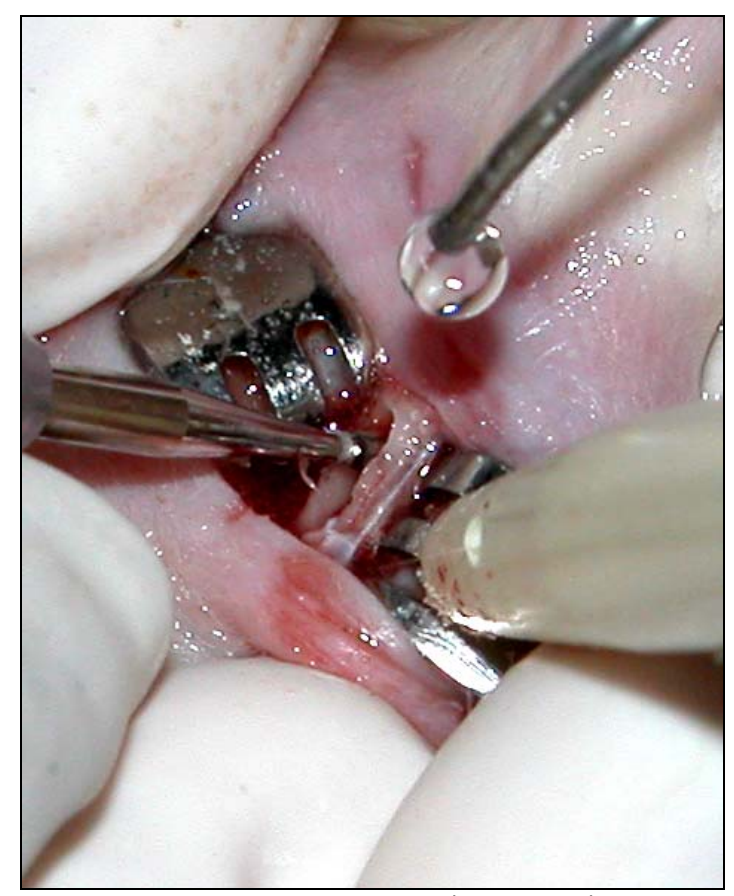

Fig. 4 - Preparo da loja óssea na tíbia.

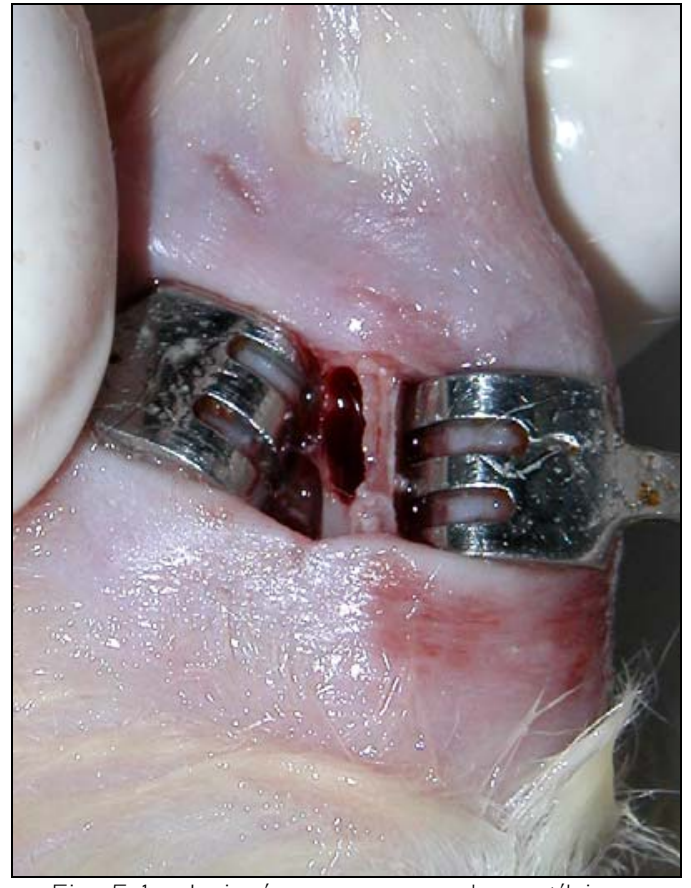

Fig. 5.1 - Loja óssea preparada na tíbia.

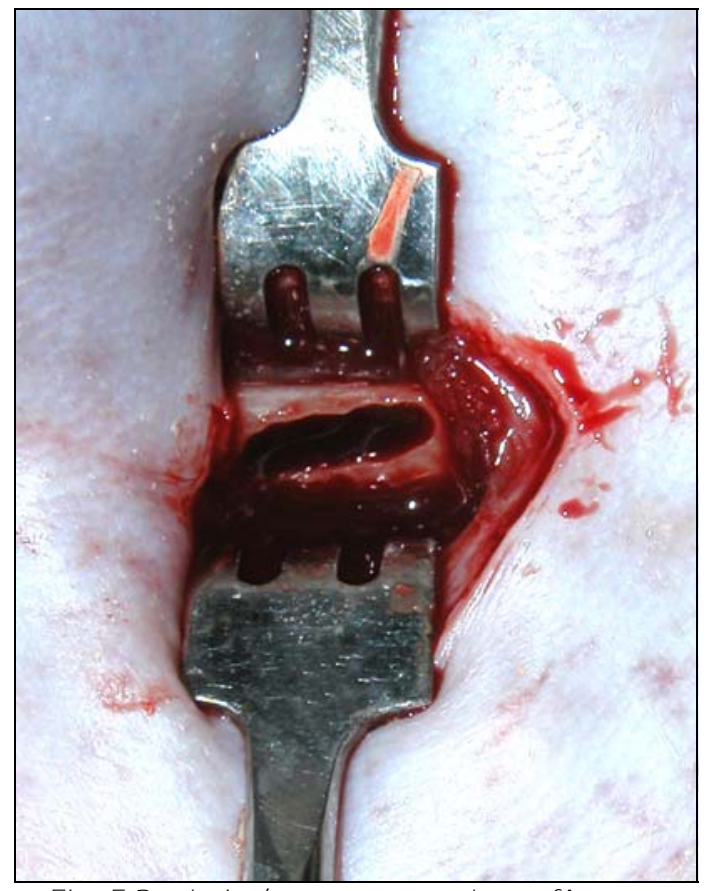

Fig. 5.2 - Loja óssea preparada no fêmur. 


\subsection{Preparo dos Implantes}

A manipulação dos materiais de cada um dos grupos seguiu as orientações dos fabricantes. Os cimentos á base de pasta zinco-enólica foram espatulados, por aproximadamente 30 segundos, até que se obtivesse uma pasta de cor homogênea e consistente (Fig.6.1), enquanto o cimento reparador MTA® foi homogeneizado junto à água destilada, produzindo uma substância arenosa (Fig.6.2).

Os dispositivos a serem preenchidos e empregados como limitadores do contato das substâncias com os tecido foram cilindros confeccionados a partir de cortes transversais, a cada $5 \mathrm{~mm}$ do longo eixo, de sonda uretral estéril $n^{\circ}$ 4* (Figs. 7.1, 7.2 e 7.3).

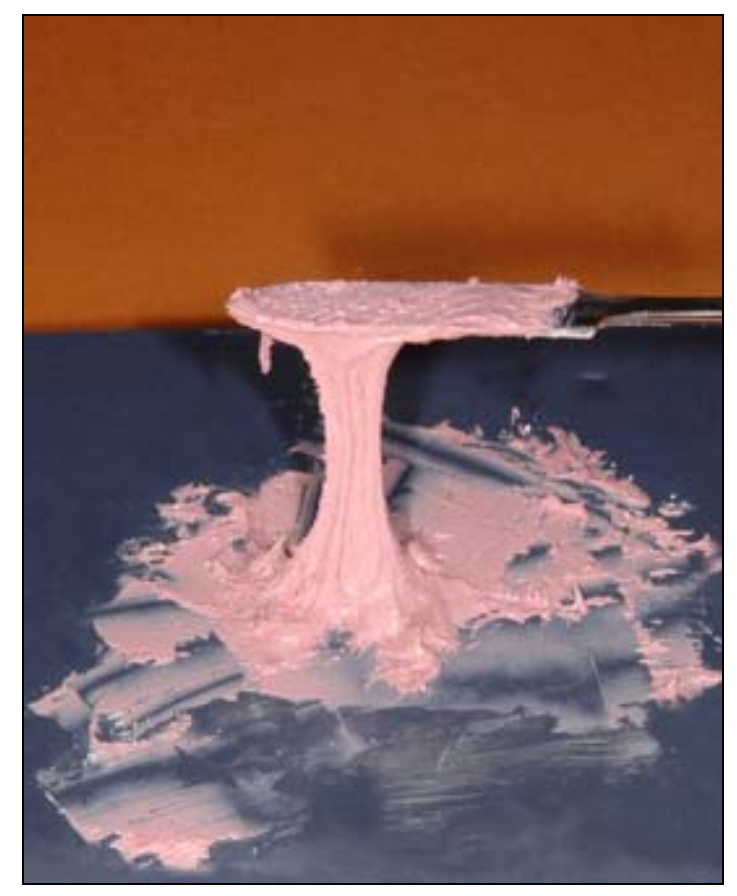

Fig. 6.1 - Espatulação dos cimentos à base de pasta zinco-enólica.

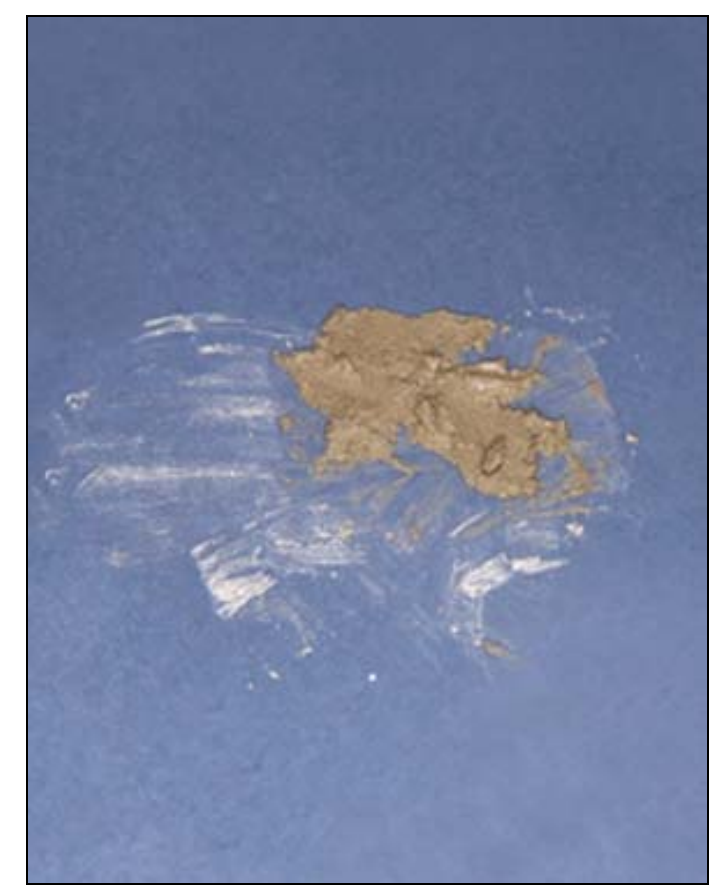

Fig. 6.2 - Trióxido mineral agregado espatulado.

\footnotetext{
* Fabrimed - Santo Antonio de Posse SP.
} 
Com os materiais em fase plástica, os mesmos foram inseridos dentro dos cilíndros de P.V.C. até o término do preenchimento. Cuidou-se para que o cimento permanecesse ao nível da embocadura do tubo em ambas extremidades. (figs. 7.1 e 7.2).

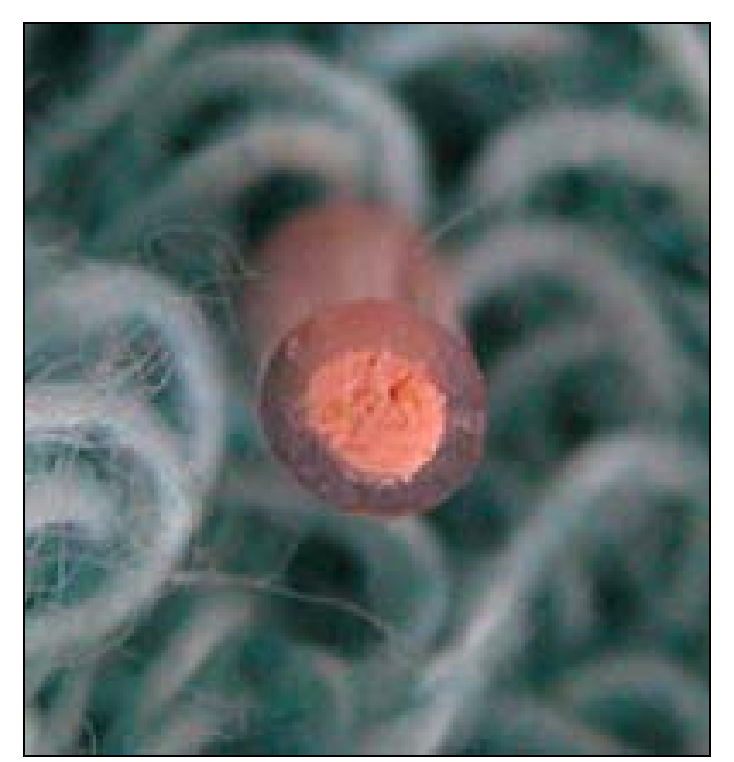

Fig. 7.1 - Limite representativo de preenchimento dos tubos providos de pasta zinco-enólica e aditivos.

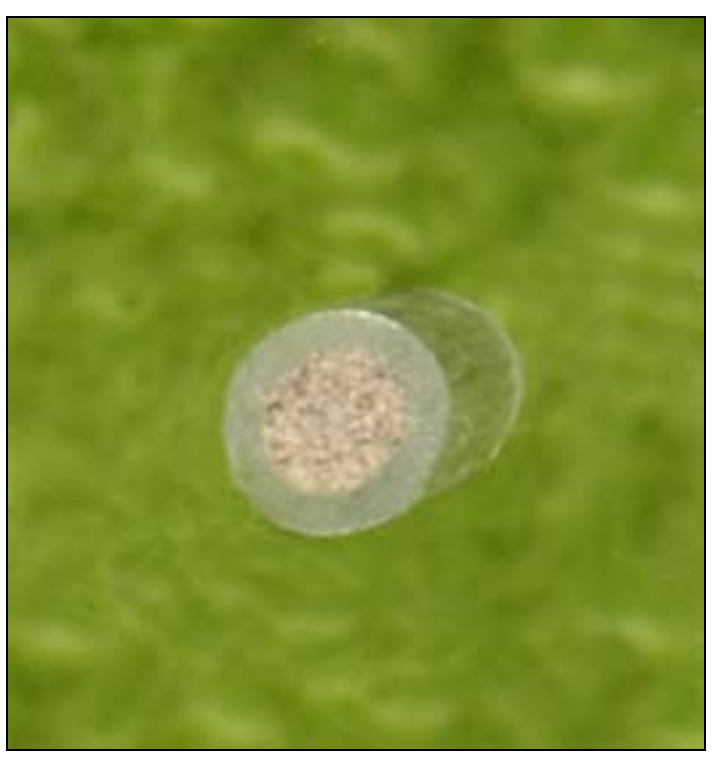

Fig. 7.2 - Limite de preenchimento dos tubos dotados de agregado de trióxido mineral.

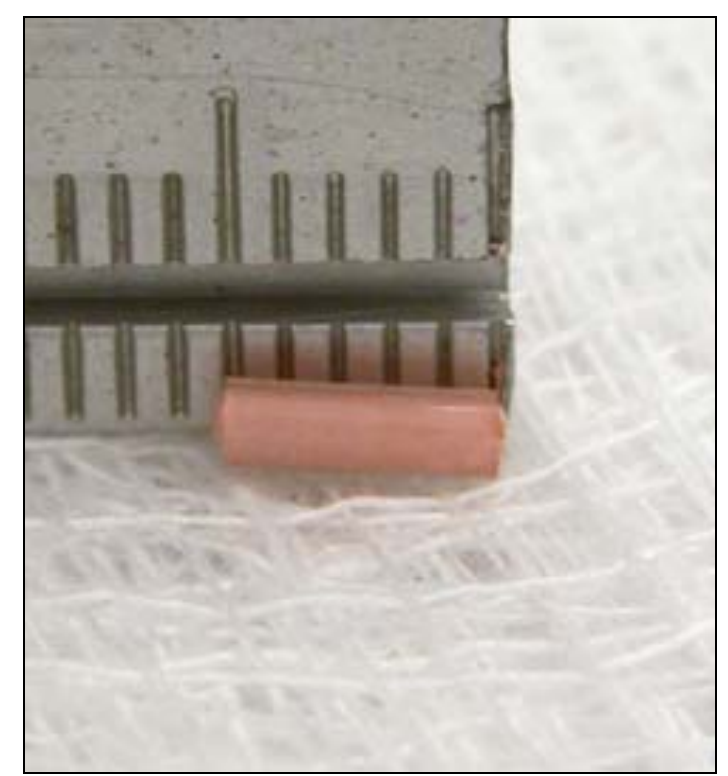

Fig. 7.3 - Vista lateral do tubo denotando seu comprimento e o preenchimento completo pelos materiais. 
Definiu-se aleatoriamente quais os materiais seriam inseridos na tibia e fêmur de cada cobaia, priorizando a diferença dos compostos em um mesmo animal, a fim de reduzir possiveis interferências decorrentes de diferentes resposta do organismo aos procedimentos cirúrgicos e materiais. O grupo controle foi constituído de tubos vazios semelhantes aos preenchidos pelos materias e abertos em ambas extremidades.

Marcações realizadas no pavilhão auditivo dos ratos, ̀̀ medida que as implantações eram executadas, identificavam os materiais que cada animal portava.

Ao fim desta etapa, obteve-se 6 grupos diferentes de compostos para cada período experimental de 30, 60 e 90 dias pósimplantações.

Tabela 13 - Número de amostras de cada material em função dos diferentes períodos experimentais.

$\begin{array}{ccccc}\text { GRUPOS } & 30 \text { DIAS } & \text { 60 DIAS } & 90 \text { DIAS } & \text { TOTAL DE AMOSTRAS } \\ \text { Grupo 1 } & 6 & 6 & 6 & 18 \\ \text { Grupo 2 } & 6 & 6 & 6 & 18 \\ \text { Grupo 3 } & 6 & 6 & 6 & 18 \\ \text { Grupo 4 } & 6 & 6 & 6 & 18 \\ \text { Grupo 5 } & 6 & 6 & 6 & 18 \\ \text { Grupo Controle } & 4 & 4 & 4 & 12\end{array}$




\subsection{Implantação dos Tubos Preenchidos e Período Pós-Operatório Inicial}

Os tubos de polietilenos foram então introduzidos em seus respectivos defeitos ósseos (Figs. 8.1 e 8.2), verificando-se a estabilidade dos mesmos na loja óssea antes de proceder às suturas.

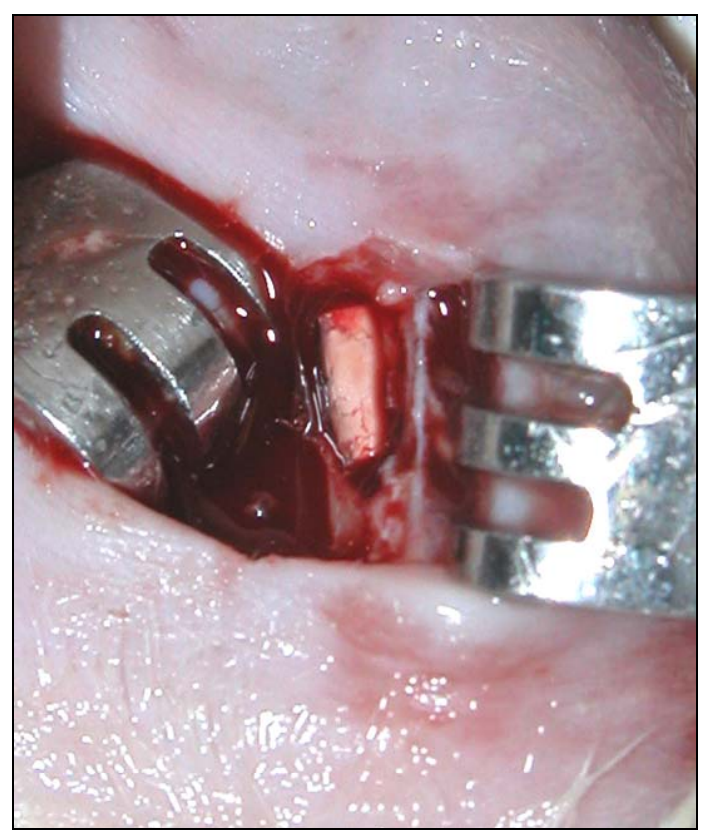

Fig. 8.1 - Implantação do tubo preenchido na tíbia (Pasta LS® e subnitrato de bismuto).

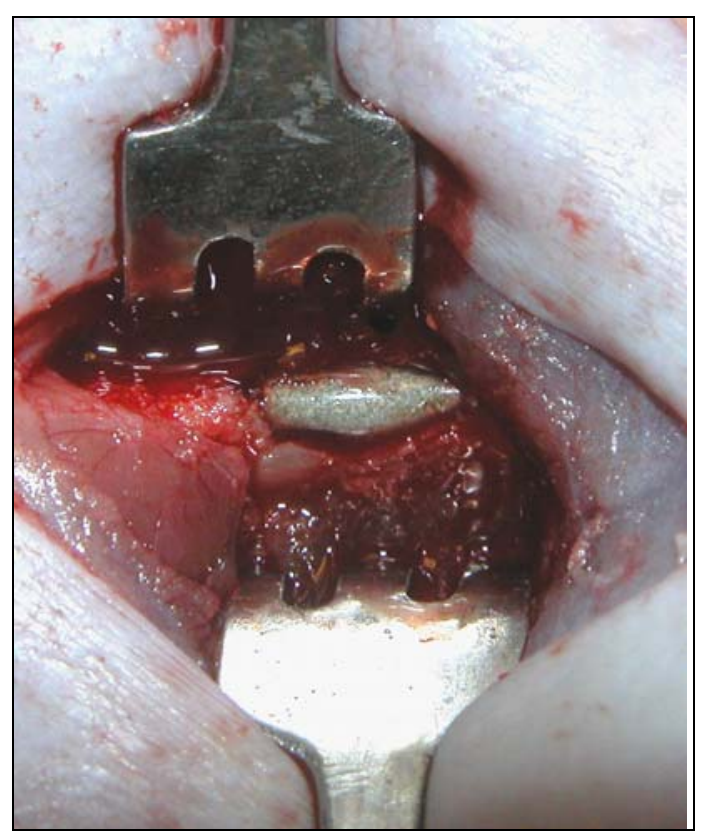

Fig. 8.2 - Implantação do tubo preenchido no fêmur (Trióxiido Mineral Agregado).

Após justaposição dos tecidos musculares, realizou-se sutura intramuscular contínua (Fig. 9.1) com fio tipo Cat Gut* cromado multifilamentado reabsorvível 5.0 e em seguida a sutura interrompida da derme com fio de seda preta trançada não reabsorvível 4.0** (Fig. 9.2).

\footnotetext{
*Paramed Suturas - São Paulo SP

* * Shalon - São Paulo SP
} 


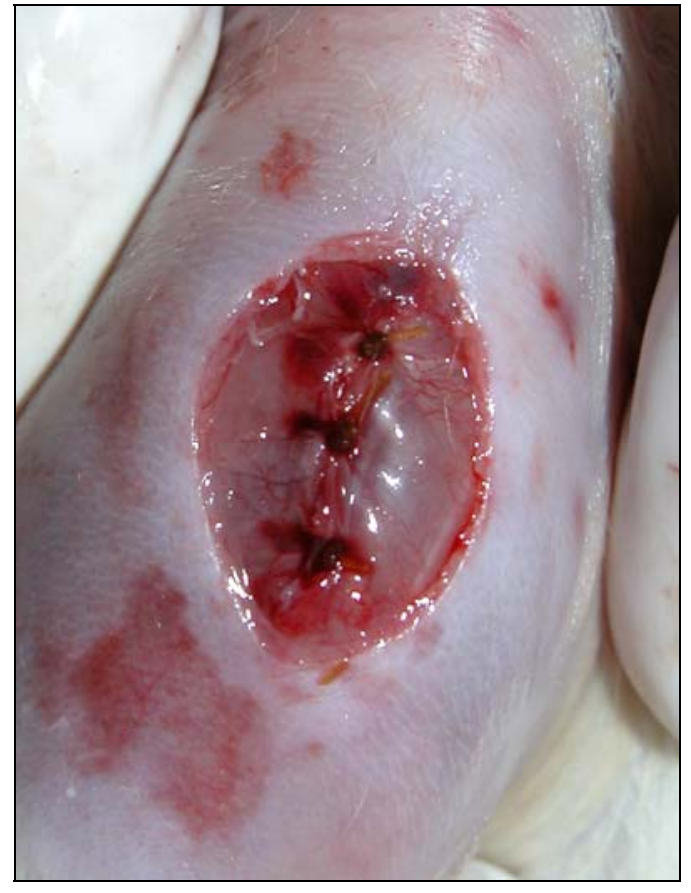

Fig. 9.1 - Aspecto da sutura muscular

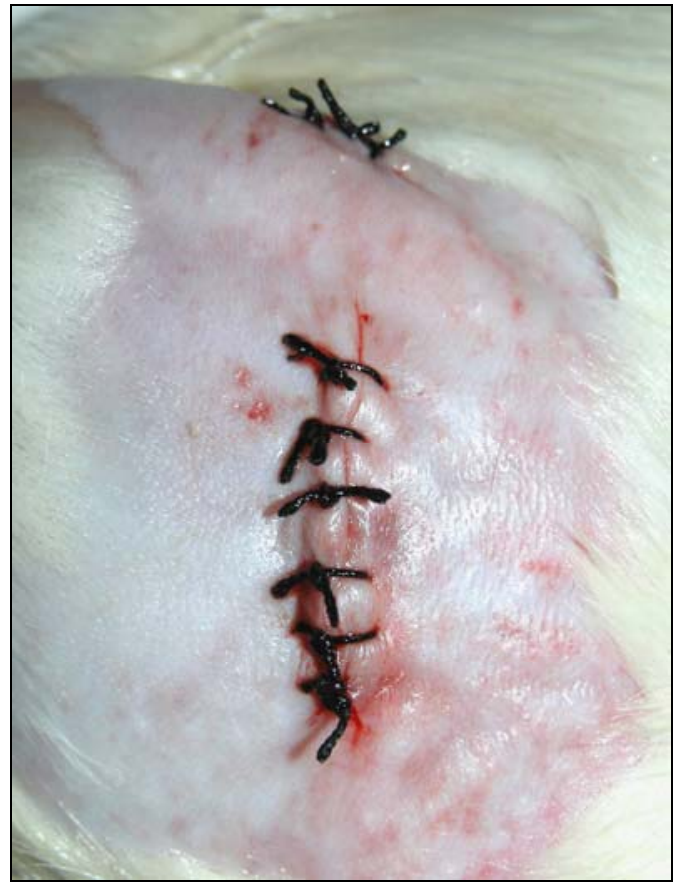

Fig.9.2 - Aspecto da sutura da pele.

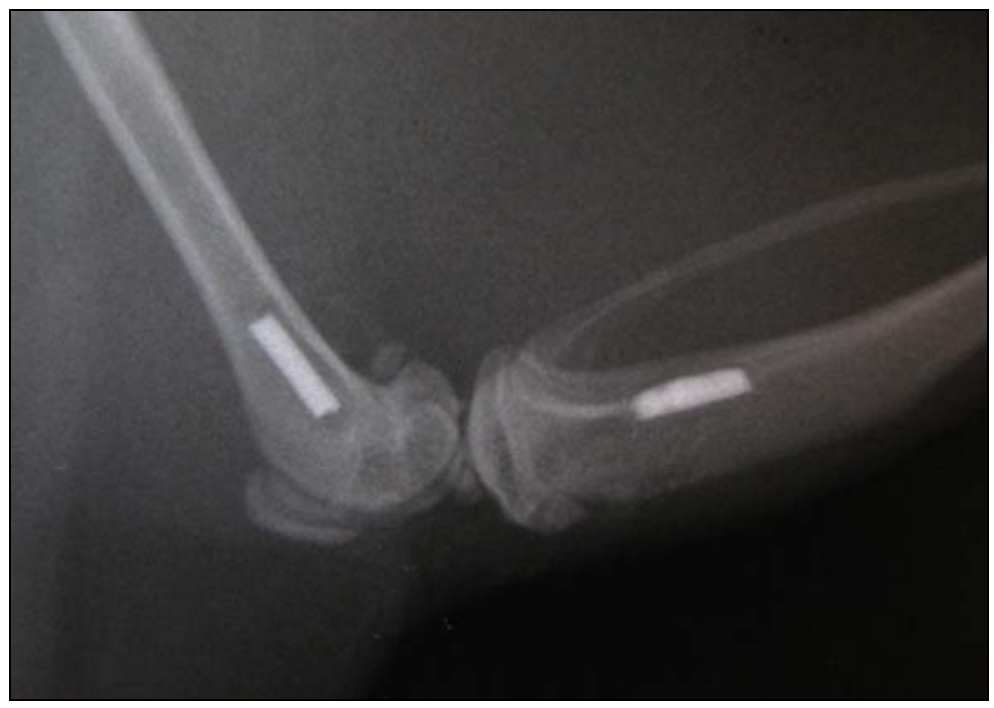

Fig. 10 - Radiografia pós-operatória mostrando a localização dos tubos no interior do osso (notar a radiopade dos materiais). 
No período pós-cirúrgico imediato, administrou-se em todos os animais um antinflamatório (Ketofen@* 1\% injetável 0,02m//g) por 3 dias e um antimicrobiano (Flotril ** 2,5\% injetável 0,005ml/g) por 5 dias, até que os fenômenos dolorosos diminuíssem de intensidade. Removeu-se o fio de sutura da derme dos animais no sétimo dia após os procedimentos cirúrgicos.

No período de aguardo da coletas das peças, os animais foram observados semanalmente quanto à mudanças de comportamento.

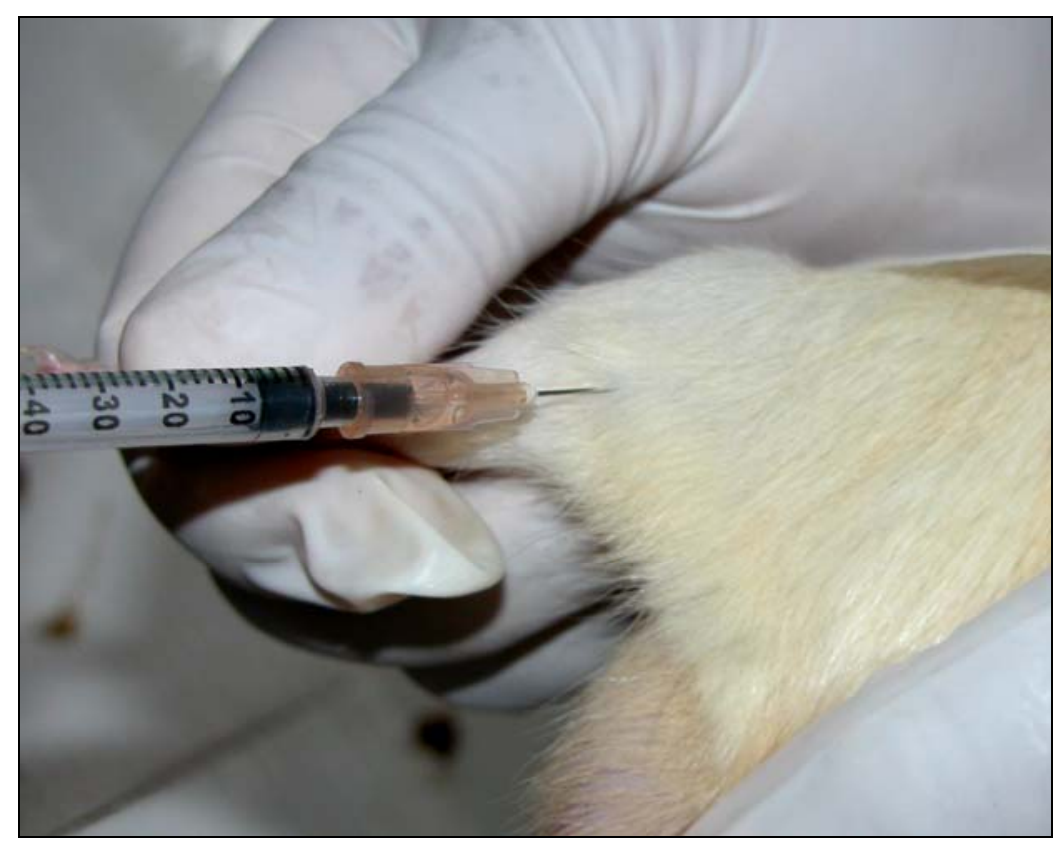

Fig. 11 - Aplicação da medicação pós-operatória.

* Merial Saúde Animal Ltda - Paulínia SP

** Schering-Plough S/A - Rio de Janeiro RJ 


\subsection{Coleta das Peças e Processamento para Análise Microscópica}

Em cada um dos períodos experimentais de 30, 60 e 90 dias pós-cirurgicos, coletou-se as pernas direitas de 17 animais após os mesmos serem mortos por dosagem excessiva de anestésico. A escolha dos animais foi aleatória para cada período, de modo que um dos três ratos portadores dos mesmos materiais tivesse 33,3, 50 e 100\% de chances respectivamente de ser escolhido como amostra a ser coletada. Desarticulou-se o membro inferior direito inteiro para facilitar a remoção dos tecidos muscular e epitelial (Figs. 11.1 e 11.2). Em seguida, as peças eram imediatamente imersas em solução de formol tamponado a 10\%, onde permaneceram por 7 dias.

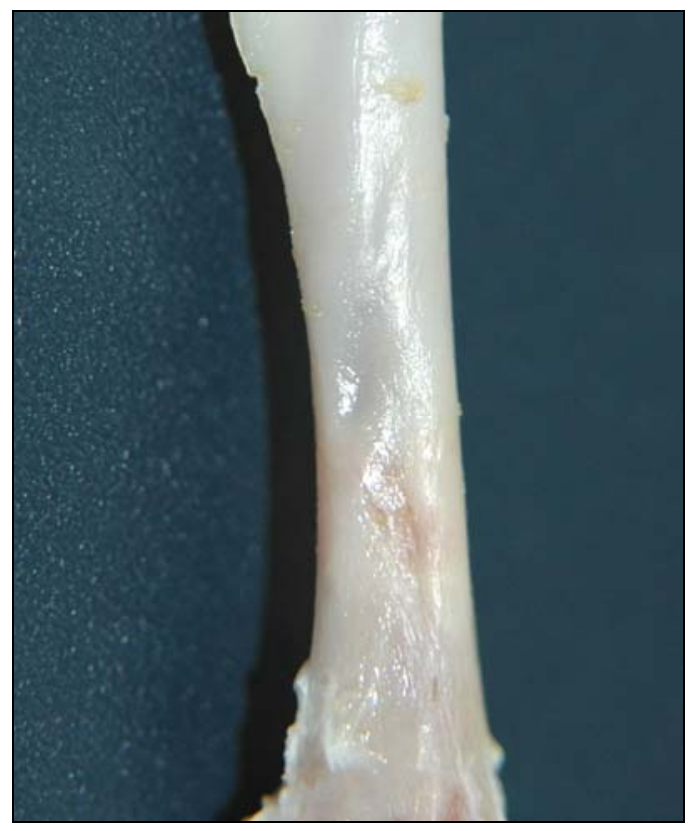

Fig. 11.1 - Aspecto do osso fêmural preparado para desmineralização.

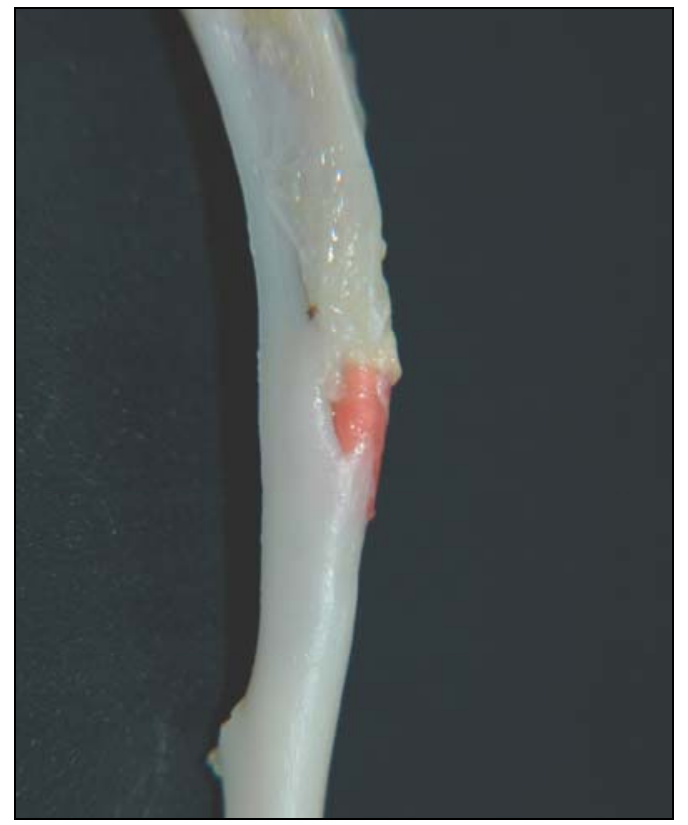

Fig. 11.2 - Tíbia após remoção dos tecidos musculares e pronta para desmineralização (notar o recobrimento ósseo do tubo). 
A desmineralização aconteceu em ácido diaminotetracético (EDTA) a 2\% com trocas semanais. Ao notar-se flexibilidade inicial dos espécimes, as peças eram reduzidas e os tubos cuidadosamente removidos a fim de acelerar o processo de descalcificação. A confirmação do término desta etapa foi verificada por análise radiográfica do conteúdo mineral dos espécimes.

As peças sofreram banhos sucessivos de álcool e xilol concentrados antes de serem incluídas em parafina. A solidificação dos blocos facilitou a obtenção de cortes semi-seriados de $5 \mu \mathrm{m}$ de espessura, em micrótomo, para a confecção das lâminas. processamento histotécnico completo, finalizado pela coloração das lâminas em hematoxilina e eosina (HE) ocorreu nas dependencias do departamento de Histologia da Faculdade de Odontolgia de Bauru.

\subsection{Análise Microscópica}

O exame das reações do tecido ósseo medular frente aos implantes foi executado por observador único proficiente, auxíliado por microscópio binocular Aristoplan*, sem que o patologista tivesse conhecimento do material experimental empregado. Simultâneo à descrição dos aspectos microscópicos abrangentes de cada lâmina, avaliou-se separadamente os fenômenos inflamatórios e osteogênicos, com base em critérios pré-estabelecidos, de modo a quantificá-los, conforme escores representativos (tabelas 14 a 19), para a comparação através de testes estatísticos.

* Leitz Wetzlar - Germany 
Tabela 14 - Critérios de avaliação microscópica e respectivos valores ordinais relativos ao infiltrado inflamatório crônico.

$\begin{array}{ccl}\text { Denominação } & \text { Escores } & \text { Aspecto Microscópico } \\ \text { Ausente } & 0 & \text { sem células inflamatórias } \\ \text { Leve } & 1 & \begin{array}{l}\text { macrófagos e linfócitos esparso } \\ \text { macrófagos, linfócitos e células plasmática } \\ \text { Moderado }\end{array} \\ \text { Severo } & 3 & \begin{array}{l}\text { acúmulo considerável de macrófagos e } \\ \text { polimorfonucleares }\end{array}\end{array}$

Tabela 15 - Critérios de avaliação microscópica e respectivos valores ordinais referentes à presença de necrose tecidual.

$\begin{array}{ccl}\text { Denominação } & \text { Escores } & \text { Aspecto Microscópico } \\ \text { Ausente } & 0 & \begin{array}{l}\text { sem vestígios de sombras arquiteturais ou } \\ \text { fragmentos de núcleos celulares }\end{array} \\ \text { Presente } & 1 & \begin{array}{l}\text { presença de sombras arquiteturais ou } \\ \text { fragmentos de núcleos celulares }\end{array}\end{array}$

Tabela 16 - Critérios de avaliação microscópica e respectivos valores ordinais quanto á presença de células gigantes multinucleadas.

$\begin{array}{ccl}\text { Denominação } & \text { Escores } & \text { Aspecto Microscópico } \\ \text { Ausente } & 0 & \begin{array}{l}\text { macrófagos isoladas ou reunidos com } \\ \text { separação visível dos seus citoplasmas } \\ \text { Presente }\end{array} \\ 1 & \begin{array}{l}\text { fusão de } 8 \text { ou mais macrófagos dentro } \\ \text { de um mesmo citoplasma }\end{array}\end{array}$

Tabela 17 - Critérios de avaliação microscópica e respectivos valores ordinais referentes ao aspecto do tecido de granulação.

\begin{tabular}{|c|c|c|}
\hline Denominação & Escores & Aspecto Microscópico \\
\hline Denso e modelado & 0 & $\begin{array}{l}\text { fibras colágenas justapostas } \\
\text { oraanizadas no mesmo sentido }\end{array}$ \\
\hline Denso não-modelado & 1 & $\begin{array}{l}\text { fibras colágenas justapostas, porem em } \\
\text { sentidos diversos }\end{array}$ \\
\hline Frouxo & 2 & $\begin{array}{l}\text { fibras colágenas separadas e dispostas } \\
\text { em sentidos diversos }\end{array}$ \\
\hline
\end{tabular}


Tabela 18 - Critérios de avaliação microscópica e respectivos valores ordinais quanto á quantidade de trabéculas ósseas na interface com os materiais.

\begin{tabular}{|c|c|c|}
\hline Denominação & Escores & Aspecto Microscópico \\
\hline Grandes & 0 & $\begin{array}{l}\text { trabéculas na interface com o material } \\
\text { equivalentes, em tamanho a 1/7 avos do } \\
\text { diâmetro do tubo ou maiores }\end{array}$ \\
\hline Médias & 1 & $\begin{array}{l}\text { trabéculas na interface com o material } \\
\text { equivalentes, em tamanho a } 1 / 12 \text { avos } \\
\text { do diâmetro do tubo }\end{array}$ \\
\hline Pequenas & 2 & $\begin{array}{l}\text { trabéculas na interface com o material } \\
\text { equivalentes, em tamanho a } 1 / 20 \text { avos } \\
\text { do diâmetro do tubo }\end{array}$ \\
\hline Ausentes & 3 & $\begin{array}{l}\text { nenhuma trabécula visível na interface } \\
\text { com o material }\end{array}$ \\
\hline
\end{tabular}

Tabela 19 - Critérios de avaliação microscópica e respectivos valores ordinais referentes ao grau de formação de barreira óssea entre o tecido de granulação e o medular.

\begin{tabular}{|c|c|c|}
\hline Denominação & Escores & Aspecto Microscópico \\
\hline Completa & 0 & $\begin{array}{l}\text { trabéculas ósseas à distância e } \\
\text { recobrindo completamente } \\
\text { extremidade do tubo }\end{array}$ \\
\hline Semicompleta & 1 & $\begin{array}{l}\text { trabéculas ósseas à distância e } \\
\text { recobrindo entre } 50 \text { a } 70 \% \text { do diâmetro } \\
\text { do tubo }\end{array}$ \\
\hline Parcial & 2 & $\begin{array}{l}\text { trabéculas ósseas à distância e } \\
\text { recobrindo menos de 50\% do diâmetro } \\
\text { do tubo }\end{array}$ \\
\hline $\begin{array}{l}\text { Presente nas } \\
\text { extremidades }\end{array}$ & 3 & $\begin{array}{l}\text { projeções osteóides restritas e adjacentes } \\
\text { ao endósteo }\end{array}$ \\
\hline Ausente & 4 & $\begin{array}{l}\text { nenhuma formação óssea presente à } \\
\text { distância do material }\end{array}$ \\
\hline
\end{tabular}


Tivemos que abandonar a tranqüila quietude de já ter decifrado o mundo.

Ilya Prigogine

\section{$\underline{\text { RESULTADOS }}$}




\section{RESULTADOS}

5.1 Avaliação Descritiva Subjetiva dos Achados Microscópicos Relativos ao Período de Trinta Dias

Controle: A extremidade do implante revela tecido de granulação, invaginando-se para a luz do tubo, acompanhado de trabéculas ósseas neoformadas que não permitem, ainda, isolamento total do tecido medular. O tecido de granulação invaginado assume aspecto de maturação, com discreto infiltrado inflamatório crônico e trabéculas ósseas em ativo processo de desenvolvimento (Fig. 12.1).

Trióxido mineral agregado: A região analisada exibe predominância de tecido ósseo em contato direto com o material implantado, separando totalmente o tecido medular (Fig. 13.1). De permeio às trabéculas do tecido ósseo neoformado, o tecido de granulação apresenta-se em processo de maturação, com discreto infiltrado inflamatório crônico (Fig. 13.2).

Pasta zinco-enólica acrescida de subnitrato de bismuto: Observase a presença de tecido de granulação de aspecto denso e proliferação de fibroblastos, caracterizando a fase de maturação, envolvendo focos remanescentes de tecido necrótico e resquícios do material implantado. O infiltrado inflamatório crônico é discreto, com predomínio de macrófagos (Fig. 14.2). Nota-se invaginação do tecido e trabéculas osteóides em contato com o tubo, mas ausentes no contato com o cimento (Fig. 14.1). Ainda, células gigantes multinucleadas do tipo Langhans circundando partículas de material podem ser observadas (Fig. 16.2). 
Pasta zinco-enólica acrescida de subnitrato de bismuto e hidróxido de cálcio: A extremidade do tubo revela camada de tecido de granulação bem definida, com restos de tecido necrótico na sua superfície voltgada para a pasta e no outro lado mostra-se em contato direto com o tecido medular (Fig. 15.1). Este tecido de granulação exibe intenso infiltrado inflamatório crônico, predominantemente macrofágico (Fig. 15.2), com áreas demonstrando células gigantes multinucleadas (Fig. 16.1).

Pasta zinco-enólica acrescida de iodofórmio: $\bigcirc$ tecido de granulação localizado na extremidade do implante é espesso e está em contato direto com o tecido medular, apresentando no seu interior focos de tecido necrótico (Fig. 17.1). Esse tecido de granulação apresenta intensa reação inflamatória crônica em sua superfície de contato com o tecido medular, característica de processo de maturação, representado por um aumento de fibras colágenas e diminuição da população celular (Fig. 17.2).

Pasta zinco-enólica acrescida de iodofórmio e hidróxido de cálcio: A extremidade do implante demonstra uma camada de tecido de granulação bem definido e em contato direto com o tecido medular, havendo interposição, em algum ponto, de trabéculas de tecido ósseo neoformado (Fig. 18.1). $\bigcirc$ tecido de granulação exibe alguma característica de maturação e infiltrado inflamatório crônico moderado (Fig. 18.2). 


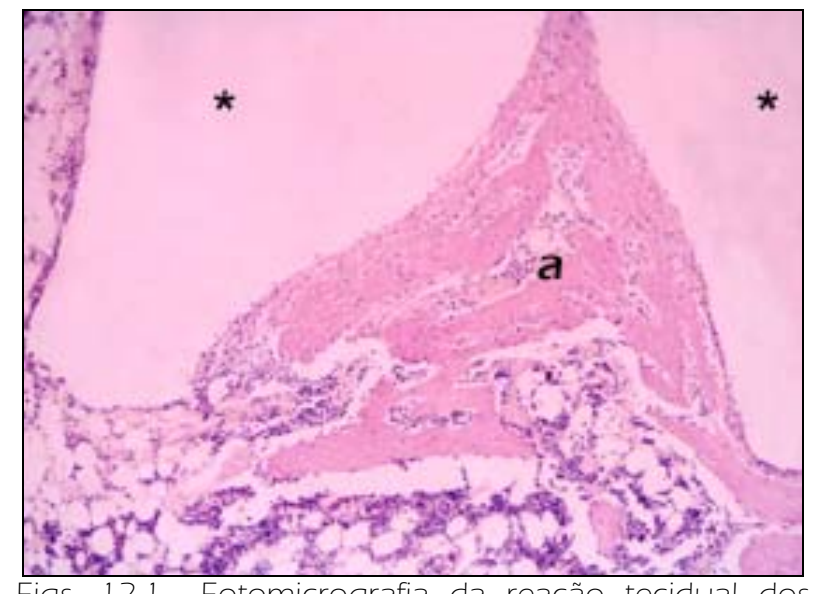

Figs. 12.1- Fotomicrografia da reação tecidual dos tubos vazios, aos 30 dias. Notar a invaginação do
tecido (a) limitado pelas paredes do tubo $(*)$ tecido (a) limitado pelas paredes do tubo * - aumento 4X.

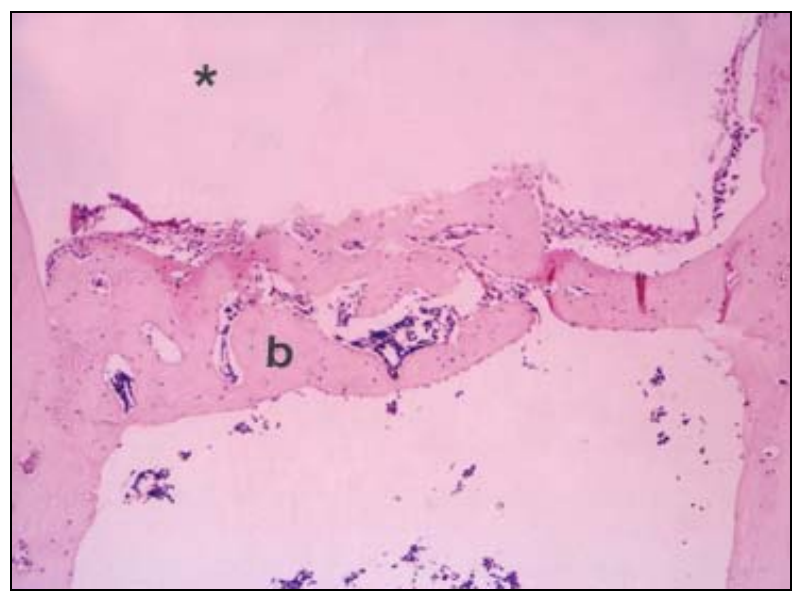

Fig. 13.1 - Fotomicrografia da reação tecidual ao triöxido mineral agregado aos 30 dias. Notar a presenca de barreira osteóide (b) separando o espaço referenet ao tubo $\left({ }^{*}\right)$ do tecido medular auménto 4X.

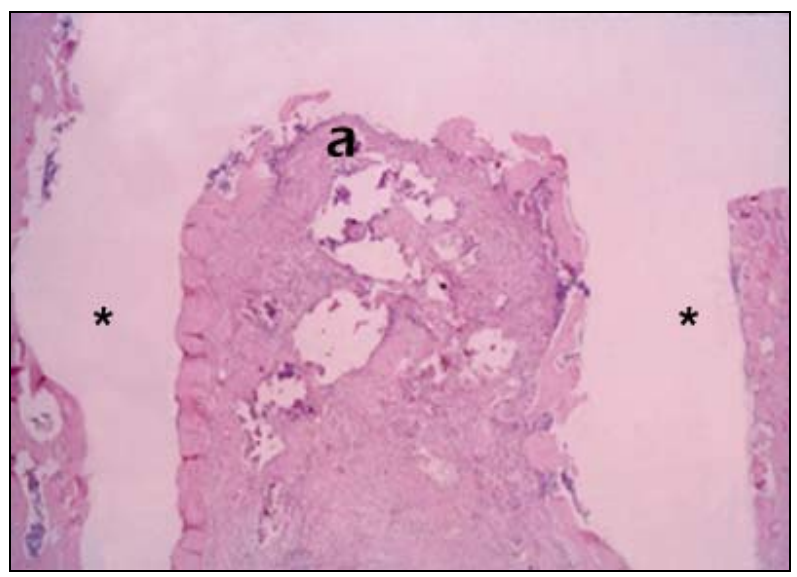

Fig. 14.1 - Fotomicrografia da reação tecidual à pasta zinco-enólica acrescida de subnitrato de bismuto, aos 30 dias. Notar a ausência de trabéculas ósseas no contato do tecido invaginado com o material (a), (* paredes do tubo) - aumento $4 X$.

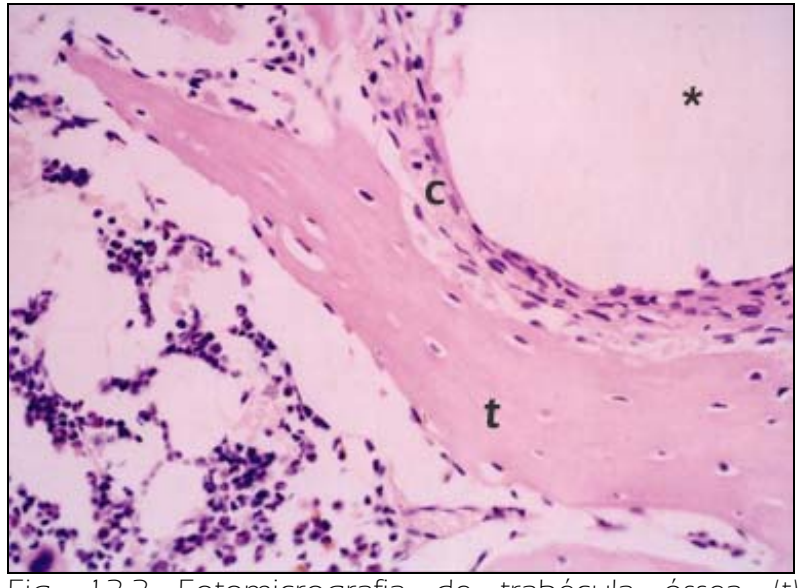

limitada do contato com a parede do tubo * * por delgada camada de tecido fibroso (c) - 30 dias aumento 10X

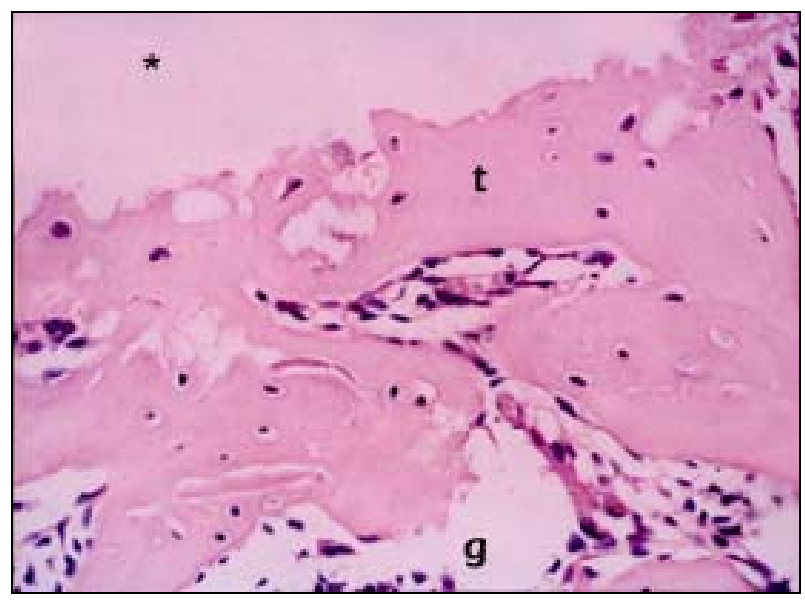

Fig. 13.2 - Fotomicrografias evidenciando o contato da trabécula óssea (t) com o material em teste (*). 9

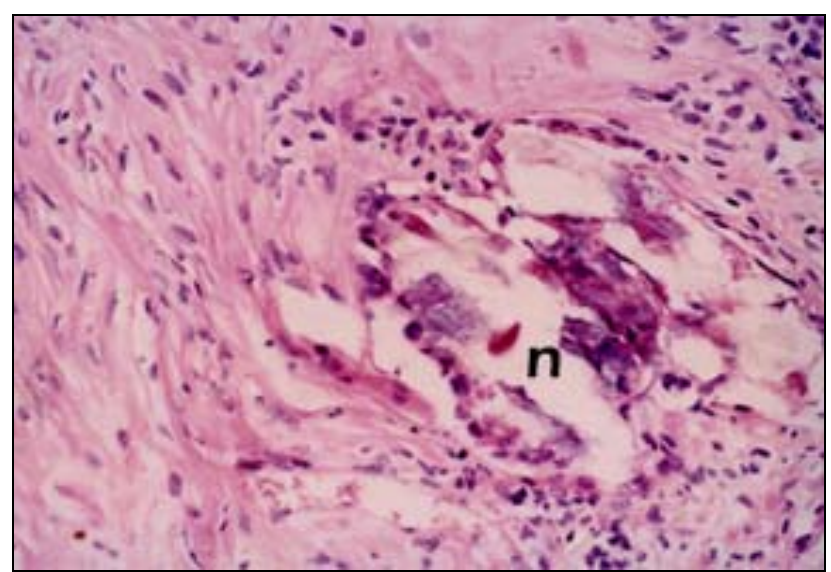

Fig 14.2 - Fotomicrografia do tecido de granulação. Notar o infiltrado inflamatório circundando a área de necrose tecidual (n) - aumento40X. 


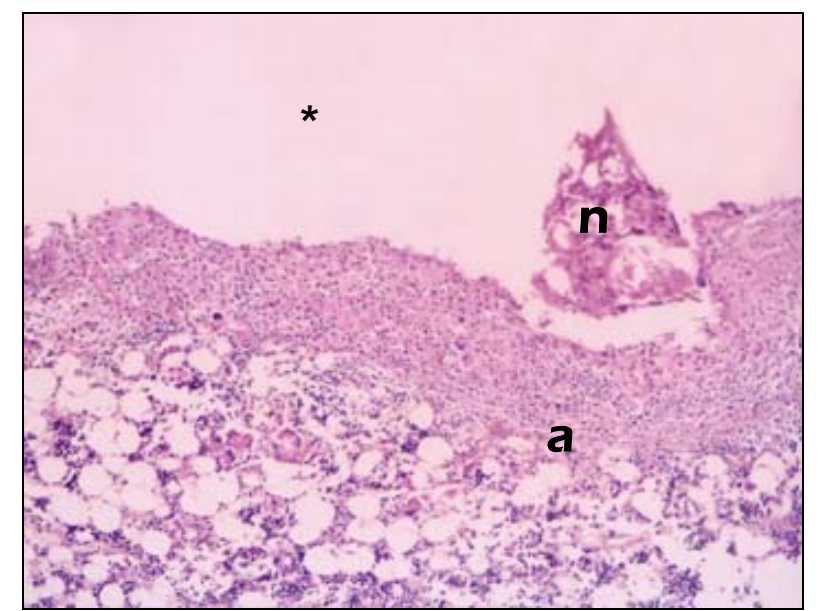

Fig. 15.1 - Fotomicrografia da reação tecidual à pasta zinco-enólica acrescida de subnitrato de bismuto e hidróxido de cálcio, aos 30 dias. Notar a presença de necrose (n) na interface com o espaço referente ao tubo $(*)$ e o contato do tecido de granulação com o medular - aumento 10X.

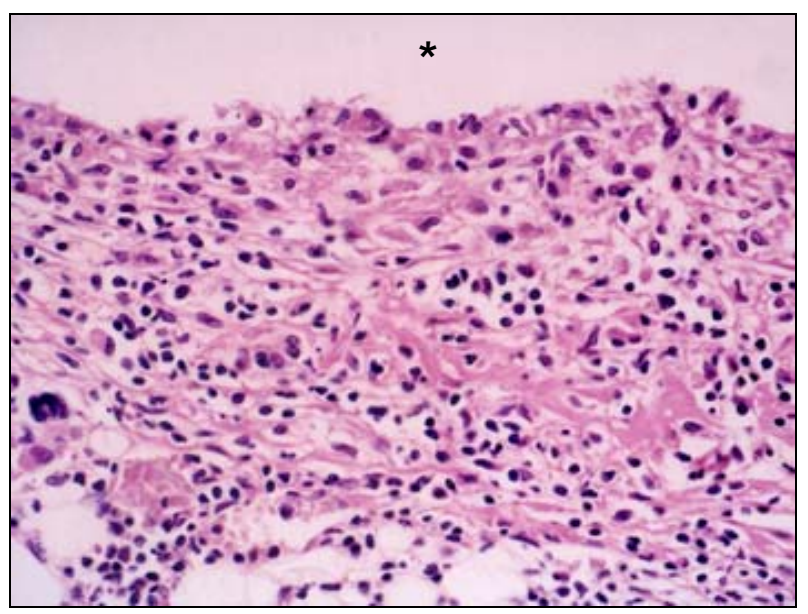

Fig. 15.2 - Fotomicrografia do tecido de granulação com infiltrado inflamatório moderado e organização frouxa das fibras colágenas - 30 dias - aumento $40 X$

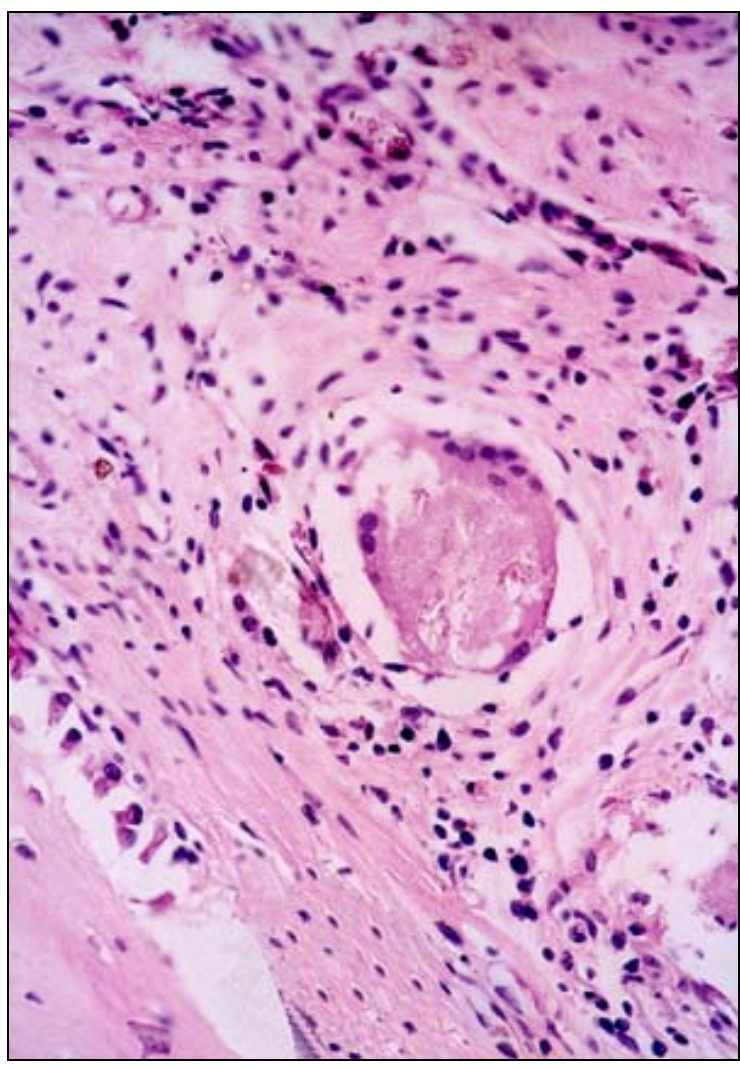

Fig. 16.1 - Fotomicrografia evidenciando células gigantes multinucleadas - Pasta zinco-enólica acrescida de hidróxido de cálcio e subnitrto de bismuto, aos 30 dias - (aumento 40X)

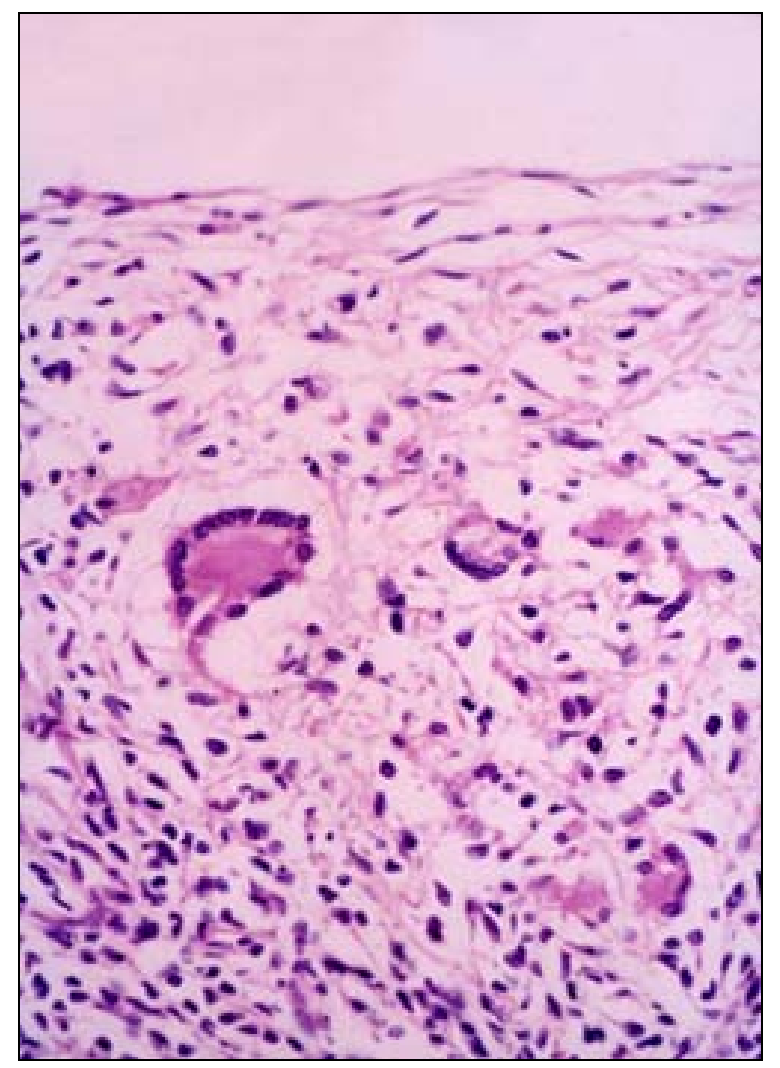

Fig. 16.2 - Fotomicrografia evidenciando células gigantes multinucleadas do tipo Langhans - Pasta zinco-enólica acrescida de subnitrado de bismuto, aos30 dias - aumento 40X) 


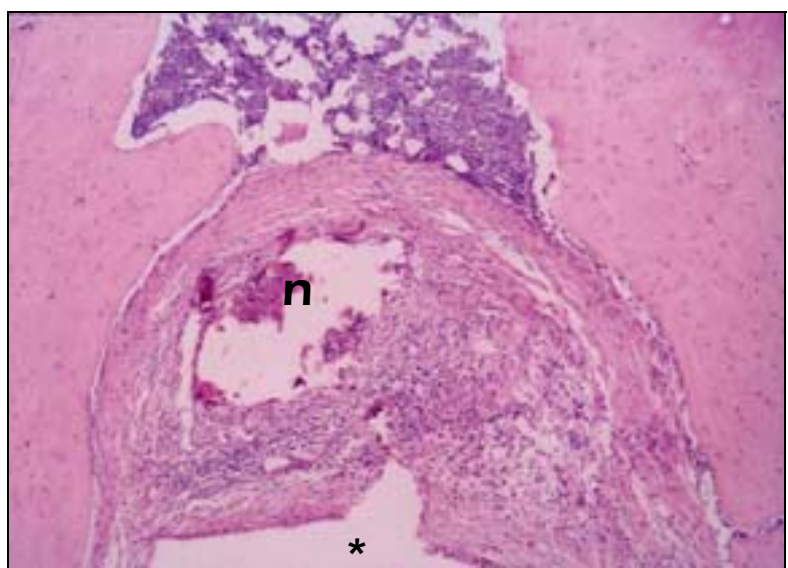

Fig. 17.1 - Fotomicrografia da reação tecidual, aos 30 dias, à pasta zinco-enólica acrescida de iodofórmio. Observar a zona de necrose tecidual (n) no centro do tecido de granulação - aumento $4 X$.

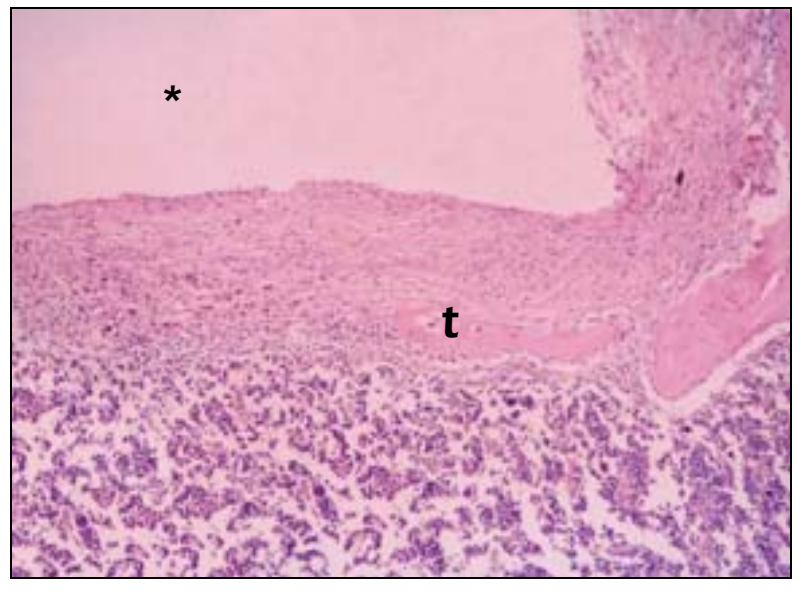

Fig. 18.1 - Fotomicrografia da reação tecidual, aos 30 dias, à pasta zinco-enólica acrescida de iodofórmio e hidróxido de cálcio. Notar a presença de trabéculas(t) à distância do lúmen referente ao tubo(*) - aumento 10X.

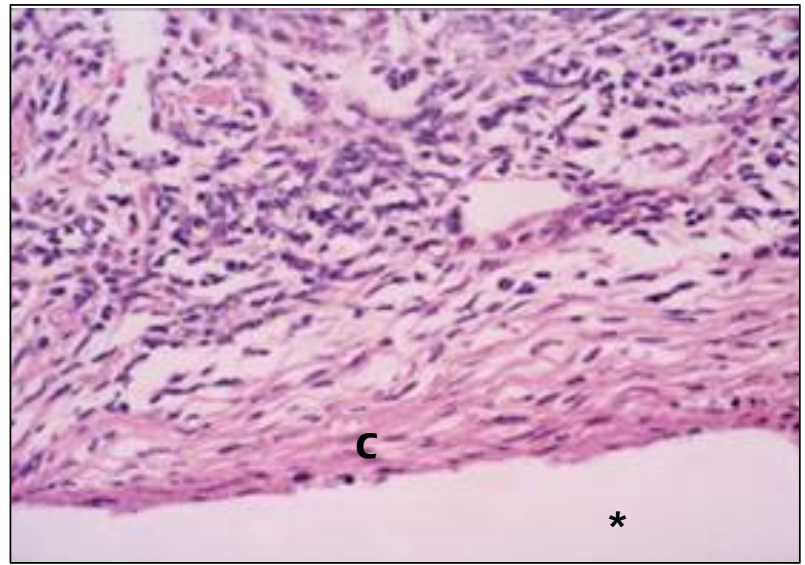

Fig. 17.2 - Fotomicrografia do tecido de granulação, aos 30 dias, denotando infiltrado inflamatório moderado e amadurecimento do tecido de granulação, com formação de cápsula fibrosa (c) na interface com a luz do túbo $\left(^{*}\right)$ - aumento 40X.

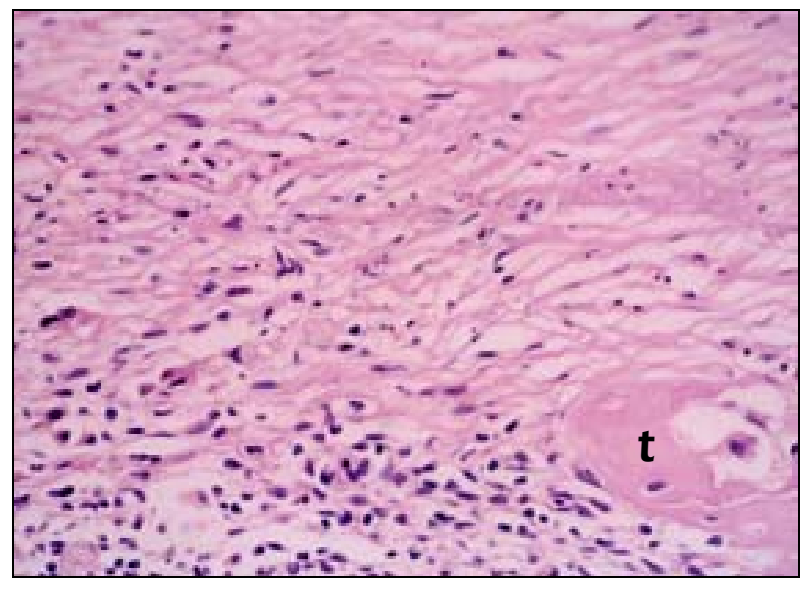

Fig. 18.2 - Fotomicrografia do tecido de granulação evidenciando infiltrado inflamatório moderado e organização frouxa dos feixes de fibras colágenas. Verificar os osteócitos in situ no interior da trabécula (t) - aumento 40X. 
5.2. Avaliação Descritiva Subjetiva dos Achados Microscópicos Relativos ao Período de Sessenta Dias

Controle: Tecido conjuntivo fibroso neoformado projetando-se para o interior do implante, envolvendo delgada trabécula de tecido ósseo, oriundo da parede óssea do receptáculo (Fig. 19.1). Esta delgada trabécula de tecido ósseo está em contato direto com o tecido medular e, o tecido fibroso que a envolve, apresenta-se em fase de maturação, rico em fibras colágenas e ausência de reação inflamatória (Fig. 19.2).

Trióxido mineral agregado: $O$ tecido em contato com o material é ósseo trabeculado (Fig. 20.1), tendo de permeio tecido conjuntivo bem celularizado com feixes colágenos e infiltrado inflamatório crônico discreto com alguns macrófagos esparsos (Fig. 20.2).

Pasta zinco-enólica acrescida de subnitrato de bismuto: Na extremidade do implante, observa-se uma camada de tecido de granulação, assentado sobre uma estrutura neoformada, bem delimitada, a qual contata o tecido medular (Fig. 21.1). O tecido de granulação, em contato com o cimento, mostra infiltrado inflamatório crônico moderado do tipo linfo-histio-plasmocitário (Fig. 21.2), com algumas células gigantes multinucleadas, do tipo corpo estranho, no entremeio. 
Pasta zinco-enólica acrescida de subnitrato de bismuto e hidróxido de cálcio: A extremidade do implante revela tecido conjuntivo de aspecto denso assentado em trabéculas de tecido ósseo (Fig. 22.1). Trata-se de tecido de granulação, em fase de maturação, com fibras colágenas organizadas e pouco celularizado, com infiltrado inflamatório discreto onde macrófagos aparecem de forma dispersa. Nota-se ponte de tecido mineralizado separando a medula óssea do tecido fibroso (Fig. 22.2).

Pasta zinco-enólica acrescida de iodofórmio: Tecido de granulação projetando-se para a luz do implante, com trabéculas de tecido ósseo separando-o do tecido medular (fig. 9.2.9). O tecido de granulação apresenta-se em fase de amadurecimento, com fibras colágenas e proliferação de fibroblastos, infiltrado inflamatório crônico moderado com predomínio de macrófagos, resquícios de necrose na superfície de contado do material e, trabéculas de tecido ósseo neoformadas separando quase que completamente o tecido de granulação do tecido medular (Fig. 9.2.10).

Pasta zinco-enólica acrescida de iodofórmio e hidróxido de cálcio: A extremidade do implante denota tecidos de granulação e ósseo neoformado (Fig 9.2.11). O tecido de granulação apresenta-se em fase de maturação, com fibras colágenas e rico em fibroblastos, infiltrado inflamatório crônico moderado com predominância de macrófagos, partículas extravasadas do material e remanescentes áreas de necrose. Tecido ósseo bem definido separando o tecido de granulação do tecido medular (Fig. 9.2.12). 


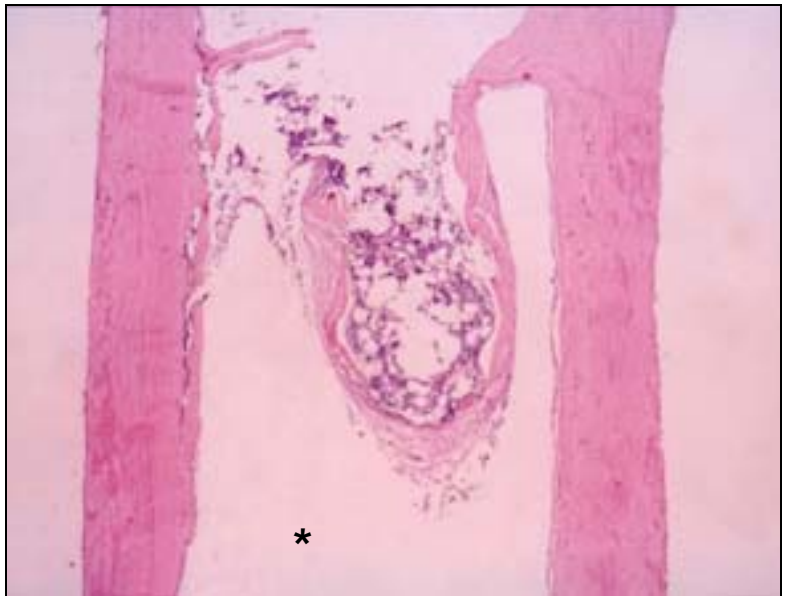

Fig. 19.1- Fotomicrografia da reação tecidual dos tubos vazios aos 60 dias. Observar a invaginação do tecido medular para o interior do espaço referente ao implante $\left({ }^{*}\right)$ - aumento $4 X$.

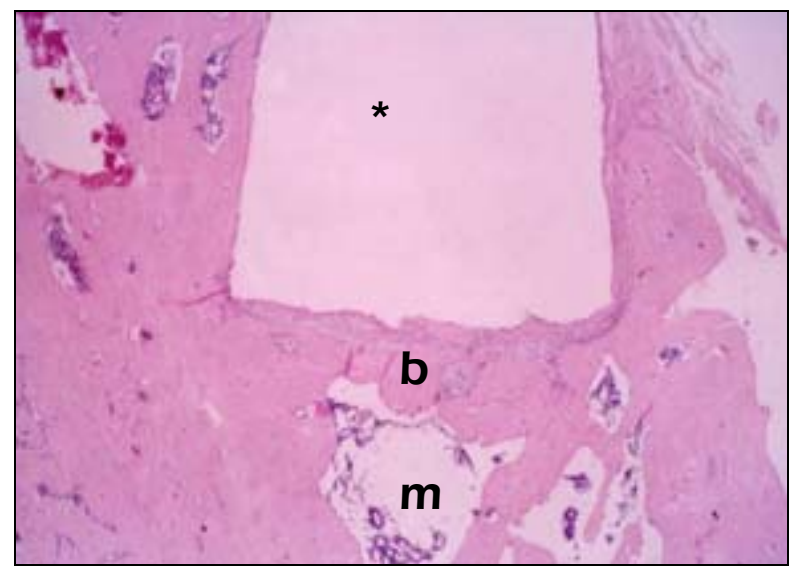

Fig. 20.1 - Fotomicrografia da reação tecidual do trióxido mineral agregado aos 60 dias. Notar a separação do tecido medular $(\mathrm{m})$ e espaço referente ao tubo $\left({ }^{*}\right)$ por tecido mineralizado $(\mathrm{b})$ aumento $4 X$.

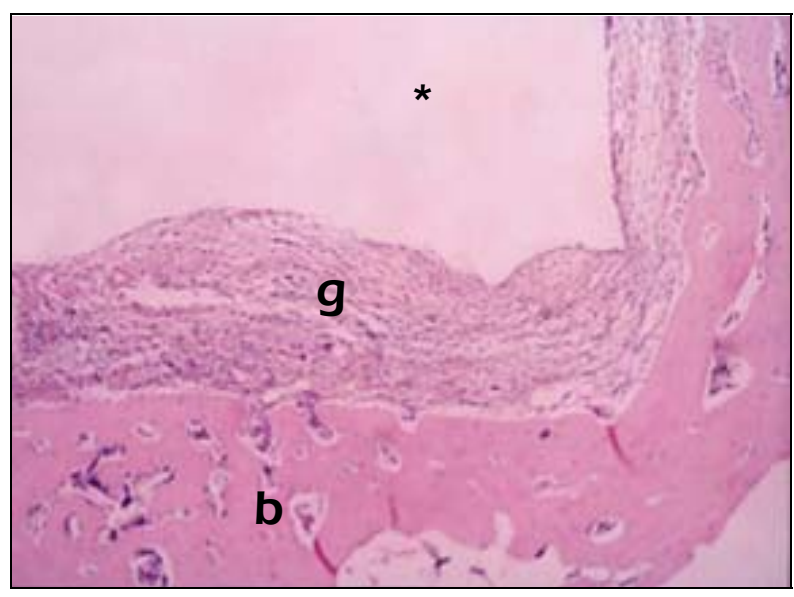

Fig. 21.1 - Fotomicrografia da reação tecidual à pasta zinco-enólica acrescida de subnitrato de bismuto, aos 60 dias. Observar a espessura do tecido de granulação $(g)$ e a barreira de tecido osteóide subjacente (b) - aumento 10X.

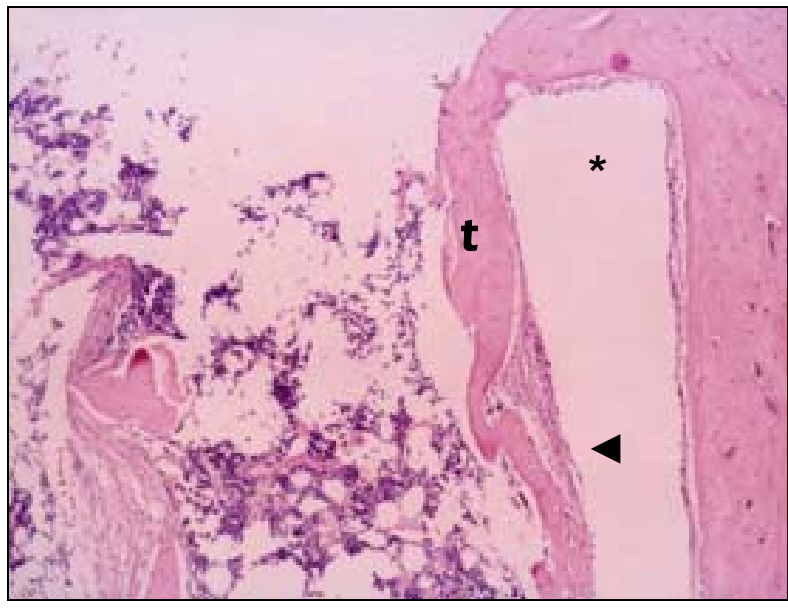

Fig. 19.2 - Fotomicrografia aproximada denotando a neoformação óssea (t) no interior do tubo e limitada do contato a parede deste $(*)$ por delgada cápsula de fibras colágenas (seta) - 60 dias aumento 10X.

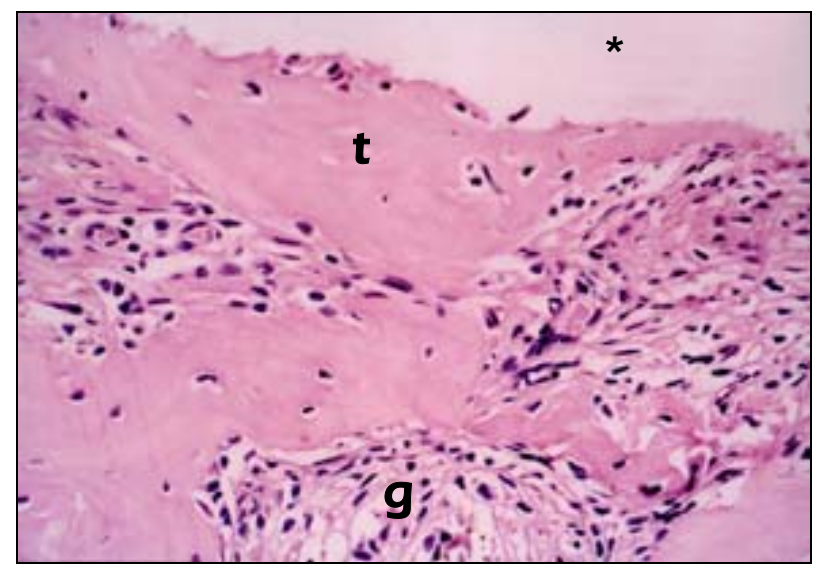

Fig. 20.2 - Fotomicrografia do local de contato do agregado trióxido mineral com o tecido medular, demonstrando a presença de trabéculas ósseas (t) e tecido de granulacão desprovido de células inflamatórias $(g)$ - 60 dias - aumento 40X.

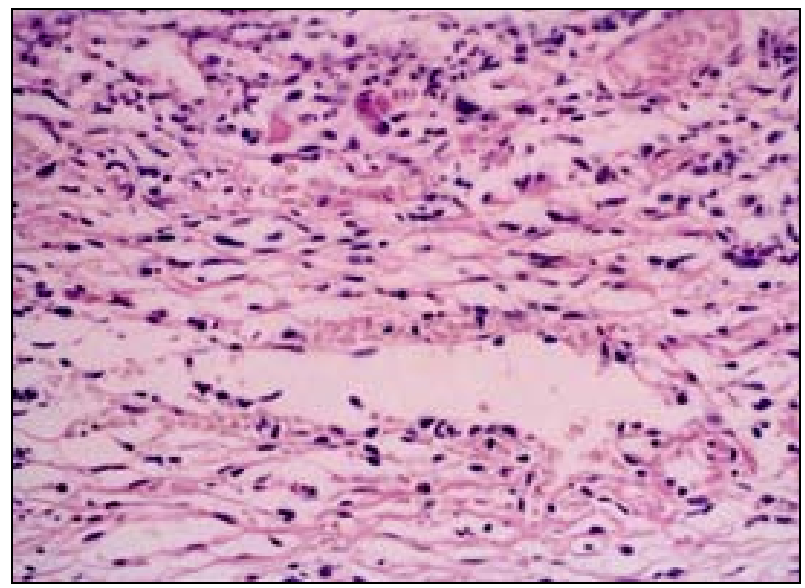

Fig. 21.2 - Fotomicrografia do tecido de granulação dotado de infiltrado inflamatório crônico leve e fibras colágenas organizadas de forma frouxa - aumento $40 X$. 


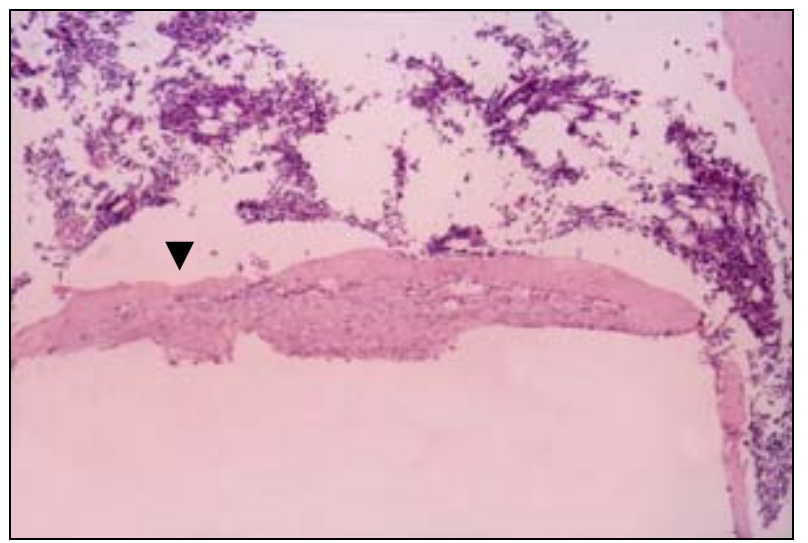

Fig. 22.1 - Fotomicrografia da reação tecidual à pasta zinco-enólica acrescida de subnitrato de bismuto e hidróxido de cálcio, aos 60 dias. Notar a presença de barreira óssea completa separando o delgado tecido de granulação da medula óssea aumento $4 X$.

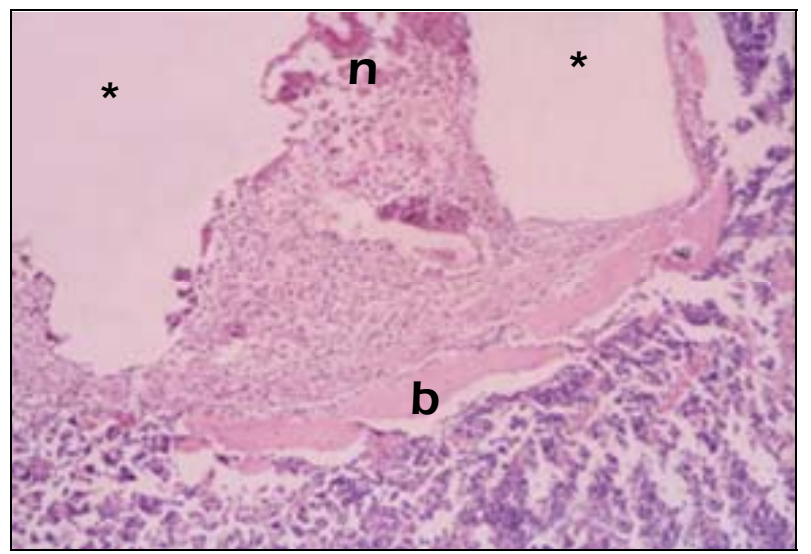

Fig. 23.1 - Fotomicrografias da reação tecidual, aos 60 dias, da pasta zinco-enólica acrescida de iodofórmio. Notar a área de necrose (n) na interface do tecido com o material. Neoformação óssea à distância recobrindo mais de 50\% da superfície do tubo (b) - aumento 4X.

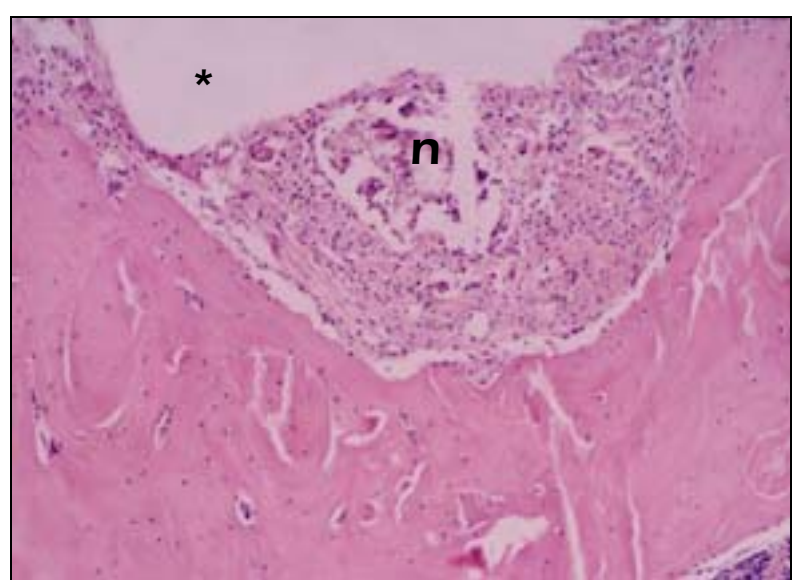

Fig. 24.1 - Fotomicrografia da reação tecidual, aos 60 dias, à pasta zinco-enólica acrescida de iodofórmio e hidróxido de cálcio. Notar a presença de áreas de necrose (n) próximas ao espaço preenchido pelo tubo $\left(^{*}\right)$ - aumento $4 X$.

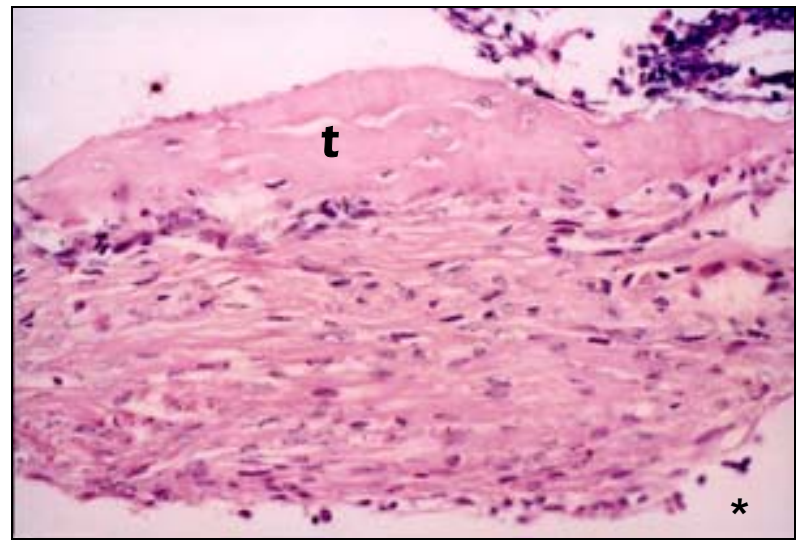

Fig. 22.2 - Fotomicrografia do tecido de granulação demonstrando o infiltrado inflamatório leve e a justaposição das fibras colágenas. Trabécula óssea na divisa com o tecido medular (t) - 60 dias aumento 40X

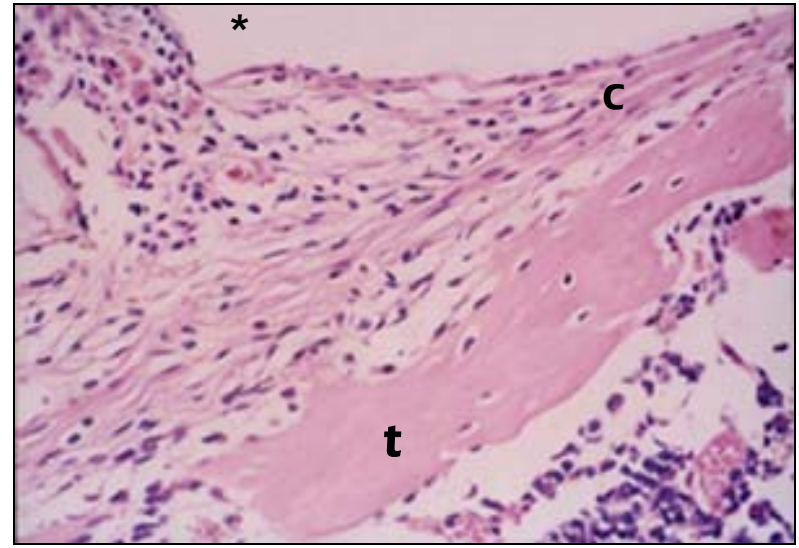

Fig. 23.2 - Fotomicrografia aproximada (40X) do tecido de granulação. Observar a organização dos feixes de fibras colágenas integrantes da cápsula (c), o infiltrado inflamatório leve e a presença de trabécula circunvizinha ao tecido medular (t) - 60 dias - aumento 40X.

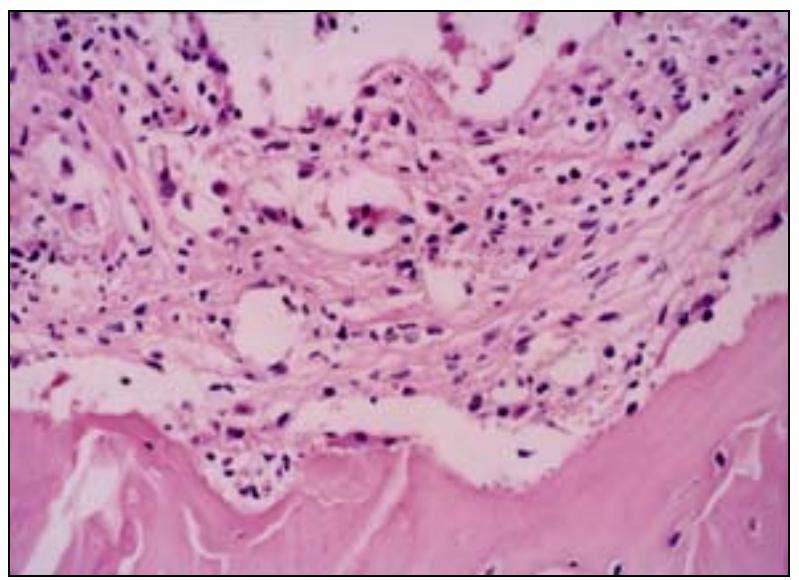

Fig. 24.2 - Fotomicrografia do tecido de granulação em fase de amadurecimento revelando infiltrádo inflamatório leve e fibras colágenas densas não modeladas - 60 dias - aumento 40X 
5.3. Avaliação Descritiva Subjetiva dos Achados Microscópicos Relativos ao Período de Noventa Dias

Controle: Na extremidade do implante há formação de tecido ósseo, a partir do osso circunjacente, envolvendo tecido conjuntivo fibroso, projetando-se para o interior da luz do tubo (Fig. 25.1).

tecido conjuntivo é predominantemente fibroso e está em íntimo contato com a trabécula de tecido ósseo neoformado que o envolve (Fig. 25.2).

Trióxido mineral agregado: A extremidade do implante revela uma fina camada de tecido de granulação assentado em trabéculas espessas de tecido ósseo, oriundas do osso adjacente, cujo processo de formação está incompleto (Fig. 26.1). O tecido de granulação apresenta-se em fase de maturação, o infiltrado inflamatório é discreto e o tecido ósseo mostra-se com aspecto de intensa atividade de desenvolvimento (Fig. 26.2).

Pasta zinco-enólica acrescida de subnitrato de bismuto: $\bigcirc$ vértice do tubo revela uma camada de tecido de granulação moldado sobre trabécula de tecido ósseo, oriunda do osso circunvizinho, separando-o do tecido medular (Fig. 27.1). Este tecido de granulação está em ativo processo de amadurecimento, e apresenta-se rico em fibras colágenas e pouco celularizado. A reação inflamatória encontra-se ausente e o tecido ósseo mostra-se em atividade de formação (Fig. 27.2). 
Pasta zinco-enólica acrescida de subnitrato de bismuto e hidróxido de cálcio: A extremidade do implante evidencia camada de tecido de granulação assentada em trabéculas de tecido ósseo neoformado, oriundas do osso circunjancente, as quais separam, de modo incompleto, o tecido medular (Fig. 28.1). $\bigcirc$ tecido de granulação apresenta-se em fase de maturação, com infiltrado inflamatório crônico moderado (Fig. 28.2).

Pasta zinco-enólica acrescida de iodofórmio: Na extremidade dos tubos implantes preenchidos observa-se camada de tecido de granulação superposto à trabéculas que separam quase completamente este do tecido medular (Fig. 29.1). O tecido de granulação apresenta-se em fase de maturação, celularizado por fibroblastos, e o infiltrado inflamatório é considerado discreto (Fig. 29.2).

Pasta zinco-enólica acrescida de iodofórmio e hidróxido de cálcio: A extremidade do implante revela camada de tecido de granulação seguida de trabéculas ósseas esparsas, que não separam totalmente o tecido medular (Fig. 30.1) do tecido de granulação, o qual encontra-se em fase de maturação com moderado infiltrado inflamatório crônico e trabécula óssea, sugerindo atividade formadora (Fig. 30.2). 


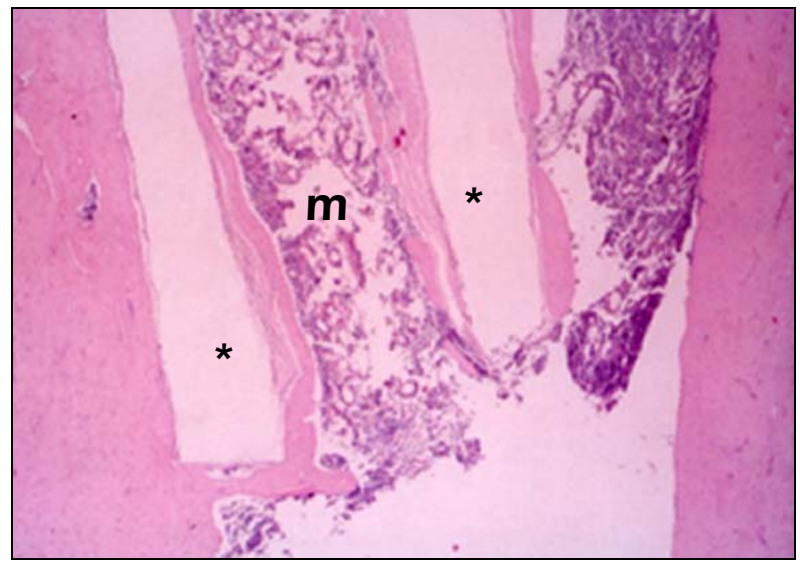

Fig. 25.1 - Fotomicrografia da reação tecidual dos tubos vazios, no período de 90 dias. Notar o tecido medular invaginado $(\mathrm{m})$ e limitado pelo espaço relativo às paredes do implante $\left({ }^{*}\right)$ নl Imentn $4 X$

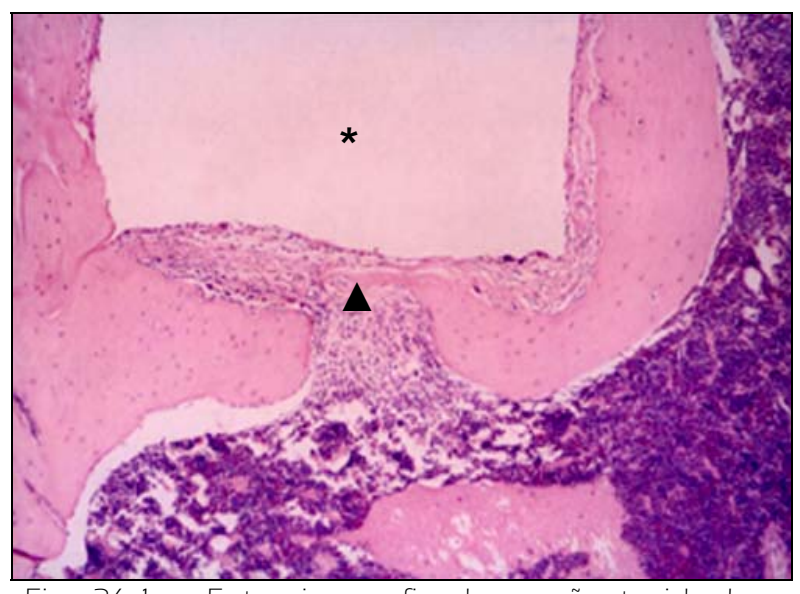

Fig. 26.1 - Fotomicrografia da reação tecidual ao agregado de trióxido mineral aos 90 dias. Observar a centralidade da trabécula óssea (seta), próxima ao local ocupado pelo cimento $\left(^{*}\right)$ - aumento 4X.

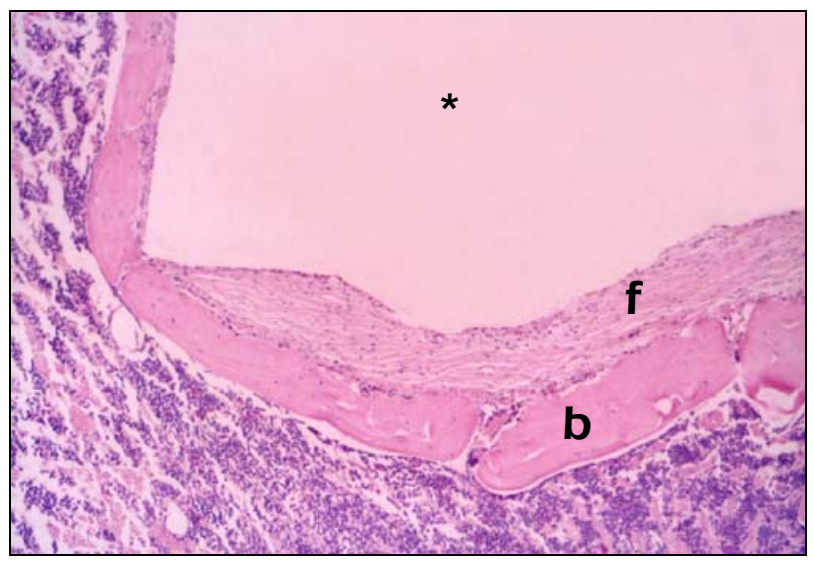

Fig. 27.1 - Fotomicrografias da reação tecidual à pasta zinco-enólica acrescida de subnitrato de bismuto, aos 90 dias. Observar a espessura da cápsula fibrosa (f) e sua separação do tecido medular por barreira osteóide completa (b) aumento $4 X$.

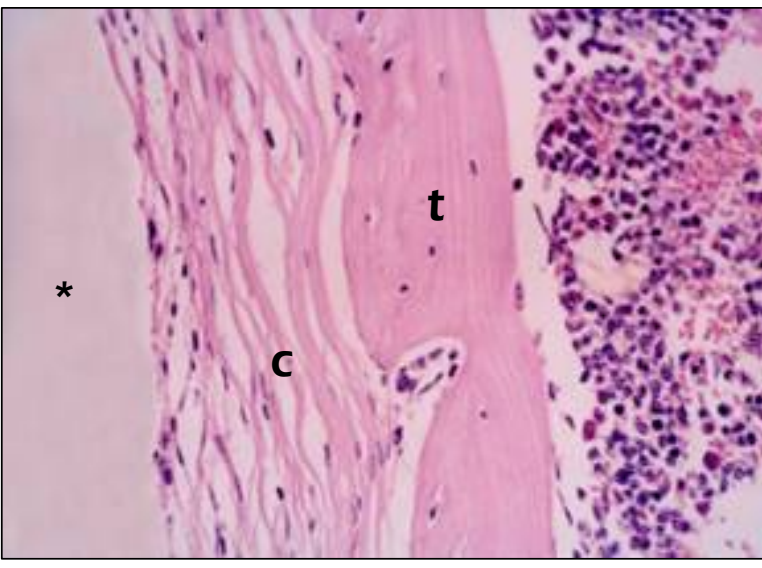

Fig. 25.2 - Fotomicrografias aproximada (40X) da interface entre as trabéculas ósseas (t), cápsula fibrosa (c) e espaço referente à parede do tubo (*) -90 dias.

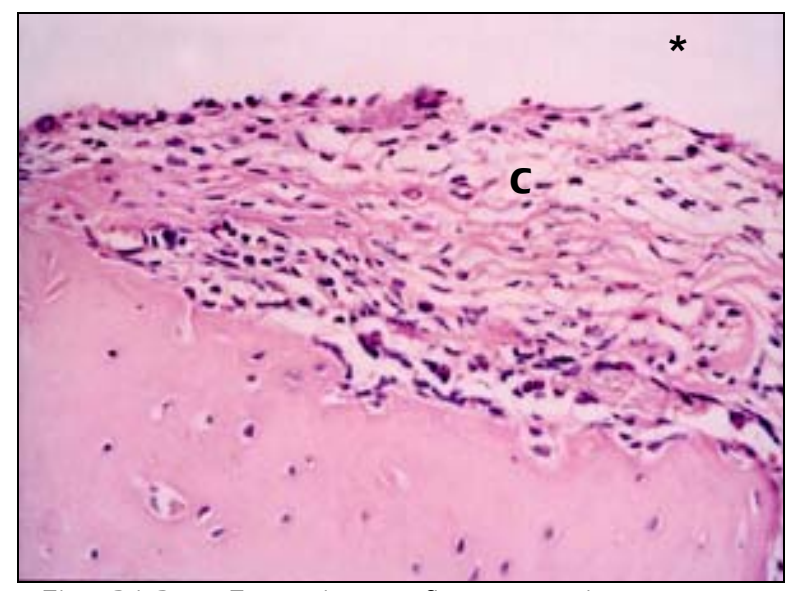

Fig. 26.2 - Fotomicrografia em maior aumento mostrando a cápsula fibrosa em contato com o lúmen referente ao implante(*). Observar a ausência de células inflamatórias e conformação não densa das fibras colágenas (c) - 90 diás aumento 40X.

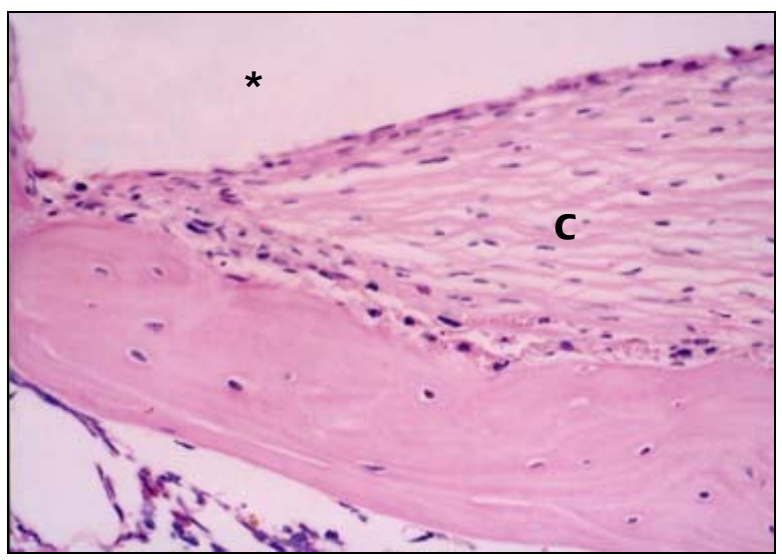

Fig. 27.2 - Fotomicrografia aproximada da reação tecidual denotando a ausência de células inflamatórias e a justaposição e organização do feixes de fibras colágenas (c) - aumento 40X́. 


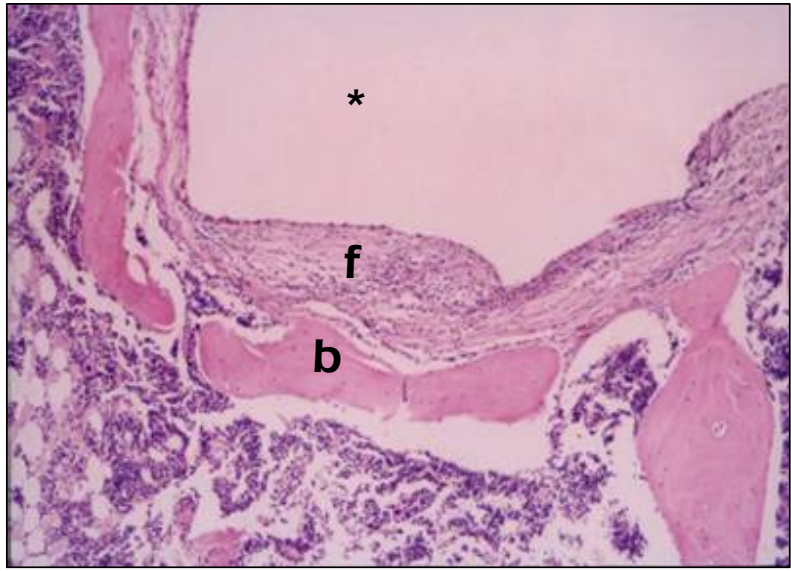

Fig. 28.1 - Fotomicrografia da reação tecidual à pasta zinco-enólica acrescida de subnitrato de bismuto e hidróxido de cálcio, aos 90 dias. Notar a cápsula fibrosa espessa (f) e a separacão com o tecido medular quase completa (b) - aumento 4X.

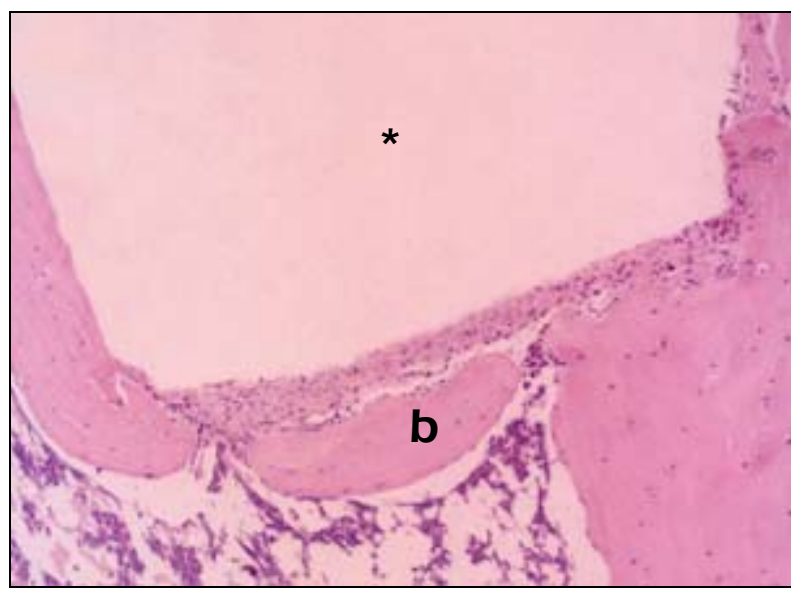

Fig. 29.1 - Fotomicrografia da reação tecidual, aos 90 dias, à pasta zinco-enólica acrescida de iodofórmio. Observar a reduzida espessura da cápsula fibrosa situada entre barreira osteóide (b) e espaço referente ao implante $\left(^{*}\right)$ - aumento $4 X$.

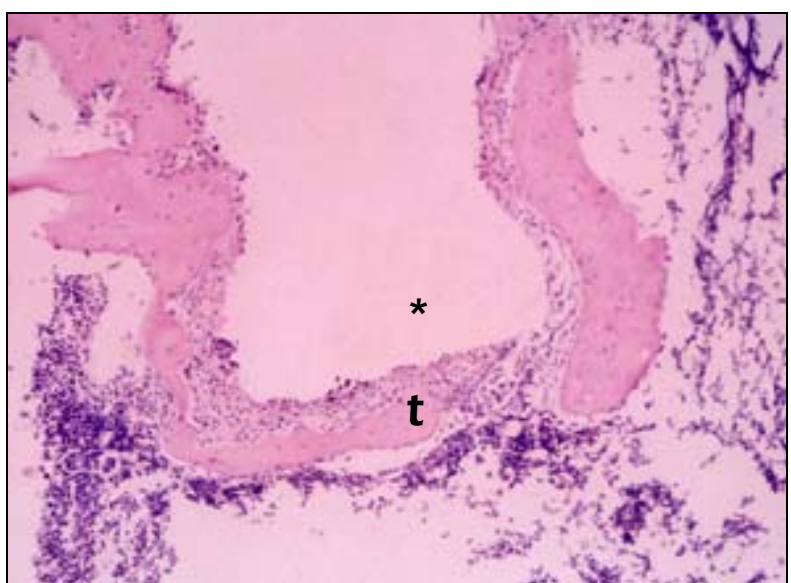

Fig. 30.1 - Fotomicrografia da reação tecidual, aos 90 dias, à pasta zinco-enólica acrescida de iodofórmio e hidróxido de cálcio. Observar a neoformação óssea à distância (t) obliterando mais de 50\% do espaço referente à extremidade do tubo $\left.{ }^{*}\right)$ - aumento $4 X$.

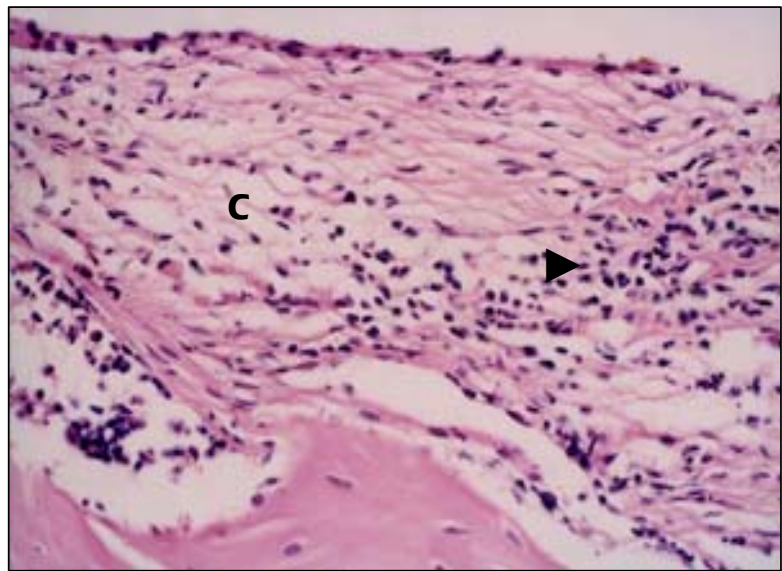

Fig. 28.2 - Fotomicrografia aproximada da cápsula fibrosa evidenciando a organização não-densa dos feixes de fibras colágenas (c) e a presença de infiltrado inflamatório leve (seta) - 90 dias - aumento $40 X$

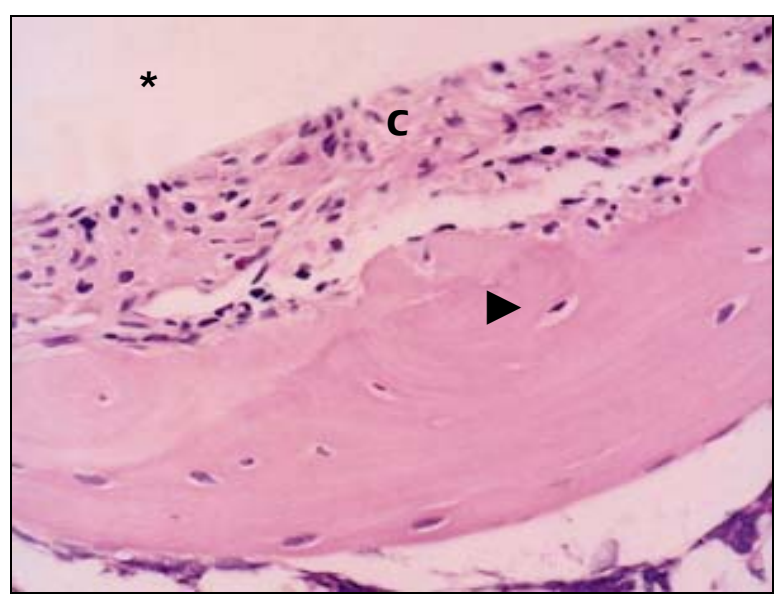

Fig. 29.2 - Fotomicrografia em maior aumento dos fenômenos teciduais. Notar a densidade da cápsula fibrosa (c), a ausência de células inflamatórias e, na trabécula óssea, a presença de osteócito in situ (seta) - 90 dias - aumento 40X.

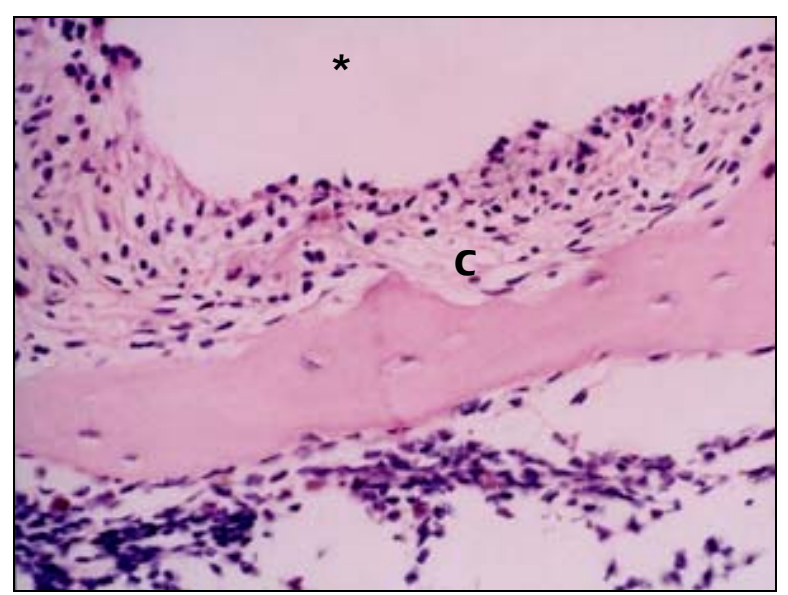

Fig. 30.2 - Fotomicrografia da inteface de contato do implante com o tecido de granulação delgado (c) - 90 dias - aumento 40X. 


\subsection{Análise Estatística}

Os dados obtidos em cada categoria foram submetidos á análise de variância não-paramétrica global (KRUSKAL WALLIS) e, quando da presença de diferenças significativas entre os grupos, os mesmos foram comparados pelos métodos de comparações múltiplas (Teste de DUNN e Teste de MILLER) além da comparação dois a dois (Teste MANN WHITNEY) com nível de significância de 5\%. A seguir relatamos as diferenças estatísticas significantes após comparações dos grupos em cada período experimental e entre os diferentes períodos. Os detalhes numéricos específicos dos cálculos são especificados nos anexos de H à Y.

Tabela 20 - Demonstrativo dos resultados significantes obtidos através da análise de variância entre os grupos, dentro de cada período experimental $(\mathrm{p} \leq 0.05)$.

\begin{tabular}{|c|c|c|c|}
\hline & 30 dias & 60 dias & 90 dias \\
\hline Infiltrado Inflamatório & $\begin{array}{l}\text { Grupo } 4 \times \text { Controle } \\
\text { Grupo } 3 \times \text { Controle } \\
\text { Grupo } 2 \times \text { Controle } \\
\text { Grupo } 1 \times \text { Controle } \\
\text { Grupo } 4 \times \text { Grupo } 5 \\
\text { Grupo } 3 \times \text { Grupo } 5 \\
\text { Grupo } 2 \times \text { Grupo } 5 \\
\text { Grupo } 1 \times \text { Grupo } 5\end{array}$ & - & $\begin{array}{l}\text { Grupo } 4 \times \text { Controle } \\
\text { Grupo } 2 \times \text { Controle }\end{array}$ \\
\hline Células Gig. Multinucl.eadas & - & - & - \\
\hline Necrose Tecidual & $\begin{array}{l}\text { Grupo } 4 \times \text { Grupo } 5 \\
\text { Grupo } 3 \times \text { Grupo } 5 \\
\text { Grupo } 4 \times \text { Controle } \\
\text { Grupo } 3 \times \text { Controle }\end{array}$ & - & - \\
\hline Organização Tec. Granulação & Grupo 3 X Controle & - & - \\
\hline Trabéculas ósseas adjacentes & $\begin{array}{l}\text { Grupo } 4 \times \text { Controle } \\
\text { Grupo } 4 \times \text { Grupo } 5 \\
\text { Grupo } 3 \times \text { Grupo } 5\end{array}$ & - & $\begin{array}{l}\text { Grupo } 4 \times \text { Controle } \\
\text { Grupo } 3 \times \text { Controle }\end{array}$ \\
\hline Barreira ósteóide completa & - & - & - \\
\hline
\end{tabular}

- estatisticamente não significante 
Tabela 21 - Demonstrativo dos resultados significantes obtidos através da análise de variância de cada grupo nos diversos períodos experimentais ( $p \leq 0.05$ ).

\begin{tabular}{|c|c|c|c|}
\hline & $30 \times 60$ dias & $30 \times 90$ dias & $60 \times 90$ dias \\
\hline Grupo 1 & & $\begin{array}{l}\text { Infiltrado Inflamatório } \\
\text { Organiz. Tec. Granul }\end{array}$ & - \\
\hline Grupo 2 & - & Infiltrado Inflamatório & - \\
\hline Grupo 3 & - & $\begin{array}{c}\text { Infiltrado Inflamatório } \\
\text { Necrose Tecidual } \\
\text { Organiz. Tec. Granul }\end{array}$ & - \\
\hline Grupo 4 & $\begin{array}{l}\text { Infiltrado Inflamatório } \\
\text { Organiz. Tec. Granul. }\end{array}$ & $\begin{array}{c}\text { Infiltrado Inflamatório } \\
\text { Necrose Tecidual } \\
\text { Organiz. Tec. Granul }\end{array}$ & - \\
\hline Grupo 5 & - & घ & - \\
\hline Controle & - & - & $\square$ \\
\hline
\end{tabular}

- estatisticamente não significante

5.5 Gráficos Comparativos das Médianas Relativas aos Fenômenos Inflamatórios e Osteogênicos

Tabela 22 - Legenda explicativa para distinção dos grupos nos gráficos comparativos.

\begin{tabular}{|c|c|c|c|c|c|}
\hline Grupos & 1 & 2 & 3 & 4 & 5 \\
\hline Pasta Zinco-Enólica & $x$ & $x$ & $x$ & $x$ & \\
\hline lodofórmio (20\%) & $X$ & & $x$ & & \\
\hline Subn. de Bism. (20\%) & & $X$ & & $x$ & \\
\hline Hidróxlido de Cálcio (20\%) & & & $x$ & $x$ & \\
\hline Glicerina & $x$ & $x$ & $x$ & $x$ & \\
\hline Agregado Trióxido Mineral & & & & & $x$ \\
\hline Água Destil. (25\%) & & & & & x \\
\hline
\end{tabular}




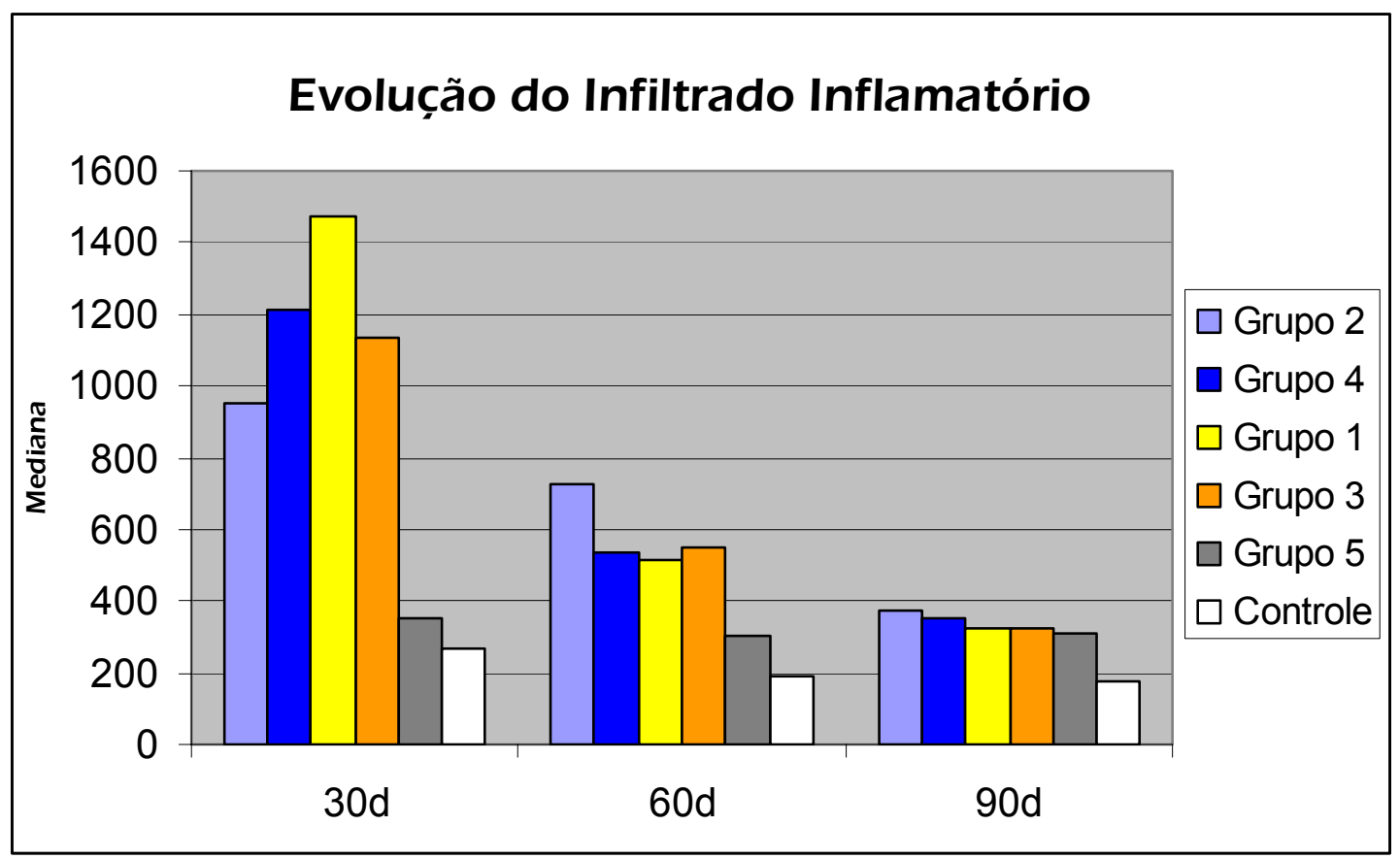

Figura 31 - Gráfico representativo da evolução do infiltrado celular inflamatório no decorrer dos períodos experimentais.

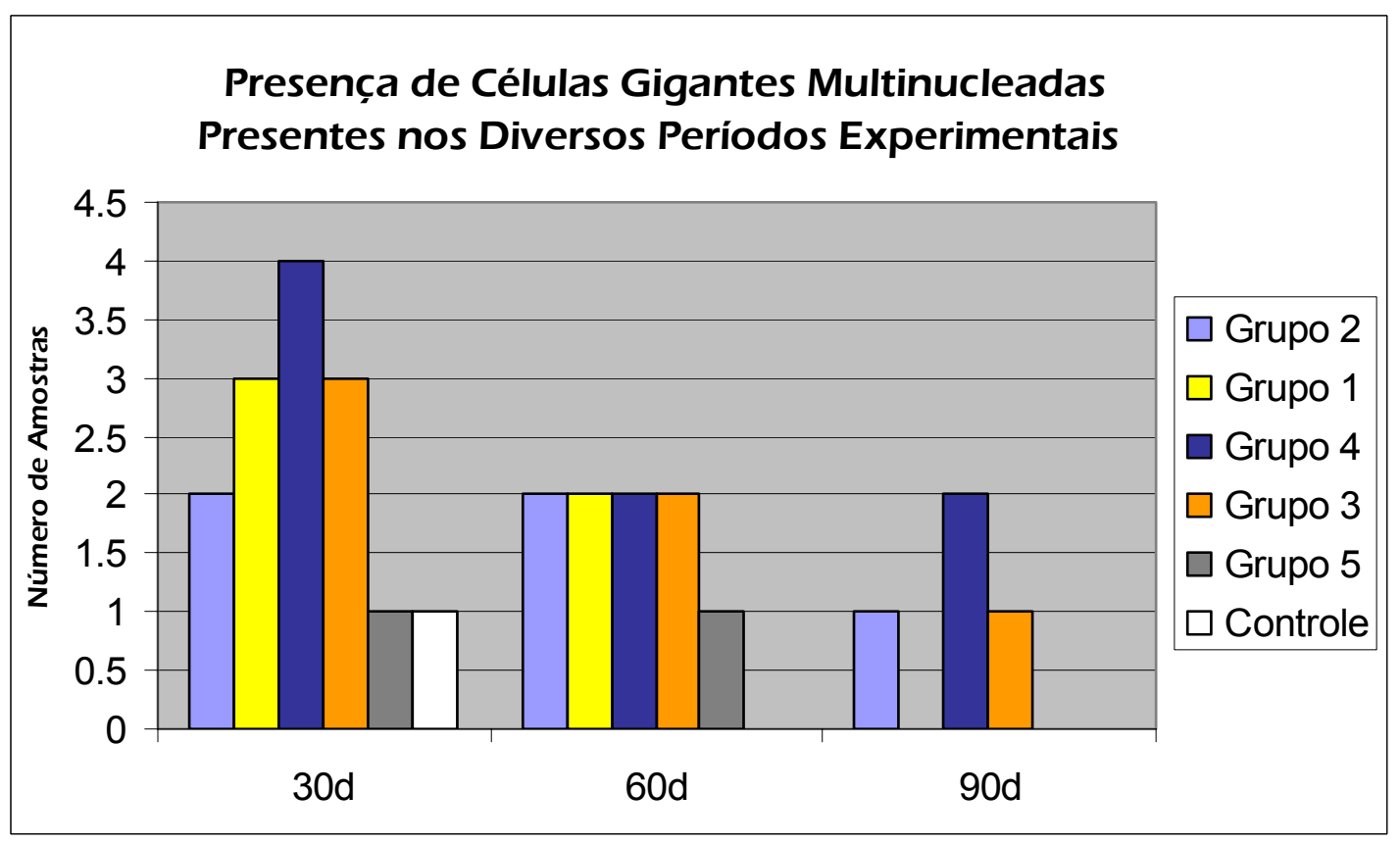

Figura 32 - Gráfico demonstrativo da quantidade de amostras com células gigantes multinucleadas presentes, no decorrer dos períodos experimentais 


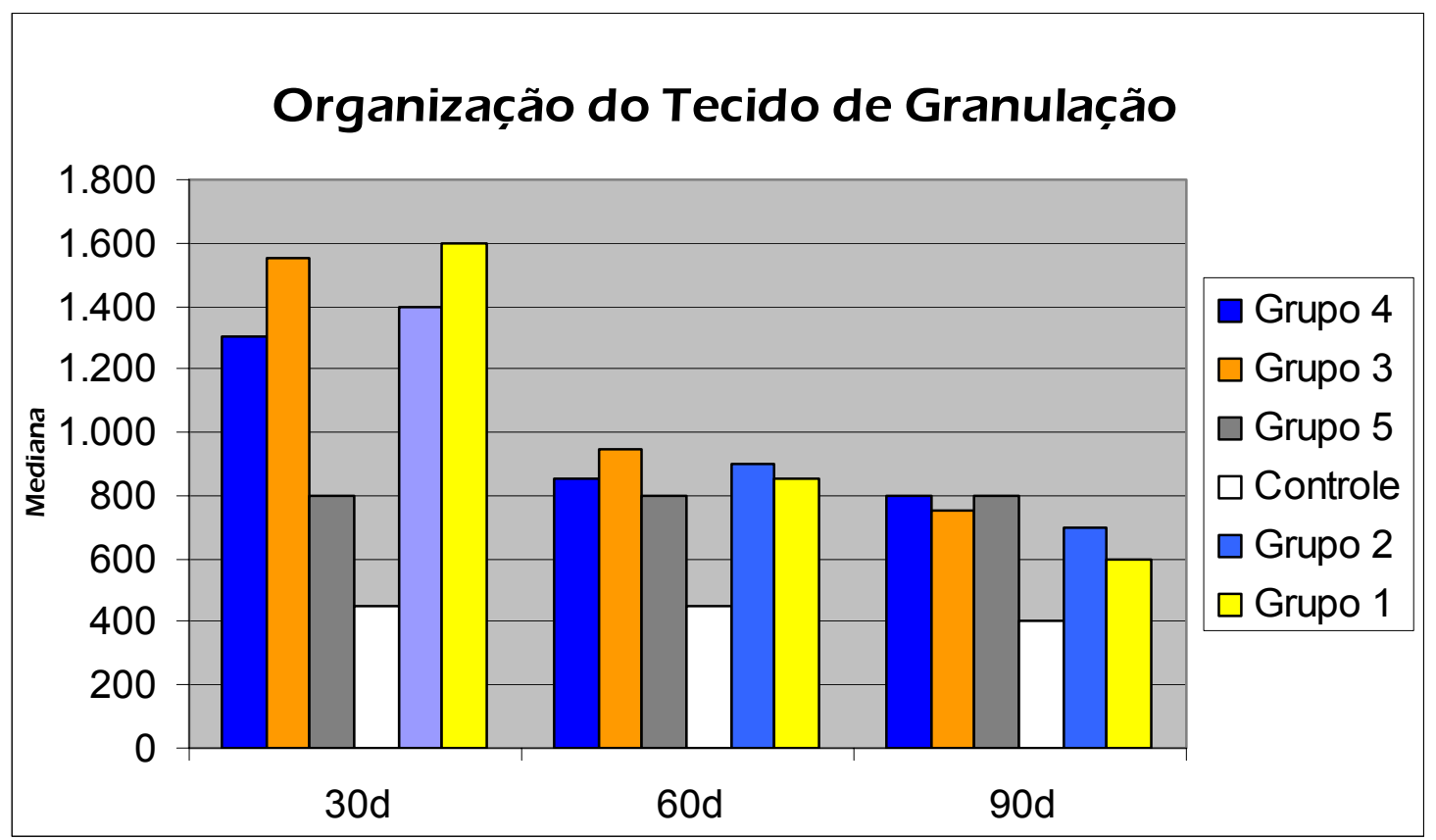

Figura 33 - Gráfico referente à evolução da organização do tecido de granulação, nos diferentes períodos experimentais.

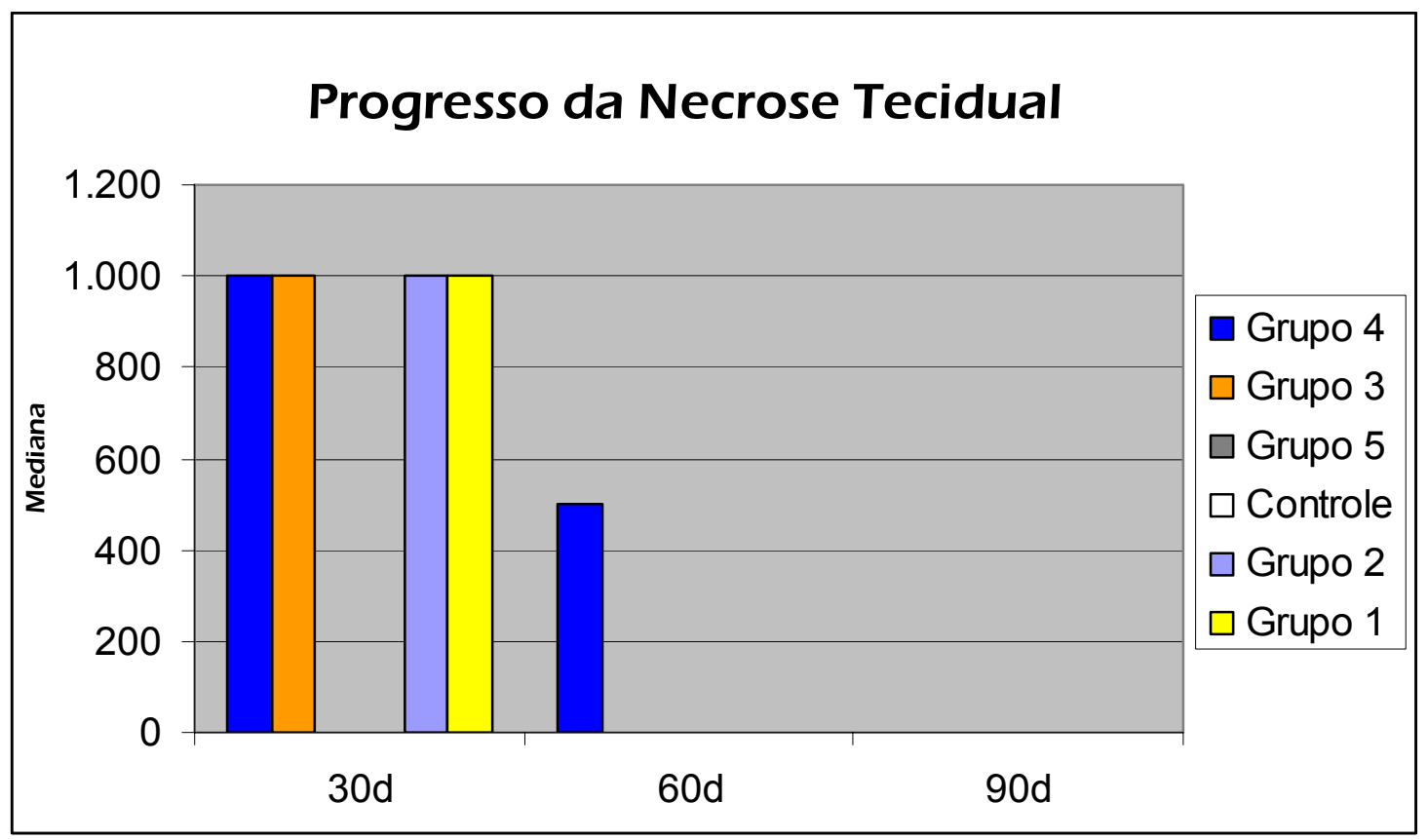

Figura 34 - Gráfico demonstrativo da presença de necrose de coagulação nos diversos grupos em cada período experimental. 


\section{Distribuição do Número de Amostras com Trabéculas Ósseas Adjacentes}

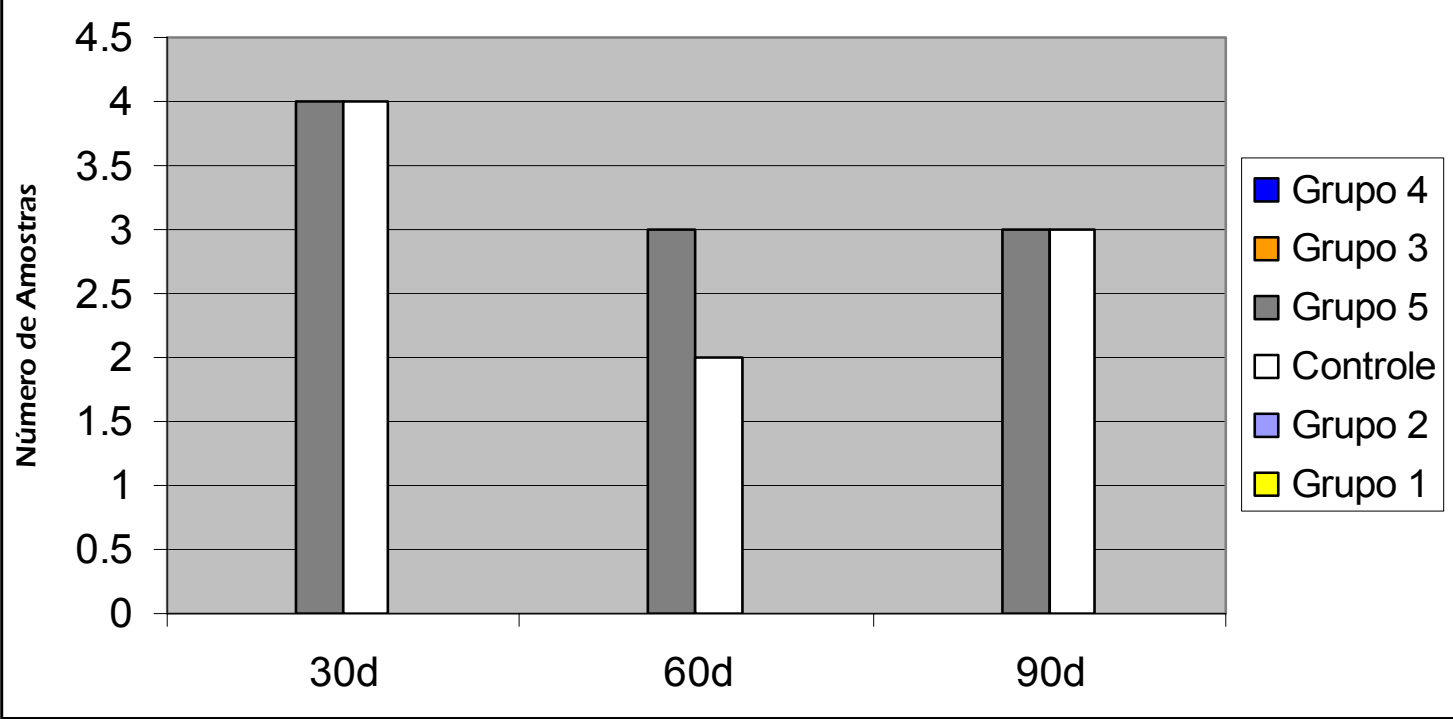

Figura 35 - Grafico representativo da presença de tecido duro neoformado na interface do tubo com o tecido medular, nos diferentes intervalos experimentais.

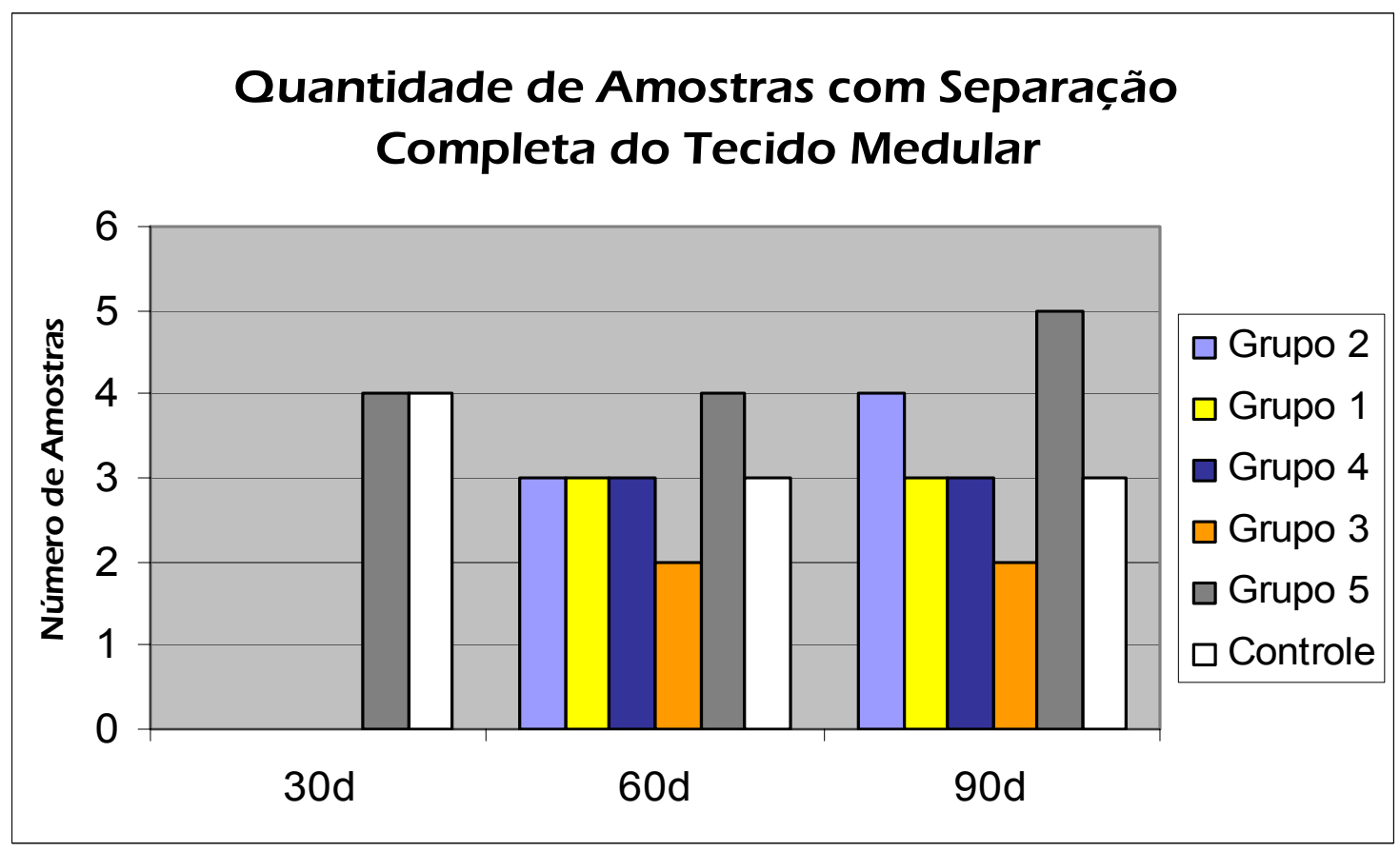

Figura 36 - Grafico demonstrativo da presença de barreira osteóide completa separando o tecido de granulação do tecido conjuntivo medular, nos diversos períodos experimentais. 
A ciência e o crescimento do conhecimento estão sempre partindo de problemas e talvez terminando em problemas problemas de profundidade sempre crescente e com uma fertilidade sempre crescente para sugerir novos problemas.

Karl Popper

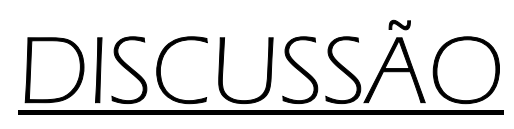




\section{DISCUSSÃO}

\subsection{Dos Materiais Utilizados}

De acordo com a classificação proposta por RAMOS e BRAMANTE ${ }^{86}$, a denominação pasta aplica-se aos materiais obturadores que permanecem por tempo indeterminado sob o mesmo estado físico, diferindo dos cimentos pela necessidade destes serem preparados no momento do uso, endurecendo em seguida. Baseados nestas observações e, conscientes de sua veracidade, qualificamos o material resultante da agregação da pasta LS® com substâncias radiopacificadoras e hidróxido de cálcio como cimento à base de óxido de zinco e eugenol.

A escolha da pasta zinco-enólica para esta pesquisa teve como alicerce os trabalhos de BERNARDINELI ${ }^{7}$ e MORAIS ${ }^{71}$ respectivamente, mostrando a capacidade de vedamento, baixo índice de infiltração aos corantes e reduzida reatividade inflamatória do cimento.

Optamos pela pasta zinco-enólica LS $®$ tipo II em virtude da menor concentração de eugenol (10,25\%) quando comparada á pasta Lysanda® dotada de 18\% deste reagente. Com base nos estudos de HUME ${ }^{50,51}$, ao relacionarmos a concentração do eugenol na pasta com a severidade dos fenômenos inflamatórios teciduais, talvez a diminuta concentração de eugenol da pasta fosse um dos responsáveis pela proximidade daqueles com a quase inércia inflamatória atribuída ao agregado de trióxido mineral. 
A incorporação do hidróxido de cálcio à pasta justificou-se a partir do estudo de BERBERT ${ }^{6}$ que, ao acidionar este composto ao cimento AH26 observou um declínio mais acentuado da reação inflamatória com o passar do tempo, e conseqüentemente formação de barreira óssea apical.

A escolha do iodofórmio e subnitrato de bismuto como agentes radiopacificadores fundamentou-se, primeiramente, no significativo tempo de uso e bons resultados verificados na prática endodôntica, atuando como agentes de contraste radiográfico e antissépticos de pastas ${ }^{64,110,12,25,86}$ e cimentos $^{68,44,12,50,94}$. Em um segundo momento, o potencial radiopacificador conferido especificamente à pasta zinco-enólica mostrou-se mais acentuado do que o produzido por com outros compostos como sulfato de bário e óxido de zinco em pó?.

A adição de 20\% em peso destes agentes foi escolhida por ser a menor proporção a produzir resultados radiográficos equivalentes aos da guta percha', e também por ser a utilizada no trióxido mineral agregado, embora o radiopacificador seja o óxido de bismuto.

BERNARDINELI ${ }^{8}$ confirmou, por meio de microscopia eletrônica de varredura, a ausência de interferência da incorporação de iodofórmio a pasta zinco-enólica Lysanda ${ }^{\circledR}$, com a manutenção dos insignificantes índices de infiltração em cavidades retrógradas, fortalecendo os achados de KUGA, MORAES e BERBERT ${ }^{59}$ sobre a melhora do selamento do cimento Sealapex ${ }^{\circledR}$ quando acrescido de 33\% em peso do pó de iodofórmio.

A necessidade de retardarmos o tempo de presa de um material é uma condição importante para que se possa manipular adequadamente um cimento. A glicerina, por nós escolhida para ser 
acrescentada à pasta zinco-enólica, se mostrou eficiente para este propósito, proporcionando um tempo de trabalho adequado ${ }^{8}$.

segundo OKAMOTO ${ }^{73}$, uma matriz óssea preservada em glicerina a $98 \%$ e posteriormente implantada na tíbia de ratos apresenta um processo de reabsorção e substituição óssea mais rápido, quando comparado ao enxerto convencional. Logo, a glicerina associada à pasta zinco-enólica para estender o tempo de trabalho, poderia influenciar positivamente a reabsorção e neoformação óssea.

Pelo menos para nós, a pasta zinco-enólica tem mostrado características físicas promissoras e compará-la ao trióxido mineral agregado traz subsídios altamente enriquecedores para o seu aprimoramento no critério de compatibilidade tecidual.

$\bigcirc$ trióxido mineral agregado é um cimento bastante pesquisado nos dias de hoje, tanto sobre o ponto de vista biológico quanto químico e físico. Optamos pela sua utilização em função da larga aplicabilidade clínica e principalmente dos excelentes resultados que o mesmo tem demonstrado no selamento de perfurações ${ }^{62}$ ou mesmo em outras aplicações como cimento retrobturador cirúrgico ${ }^{102,103,104}$.

A inexistência de uma substância que preencha todos os requisitos necessários a um material retrobturador faz com que novas pesquisas sejam formuladas, procurando dentro das possibilidades dos diferentes métodos, a desenvoltura de um material ideal ou próximo a isto. 


\subsection{Do Método}

objetivo principal deste experimento foi investigar o comportamento biológico de um material de moldagem que vem sendo estudado como potencial cimento retrobturador, acrescido de aditivos já utilizados na odontologia, que aperfeiçoariam seu uso, dentro de um modelo técnico-científico que se aproximasse da situação encontrada na clínica cirúrgica, onde pudéssemos controlar a presença de fatores externos, para estudar exclusivamente a influência dos materiais sobre a reparação óssea.

Escolhemos o rato de laboratório (Rattus norvegicus) para nosso teste porque o mesmo serve como organismo modelo e oferece inúmeras vantagens como, por exemplo, sensibilidade a um grande número de substâncias tóxicas, facilidade de obtenção, manuseio e armazenagem devido ao tamanho reduzido. Desta forma, o rato é a principal espécie de mamíferos recomendada para estudos “in vivo"62.

A similaridade de 278 segmentos entre o genoma humano e do rato aumenta a probabilidade de que os experimentos de toxicidade executados nestes animais sejam fortes evidências do que ocorre no organismo dos humanos ${ }^{57}$.

A estrutura óssea do rato é similar à de outras espécies de mamíferos, e geralmente o fêmur é utilizado para avaliações microscópicas da medula óssea, que é constituida por um estroma frouxo de tecido conectivo, dotado de células reticulares adventícias, adipócitos, macrófagos e fibras de reticulina as quais sustentam a grande quantidade de vasos e células hematopoiéticas ${ }^{58}$. 
LU et al ${ }^{63}$, embora pesquisando em coelhos, descobriram que o tecido medular mostra uma reação do tipo corpo estranho mais confiável, sensitiva e duradoura quando comparada a outros tecidos ósseos, o que pode ser vantagens para testar compatibilidade tecidual de materiais "in vivo". MORETTON et al ${ }^{72}$ afirmam, embasados em cálculos estatísticos, que a inflamação relacionada aos implantes intraósseos foi menos severa que a subcutânea.

Optamos por realizar a pesquisa em tecido ósseo devido ao potencial osteogênico neste tecido ser duas vezes superior ao encontrado em tecido mole ${ }^{11}$, provavelmente por ser a medula óssea um reservatório de células primordiais envolvidas na hematopoiese e defesa ${ }^{22}$.

Armazenamos os animais por 15 semanas antes do experimento, a fim de que suas estruturas esqueléticas, principalmente a tíbia e o fêmur, atingissem um tamanho adequado que permitisse executar a osteotomia e adaptar completamente os implantes na cavidade medular dos ossos sem que as corticais laterais fossem perfuradas ou exageradamente fragilizadas, desfavorecendo dessa forma a ocorrência de fraturas, que, embora não as desejássemos, ocorreram em 9\% dos espécimes.

Utilizamos, nesta pesquisa, brocas esféricas carbide $n^{0} 6$ novas, as quais serviram de limite transversal na confecção das canaletas, ao passo que o limite longitudinal foi determinado pelo tamanho dos implantes a ser inseridos, aproximadamente $5 \mathrm{~mm}$.

Ao serem introduzidos no interior da cavidade óssea, os implantes permaneciam presos pelas corticais ósseas laterais, de modo que as extremidades dos tubos contatavam a área onde ocorreriam os fenômenos envolvidos no reparo (Figs. 8.1 e 8.2). 
Uma das vantagens da utilização deste método consiste na facilidade de controle da contaminação, proporcionada pela adoção de normas de antissepsia cirúrgica. A padronização da superfície de contato dos materiais, simulando o tamanho de uma cavidade retrógrada, também contribui para a confiabilidade na comparação dos resultados 37,76 . Outro fator benéfico reside na facilidade de inserção dos cimentos no tubo e o controle sobre eventual extravasamento, dissolução ou fragmentação, muito embora o extravasamento ou a sub-obturação, segundo DEEMER ${ }^{27}$ e WENGER ${ }^{110}$, por si só não comprometam a reparação do tecido intraósseo de ratos.

Apesar de desconhecermos a influência da sutura muscular na loja óssea, realizamos a mesma com fio tipo categute cromado monofilamentar devido ao mesmo ser reabsorvido rapidamente e apresentar baixo custo e rápido 111 . Entretanto, o fio de nylon também poderia ter sido utilizado, pois apesar de permanecer indefinidamente nos tecidos, integrar-se-ia prontamente aos mesmos através do encapsulamento fibroso ${ }^{111}$.

Como medida extra de segurança e para o conforto dos animais, depois de operados, estes receberam antimicrobianos e antiinflamatórios injetáveis, a cada 24 horas, durante 5 dias (Fig. 11).

O desalojamento do tubo quando inserido no tecido subcutâneo de ratos é considerado uma limitação do método, porque o contato do cimento com o tecido não permanece no mesmo local durante o intervalo de estudo ${ }^{69}$. Segundo GUIDUGLI NETO ${ }^{41}$ e $\mathrm{OLSSON}^{76}$, a restrição do espaço e proteção da cortical óssea descritas para o estudo em tíbias, não impossibilita o desalojamento do tubo, contudo a movimentação dos implantes intra-ósseos parece ser menos provável do que aquela observada nos implantes subcutâneos 105,36,72,65 
A movimentação dos animais nos períodos iniciais, provavelmente devido à menor sensibilidade dolorosa pós-operatória obtida em função dos medicamentos aplicados, talvez tenha colaborado para que as fraturas ocorressem.

Durante a remoção dos tubos, depois de fixados e desmineralizados os espécimes, verificamos que em parte destes o longo eixo dos implantes não coincidia com o do osso, consideração esta já descrita por FRIEND e BROWNE ${ }^{37}$ e TORABINEJAD et al ${ }^{103}$. Ainda, que os prejuízos para a obtenção dos cortes microscópicos fossem pequenos, desconhecemos o instante e o motivo por tal ocorrência.

Interessante relatar que, ao exame macroscópico dos tubos removidos, independente do tipo de cimento presente, algumas extremidades revelavam ausência do cimento nas extremidades. Desconhecemos até que ponto esta perda possa ser devida ̀̀ reabsorção do material por células inflamatórias ou decorrente de degradação pela ação das soluções de processamento histotécnico.

Baseando-se no fato do reparo ósseo humano de alvéolos concretizar-se após 60 dias em média ${ }^{87}$ e, definindo compatibilidade tecidual de uma material como sendo a capacidade de não intervir na qualidade e tempo do reparo, o período de 90 dias pós-implante para a coleta dos resultados, parece ser suficiente para se observar os resultados. Se projetássemos um paralelo entre os períodos de vida dos ratos e homens, o prazo referente à ultima coleta deste experimento corresponderia à 3,6 anos na espécie humana.

Os estudos intra-ósseos permitem que os cimentos sejam avaliados em prazos médios ou longos ${ }^{92}$. As vantagens de períodos observacionais longos recaem sobre a maior quantidade de informações ${ }^{85}$ e detecção de possivveis alterações químicas ou físicas dos 
cimentos, como desintegração ou reabsorção, menos evidentes em prazos menores.

A primeira coleta dos espécimes ocorreu aos 30 dias da implantação dos tubos porque desejávamos observar a reação tecidual exclusiva dos materiais em teste, sem a interferência de eventuais fenômenos inflamatórios relativos ao ato cirúrgico, os quais tendem a cessar aproximadamente no $14^{\circ} \mathrm{dia}^{82,45,109}$.

De acordo com GUIDUGLI NETO ${ }^{41}$, somente após 69 dias o defeito ósseo executado na tíbia dos ratos havia sido completamente substituído por osso do tipo compacto. Optamos pelo período final de 90 dias, embasados nas recomendações da FDl ${ }^{91}$, para descobrir se a pasta LSR mantinha o padrão de remissão da inflamação, após 60 dias atribuído a outros cimentos a base de óxido de zinco e eugenol $^{60,76,75,72,83}$. Pode-se ressaltar ainda que a pequena superfície de cimento em contato com os tecidos torna mais lenta a liberação de possiveis irritantes químicos ${ }^{36,51}$, sendo isso talvez uma justificativa a mais para a coleta ser feita aos 90 dias.

Em nosso estudo, optamos por utilizar o fêmur e a tíbia do membro inferior direito, ao invés das duas tíbias como os experimentos de WENGER et al ${ }^{110}$,DEEMER e TSAKNIS ${ }^{27}$,AUSTIN et al ${ }^{3}$,OLSEN ${ }^{75}$, para que o animal pudesse se locomover com os demais membros, durante o período de recuperação. Alguns autores sugerem o emprego somente da tíbia41,109, no entanto, optamos pelo uso da tíbia e do fêmur em virtude da inviabilidade, tanto do número exagerado de animais necessário, quanto ao número reduzido de amostras por grupo.

Conservmos as duas extremidades dos tubos abertas, conforme outros estudos $36,37,60,27,110,3,75,102$, embora TORNECK ${ }^{105}$ advogue a obliteração de uma ponta. Concordamos e dividimos as 
afirmações de MORAIS ${ }^{71}$ de que ao se utilizar duas extremidades, obtêm-se duas áreas para avaliação, reduzindo possíveis artefatos de técnica que, porventura possam ocorrer, durante o processamento histotécnico.

Para esta pesquisa, a quantidade de seis amostras por grupo experimental, embora pequena, atingia o número mínimo determinado à pesquisa com animais segundo a norma ADA 198299. Essa amostragem se aproxima e vem ao encontro daquela utilizada por diversos autores ${ }^{74,68,5,101,26,93,76,3,72,90}$.

A adoção de um grupo controle em nosso estudo, provido por tubos vazios, objetivou verificar a reação tecidual produzida restrita ao material de confecção do tubo e, a partir desta, definir o potencial irritativo ou osteogênico exclusivo dos materiais experimentais. Prática similar foi adotada em alguns estudos de compatibilidade tecidual óssea1 10,27,76,81,75 e subcutânea 105,36,71.

○ uso de escores, embora não tão preciso quanto a contagem celular, conformou-se com achados em outras pesquisas $^{81,5,75,83,72}$ e corroboram para a segurança dos resultados.

OLSSON ${ }^{76}$ defende que a quantificação das respostas teciduais pelo método de escores é possível somente quando materiais de irritabilidade diferentes são testados. Como a medida de detalhes no método subjetivo quantitativo depende da precisão e do conhecimento humano, diferenças sutis entre os fenômenos estudados são mais difíceis de serem detectadas do que o método numérico.

Este fato, associado ao número maior de amostras exigido pelos testes não-paramétricos ${ }^{16}$, para se detectar uma diferença real entre duas populações, podem explicar o número de diferenças estatísticas significantes, presentes neste e também em outros estudos ${ }^{10,3}$. 
Dessa forma utilizamos medianas, obtidas a partir da análise de variância, para confeccionar gráficos comparativos e facilitar as comparações entre os grupos (Figs. 31,33 e 34).

Estabelecemos a categorização e escolha dos aspectos microscópicos a serem analisados com base nos comportamentos histológico e inflamatório, característicos do tecido ósseo de nosso experimento, aos empregados por DEEMER e TSAKNIS ${ }^{27}, \mathrm{OLSSON}^{76}$, PERTOT $^{81}$, BHAMBHANI, OLSEN $^{75}$; TORABINEJAD ${ }^{103}$, TORABINEJAD ${ }^{103}$, MORETTON ${ }^{72}$, PISSIOTIS ${ }^{83}$.

Optamos por avaliação qualitativa descritiva cega, realizada por um examinador calibrado, onde atribuiram-se valores ordinais aos fenômenos de acordo com uma escala numérica predeterminada.

Não achamos pertinente mensurar a espessura da cápsula fibrosa baseados nas afirmações de TORNECK ${ }^{105}$ quanto à confiabilidade destas respostas. Respeitamos o fato de outros pesquisadores o terem executado, contudo a ausência na literatura de relação proporcional entre toxicidade do material e a espessura da cápsula, bem como as dificuldades em padronizar os ângulos de corte das lâminas no micrótomo, poderiam resultar em resultados falsopositivos e negativos. 


\subsection{Dos resultados}

\subsubsection{Relativos aos Fenômenos Inflamatórios}

Durante análise geral dos dados, pudemos observar diferenças microscópicas inflamatórias mais significativas nos grupos à base de pasta zinco-enólica quando comparados ao grupo dotado de agregado de trióxido mineral e grupo controle.

Na literatura, a grande maioria dos estudos descreve redução e desaparecimento da inflamação com o passar do tempo em relação aos cimentos de óxido de zinco e eugenol 27,72,37,75,71,83,103,119.

No período de 30 dias, o infiltrado inflamatório crônico associado aos cimentos de base zinco-enólica, definido como variando entre leve e moderado, comparou-se aos relatados em outros estudos empregando cimentos compostos com o óxido de zinco e eugenol $75,72,83,103,5,27,110$. Poderíamos atribuir estes elevados índices iniciais, ̀̀ ação tóxica de algum dos componentes da fórmula da pasta $L S \otimes$ e aditivos por nós incorporados, ou à liberação inicial do eugenol não reagido, considerado tóxico às células ${ }^{50,51,36,37}$, quando da inserção dos cimentos recém-misturados na intimidade dos tecido $27,76,50,51,81,5,75,83$.

De acordo com HUME ${ }^{50}$, outro elemento a ser levado em conta é o tamanho da superfície de cimento em contato com os tecidos, pois quanto maior a área exposta, maior a liberação inicial de eugenol, e conseqüente maior a irritação.

Estas afirmações de alguma forma, seriam importantes do ponto de vista clínico e nos sugerem que, quanto menor a extensão da cavidade retrógrada, menor o efeito inflamatório do cimento. 
A queda inflamatória acentuada que se observou no intervalo entre 30 e 60 dias, associado ao emprego do óxido de zinco e eugenol, corrobora com os relatos de outros autores $27,72,110,37,75,71,83$. Esta redução pode ser verificada através da figura 31, onde pode ser notado também um decréscimo menos proeminente destes fenômenos no período de 60 a 90 dias $^{37,81}$.

A redução dos níveis de liberação de eugenol com o transcorrer do tempo $69,51,75$, associada à troca dos fluídos teciduais talvez expliquem a queda progressiva dos níveis inflamatórios observada em nosso estudo nos cimentos providos desta substância.

Todavia, nossos resultados destoam daqueles encontrados por FRIEND e BROWNE ${ }^{36}$ e BHAMBHANI \& BOLANOS ${ }^{5}$, quando a inflamação persistiu após 12 e 15 meses de estudo com esta classe de cimentos.

As comparações (Tabelas 20 e 21) quanto ao infiltrado inflamatório, revelaram significância estatística $(\rho=0.05)$ relativa ao grupo 4, quando comparado ao grupo controle, aos 30 e 90 dias. Esta evidência sugere que o subnitrato de bismuto, quando associado ao hidróxido de cálcio, poderia ter um potencial irritante superior e mais prolongado do que aquele atribuído ao iodofórmio, pois a diferença significativa observada quando do acréscimo desta substância, aos 30 dias, mostrou-se estatisticamente insignificante aos 60 e 90 dias.

A adição do hidróxido de cálcio aos materiais à base de óxido de zinco e eugenol ocasionou um sutil acréscimo dos fenômenos característicos da inflamação crônica, principalmente aos trinta dias, em relação aos cimentos onde aquela substância não aparecia (Figs. 31 à 34). 
Nos períodos subseqüentes, a inflamação decresceu na mesma proporção que os grupos desprovidos de hidróxido de cálcio, contudo a leve superioridade dos índices ainda pôde ser detectada.

O elevado pH do hidróxido de cálcio ou uma possível interação química com outra substância ${ }^{94}$, talvez pudessem justificar estes achados. Dessa forma, a medida do potencial hidrogeniônico das pastas acrescidas desta substância torna-se fundamental para ajudar a esclarecer a possivel causa do comportamento inflamatório observado. Entretanto, estas suposições vão de encontro aos achados de FUJISAWA et al ${ }^{38}$, que, pesquisando em cultura de células, não constataram aumento da toxicidade do hidróxido de cálcio pela adição de eugenol.

Neste estudo, tanto o trióxido mineral quanto o grupo controle mantiveram índices de infiltrado inflamatório inferiores aos demais grupos e constantes ao longo dos três períodos experimentais, embora do ponto de vista estatístico, somente os índices de inflamação do grupo controle tenham sido estatisticamente diferentes dos grupos com óxido de zinco e eugenol (Tabelas 20 e 21).

Nossos achados não concordam com os de MORETTON et al $^{72}$ que descrevem níveis superiores de inflamação ao MTA quando comparado ao SuperEBA e, com os de MORAIS ${ }^{71}$ quando confrontado com a pasta Lysandå, aos 30 e 60 dias.

A presença de linfócitos e plasmócitos nos estudos de biocompatibilidade elevam a possibilidade de que respostas imunes antígeno-específicas sejam induzidas por materiais endodônticos obturadores ou por componentes desses materiais ${ }^{93}$.

Durante nossa análise, linfócitos e plasmócitos foram vistos em pequena quantidade, principalmente nos períodos de 30 e 60 dias, relacionados em maior grau ao hidróxido de cálcio e subnitrato de 
bismuto (Anexo G). A hipótese de um alto grau de impureza associado ao subnitrato de bismuto pode ser formulada, conquanto o hidróxido de cálcio utilizado também poderia responder por estes achados.

Os macrófagos podem reunir-se, constituindo as células gigantes multinucleadas, caso o material a ser fagocitado seja maior do que o citoplasma de um único macrófago ${ }^{107}$.

A presença de células gigantes associadas aos cimentos de óxido de zinco e eugenol, de diferentes formulações, é bastante mencionada na literatura $36,61,27,76,102,84,72,90$.

A diminuição do número de células gigantes multinucleadas, associadas aos grupos 1 a 4, com o transcorrer dos períodos, seguiu o padrão de remissão já descrito ao infiltrado inflamatório crônico. Ainda, o desaparecimento deste tipo de células, nos grupos à base de óxido de zinco e eugenol, ocorreu somente nos grupos com acréscimo de iodofórmio, e no prazo de noventa dias (Fig. 32). Interessante notar que, quando o subnitrato de bismuto e o hidróxido de cálcio apareciam associados, a quantidade de células gigantes mostrava-se consideravelmente superior à dos demais grupos, e não diminuindo a partir dos 60 dias. Como se não bastasse, das 7 amostras onde células gigantes multinucleadas do tipo Langhans apareciam, 6 estavam relacionadas com presença de subnitrato de bismuto acrescido ou não do hidróxido de cálcio (Fig. 16.2). Á este tipo específico de célula, é associado um componente imunogênico ${ }^{22}$.

Apesar de restritas aos períodos de 30 e 60 dias e em pequena quantidade, as células gigantes multinucleadas também apareciam, neste experimento, adjacentes ao trióxido mineral agregado (Fig. 32), conforme descrito em outros estudos $43,68,82,10$.

Ao nosso ver, considerar o iodofórmio, subnitrato de bismuto ou hidróxido de cálcio como estimuladores do aparecimento 
de células gigantes, verificadas em nosso estudo, é um tanto imprudente uma vez que outros componentes do cimento poderiam ser responsáveis por este achado.

A degradação de parte do material, em contato com a circulação dos fluidos teciduais ${ }^{36,37}$, ou a própria dispersão das partículas de pó dos aditivos não incorporadas ao cimentos experimentais, conforme descrito por BHAMBHANI \& BOLANOS ${ }^{5}$ e ZUOLO ${ }^{117}$ com outros cimentos, poderiam também explicar a presença das células gigantes multinucleadas,.

Pudemos observar, aos 30 dias, 16 casos de necrose de coagulação, enquanto aos 60 dias este número caiu para nove, e aos 90 dias não mais foram observados (Fig. 34).

A necrose do tipo coagulação, presente neste experimento é provavelmente resultante da agressão química de algum composto dos materiais. A redução dos graus de necrose conforme a evolução dos períodos experimentais, talvez possa ser explicada pela regressão dos niveis de eugenol liberados $^{51}$ e perda de toxicidade das substâncias.

Ao iodofórmio são atribuidas propriedades irritantes que produzem necrose tecidual, atraindo células de defesa para a região, principalmente leucócitos polimorfonucleares e macrófagos, comportamento que, sob alguns aspectos, favorece o reparo 32,33,25.

Todavia, nesta pesquisa, além do iodofórmio, outros componentes dos demais grupos parecem também ser responsáveis pela formação das áreas de necrose. Concorre para isto, o comportamento inflamatório parecido observado nos grupos onde o subnitrato de bismuto havia sido incluido como agente radiopacificador, verificados nos períodos de 30 e 60 dias /Figs. 14.2, 15.1 e 34). HOLLAND ${ }^{46}$, inclusive, observou que adicionar iodofórmio 


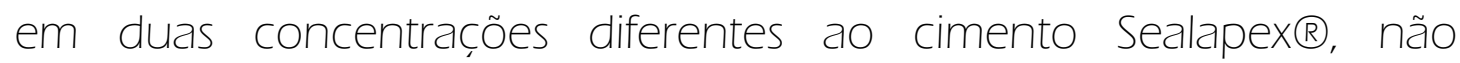
produzia alterações inflamatórias significativas.

No que se refere a organização do tecido de granulação, na forma de delineamento e justaposição dos feixes de fibras colágenas, o modelo de organização progressiva, verificado em nosso estudo, segue a mesma seqüência de redução apresentada pelo infiltrado inflamatório e necrose tecidual, com declínio progressivo mais acentuado no período entre 30 e 60 dias (Fig. 33). A maturação do tecido continua e, ao fim deste período, a organização das fibras colágenas com os grupos onde o óxido de zinco e eugenol estava presente aproximava-se daquela relatada ao trióxido mineral agregado, evidente desde o primeiro período de observação.

No intervalo compreendido entre 60 e 90 dias, 0 modelamento e a condensação das fibras colágenas nos grupos dotados de pasta zinco-enólica, superava àquela observada com o agregado de trióxido mineral.

Este modelo de reparo concorda com aqueles verificados em outros experimentos utilizando óxido de zinco e eugenol ${ }^{72,82,85}$ e agregado de trióxido mineral ${ }^{103,103,72}$.

Digno de nota é a evolução pela qual o tecido de granulação dos grupos acrescidos de iodofórmio atravessaram, partindo de uma organização frouxa aos 30 dias, estatisticamente diferente do grupo controle (Tabela 20), até atingir uma formação capsular organizada e densa ao fim do experimento. (Figs. 29.2 e 30.2).

As observações de MOLNAR ${ }^{69}$ vem ao encontro das nossas, pois ao testar o óxido de zinco e eugenol com iodofórmio (40,6\%) e hidróxido de cálcio (1,07\%), este autor constatou que a desorganização inicial aos 30 dias foi substituída por uma cápsula de fibras bem condensadas no período de 90 dias. 
Não encontramos na literatura, dados correlacionados especificamente aos efeitos do subnitrato de bismuto na organização do tecido de granulação e, embora houvesse amadurecimento do tecido, a sua concretização não foi tão evidente quanto aquela atribuida à mistura com o iodofórmio (Figs. 27.2, 28.2, 29.2, 30.2 e 33).

Nos grupo controle, os tubos vazios abertos em ambas extremidades já apresentavam aos 30 dias, em seu espaço interno, um tecido de granulação maduro invaginado (Figs.12.1 e 12.2). A análise estatística não revelou diferenças significantes quanto à organização tecidual, aos 60 e 90 dias, entre o grupo controle e os grupos experimentais (Anexos $\bigcirc$ e P)

RAMALHO, SANTANA e RAMALHO ${ }^{85}$ demonstraram que a redução do eugenol na mistura proporciona condensação mais precoce das fibras colágenas.

Analisando-se a evolução dos cimentos de óxido de zinco e eugenol, a adição de compostos às respectivas formulações com o intuito de reforçá-los, mostrou melhoras em suas propriedades biológicas ${ }^{37,67,38,21}$, muito embora HUME ${ }^{50}$ creia que estas mudanças ocorram exclusivamente em função das variações nas proporções de óxido de zinco e eugenol dos cimentos.

A pasta de impressão LSR tipo II possui aditivos diferentes em sua fórmula e quantidade reduzida de eugenol (10,25\% na pasta catalisadora) quando comparada a outros cimentos retrobturadores, também a base de óxido de zinco e eugenol.

A formação e organização gradual de fibras colágenas e a redução na quantidade de células inflamatórias são evidências da evolução do processo de reparo, contudo a permanência de tecido fibrótico em contato com a pasta zinco-enólica e aditivos, poderia significar um atraso no decurso da regeneração ou uma reparação por 
fibrose. $\bigcirc$ MTA, diferentemente da pata zinco-enólica, mostrava um tecido de granulação delgado e pouco celularizado, evidenciando uma fase mais adiantada do processo de reparo (Figs. 13.1, 20.1 e 26.1).

A reparação por fibrose pode ser analisada como uma das etapas do processo osteogênico ${ }^{103}$ ou como uma resposta do corpo humano a um irritante de toxicidade baixa e contínua ${ }^{81}$. Todavia, apesar deste tipo de reparo não poder ser diferenciado nos aspectos clínico e radiográfico, a sua capacidade eventual de recuperação necessitaria de recursos adicionais ${ }^{22}$.

\subsubsection{Relativos à Neoformação Óssea}

p papel do hidróxido de cálcio, quando incorporado na composição de cimentos endodônticos, é bem estabelecido como indutor da deposição de tecido mineralizado ${ }^{74,6,46,35,48,90}$

A capacidade deste tipo de cimento em liberar íons cálcio é extremamente importante para uma excelente performance nos tecidos periapicais ${ }^{28}$.

A não constatação de melhora das propriedades biológicas, quando da adição do hidróxido de cálcio aos cimentos de óxido de zinco e eugenol, verificada neste experimento, poderia estar relacionada à ausência de concentrações terapêuticas adequadas daquela substâncial , à insolubilidade do cimento ${ }^{28}$, ou à ocorrência de reação química entre o eugenol e o hidróxido de cálcio, como sugere TAGGER ${ }^{4}$, ao afirmar que os íons cálcio desprendidos do material reagiriam imediatamente com o eugenol livre do cimento, formando o sal eugenolato de cálcio, fato também subsidiado por HOLLAND et 
al ${ }^{48}$, que, pesquisando em subcutâneo de ratos, não constataram a formação de carbonato de cálcio associado ao cimento CRCS.

BERBERT ${ }^{6}$, ao adicionar hidróxido de cálcio no cimento AH26, verificou a formação de barreira apical de tecido duro, separada do material obturador por delgada camada de fibras colágenas, ao passo que nesta pesquisa, de um modo geral, observamos a interposição de tecido fibroso entre o cimento e as trabéculas osteóides, a partir dos 60 dias, quando avaliados os grupos 3 e 4. (Figs. $22.2,24.2,28.2$ e 30.21

Inúmeras pesquisas demontram as qualidades osteogênicas do trióxido mineral agregado, como verdadeiro estimulador da deposição de tecido mineralizado 103,103,87,47,72,48,30,56 e, tais características assemelham-se de alguma forma ás do hidróxido de cálcio. Baseados nestas observações, HOLLAND et al ${ }^{47}$ afirmam que o mecanismo de ação do hidróxido de cálcio e trióxido mineral agregado, para a deposição de tecido duro, podem ser idênticos.

As trabéculas ósseas evidenciadas em nosso estudo, circunvizinhas ao MTA, fortalecem a definição de TORABINEJAD ${ }^{103}$ de que o mesmo não interfere com o decurso do reparo (Figs. 13.2, $20.2 \mathrm{e}$ 26.11.

A constatação de trabéculas osteóides nos arredores e interior dos tubos vazios, já no período de 30 dias (Figs. 12.1 e 12.2), demonstra a presença de intensa atividade osteoblástica.

Em nosso experimento, não observamos qualquer indício de trabéculas ósseas nas proximidades dos cimentos á base de óxido de zinco e eugenol (Fig. 35); todavia, a formação de barreira osteóide à distância já pode ser observada a partir dos 60 dias (Fig. 936).

Todavia, os resultados acima descritos divergem daqueles encontrados por OLSEN ${ }^{75}$ que verificou o aparecimento de trabéculas 
ósseas justapostas ao IRM aos 56 dias, dos achados de MORETTON ${ }^{72}$, que verificaram esta mesma condição, junto ao EBA, a partir dos 15 dias.

A neoformação óssea limitada do contato com o trióxido mineral agregado por delgada camada de fibras colágenas maduras, talvez seja um indício da compatibilidade tecidual deste material, potencialmente em decorrência do seu baixo grau de toxicidade, permitindo a osteogênese como seqüência natural do desaparecimento dos fenômenos inflamatórios ${ }^{103,53,22}$.

Provavelmente a inexistência de material de preenchimento aliada aos cuidados com a antissepsia, a abertura bilateral do tubo e a presença exclusiva de coágulo sejam responsáveis pela formação de uma barreira óssea nas adjacências do grupo controle (Figs. 19.1, 19.2, 25.1 e 25.2).

Não menos importante seria considerar a possibilidade de que, caso houvessem períodos superiores a 90 dias, barreiras mais completas formar-se-iam.

Inúmeras são as divergências quanto à definição do reparo tecidual ideal. A circunscrição de um corpo estranho por tecido fibroso livre de infiltrado inflamatório, por si só, como verificamos com o cimento à base de pasta zinco-enólica aos 90 dias, indicaria a boa tolerância tecidual ao material 105,110,27,3,81,75,72,83,117. Da mesma forma, o reparo periradicular como regeneração dos tecidos periapicais, definidos por ligamento periodontal, cemento e osso alveolar em condições de normalidade, deveriam ser características de toda conduta clínica e, de acordo com nossa pesquisa, o MTA $₫$ preencheria esta condição, porém existem evidências positivas de que os cimentos de base zinco-enólica correspondam à essa expectativa. 
Do ponto de vista clínico, independente do material de escolha, os argumentos acima descritos seriam plenamente aceitáveis, caracterizando um reparo tecidual não absoluto, mas com todos os sinais de normalidade.

Dessa forma, as discussões, nos campos histológico e clínico-cirúrgico, quanto às propriedades biológicas dos cimentos retrobturadores, permanecem e constituem um campo fértil para que novas pesquisas sejam realizadas. 
CONSIDERAÇÕES FINAIS 


\section{CONSIDERAÇÕES FINAIS}

Concebemos este trabalho com o propósito de testar microscopicamente, em tecido ósseo, os efeitos de substâncias que supostamente melhorariam o comportamento nos tecidos da pasta zinco-enólica, cujos testes "in vitro" e "in vivo" outrora realizados, evidenciaram seu potencial como material retroburador.

No mesmo estudo, pretendemos investigar as propriedades biológicas do trióxido mineral agregado ao ser implantado em um sítio potencialmente osteogênico, e concomitantemente, comparará-las ao comportamento tecidual que os cimentos experimentais à base de óxido de zinco eugenol pudessem apresentar.

Embora tenhamos observado a formação de reparo por fibrose com o cimento experimental, diferente daquele observado com o MTA®, estes resultados não são definitivos, e sim mais um degrau na busca por um cimento de fácil disponibilidade e baixo custo.

método utilizado neste estudo não reproduz os efeitos dos movimentos dentais e da presença de bactérias no periápice, causa principal da perpetuação dos insucessos endodônticos.

Assinalamos assim, a necessidade de mais pesquisas "in vitro" ou "in vivo" estudando a influência da contaminação bacteriana ou a substituição de componentes da fórmula, para acrescentar qualidades que levem ao desenvolvimento do material retrobturador ideal. 
CONCLUSÕES 


\section{CONCLUSÕES}

Dentro das possibilidades deste método, os resultados obtidos nos permitem chegar às seguintes deduções:

- $\bigcirc$ agregado de trióxido mineral mostrou excelente compatibilidade tecidual.

- Embora existissem diferenças microscópicas, o reparo ao término do experimento apresentou-se estatisticamente semelhante quando do emprego de agregado trióxido mineral agregado ou pasta zincoenólica acrescida de aditivos.

- A adição de agentes radiopacificadores aos materiais não resultou em diferenças estatísticas significantes.

- $\bigcirc$ acréscimo de hidróxido de cálcio à pasta zinco-enólica não melhorou suas propriedades biológicas. 
ANEXOS 


\section{ANEXOS}

ANEXO A - Análise microscópica - Escores atribuídos aos diferentes grupos no período de 30 dias.

\begin{tabular}{|c|c|c|c|c|c|c|c|c|}
\hline Grupo & Período & Identific. & Infiltr.Inflam. & Necrose & $\begin{array}{l}\text { Celulas } \\
\text { Gigantes, }\end{array}$ & $\begin{array}{c}\text { Tecido } \\
\text { Fibroso }\end{array}$ & $\begin{array}{l}\text { Trabéculas } \\
\text { Interface }\end{array}$ & $\begin{array}{c}\text { Barreira } \\
\text { Óssea }\end{array}$ \\
\hline Grupo 2 & $30 d$ & 1.T & 1.6 & 0 & 1 & 1.6 & 3 & 2 \\
\hline Grupo 2 & $30 d$ & 4.T & 1.3 & 1 & 1 & 1.5 & 3 & 4 \\
\hline Grupo 2 & $30 d$ & $15 . \mathrm{F}$ & 1.5 & 1 & 0 & 1.3 & 3 & 2 \\
\hline Grupo 2 & $30 d$ & $44 . \mathrm{F}$ & 1.3 & 1 & 0 & 1.1 & 3 & 3 \\
\hline Grupo 1 & $30 d$ & 12. $\mathrm{T}$ & 1.8 & 1 & 1 & 1.8 & 3 & 2 \\
\hline Grupo 1 & $30 d$ & 16.T & 1.7 & 1 & 1 & 1.6 & 3 & 3 \\
\hline Grupo 1 & $30 d$ & $32 . F$ & 1.5 & 1 & 0 & 1.6 & 3 & 4 \\
\hline Grupo 1 & $30 d$ & 47.F & 1.3 & 0 & 1 & 1 & 3 & 2 \\
\hline Grupo 4 & $30 d$ & $1 . \mathrm{F}$ & 1.6 & 0 & 1 & 1.3 & 3 & 2 \\
\hline Grupo 4 & $30 d$ & $20 . T$ & 1.9 & 1 & 1 & 1.7 & 3 & 2 \\
\hline Grupo 4 & $30 d$ & $20 . \mathrm{F}$ & 1.6 & 1 & 1 & 1.2 & 3 & 3 \\
\hline Grupo 4 & $30 d$ & 22.T & 1.6 & 1 & 1 & 1.3 & 3 & 2 \\
\hline Grupo 4 & $30 d$ & $25 . T$ & 2 & 1 & 0 & 1.8 & 3 & 3 \\
\hline Grupo 4 & $30 d$ & $29 . F$ & 1.4 & 1 & 0 & 1.2 & 3 & 3 \\
\hline Grupo 3 & $30 d$ & $22 . F$ & 1.2 & 0 & 0 & 1 & 3 & 2 \\
\hline Grupo 3 & $30 d$ & 29.T & 2 & 1 & 1 & 2 & 3 & 4 \\
\hline Grupo 3 & $30 d$ & 32.T & 1.5 & 1 & 0 & 1.4 & 3 & 3 \\
\hline Grupo 3 & $30 d$ & $35 . T$ & 1.8 & 1 & 0 & 1.7 & 3 & 3 \\
\hline Grupo 3 & $30 d$ & $35 . F$ & 2 & 1 & 1 & 1.9 & 3 & 2 \\
\hline Grupo 3 & $30 d$ & $42 . F$ & 1.4 & 1 & 1 & 1.2 & 3 & 4 \\
\hline Grupo 5 & $30 d$ & $16 . \mathrm{F}$ & 1.3 & 0 & 1 & 1.3 & 3 & 3 \\
\hline Grupo 5 & $30 d$ & 37.T & 0.6 & 0 & 0 & 0.8 & 3 & 0 \\
\hline Grupo 5 & $30 d$ & 37.F & 0.7 & 0 & 0 & 0.9 & 0 & 0 \\
\hline Grupo 5 & $30 d$ & $44 . T$ & 0.6 & 0 & 0 & 0.8 & 1 & 0 \\
\hline Grupo 5 & $30 d$ & $50 . \mathrm{F}$ & 0.4 & 0 & 0 & 0.5 & 0.5 & 0 \\
\hline Controle & $30 d$ & 4.F & 0.3 & 0 & 0 & 0.5 & 0.5 & 0 \\
\hline Controle & $30 d$ & $25 . F$ & 0.6 & 0 & 0 & 0.8 & 0 & 1 \\
\hline Controle & $30 d$ & 47.T & 0.3 & 0 & 1 & 0.4 & 0 & 0 \\
\hline Controle & $30 d$ & $50 . T$ & 0.3 & 0 & 0 & 0.4 & 0 & 1 \\
\hline
\end{tabular}


ANEXO B - Análise microscópica - Escores atribuídos aos diferentes grupos no período de 60 dias.

\begin{tabular}{|c|c|c|c|c|c|c|c|c|}
\hline Grupo & Período & Identific. & Infiltr.Inflam. & Necrose & $\begin{array}{l}\text { Celulas } \\
\text { Gigantes, }\end{array}$ & $\begin{array}{l}\text { Tecido } \\
\text { Fibroso }\end{array}$ & $\begin{array}{l}\text { Trabéculas } \\
\text { Interface }\end{array}$ & $\begin{array}{c}\text { Barreira } \\
\text { Óssea }\end{array}$ \\
\hline Grupo 2 & $60 d$ & $2 . T$ & 0.9 & 0 & 1 & 1.1 & 3 & 0 \\
\hline Grupo 2 & $60 d$ & 6.T & 0.8 & 1 & 0 & 0.9 & 3 & 3 \\
\hline Grupo 2 & $60 d$ & $8 . F$ & 0.7 & 1 & 1 & 0.6 & 3 & 0 \\
\hline Grupo 2 & $60 d$ & $14 . \mathrm{F}$ & 1.4 & 0 & 0 & 1.5 & 3 & 2 \\
\hline Grupo 2 & $60 d$ & $43 . \mathrm{F}$ & 0.6 & 0 & 0 & 0.8 & 3 & 1 \\
\hline Grupo 1 & $60 d$ & 11.T & 0.7 & 0 & 0 & 0.8 & 3 & 1 \\
\hline Grupo 1 & $60 d$ & $11 . \mathrm{F}$ & 0.4 & 0 & 0 & 0.6 & 3 & 0 \\
\hline Grupo 1 & $60 d$ & 14. $\mathrm{T}$ & 0.4 & 0 & 0 & 0.5 & 3 & 3 \\
\hline Grupo 1 & $60 d$ & $18 . T$ & 1.7 & 1 & 1 & 1.6 & 3 & 3 \\
\hline Grupo 1 & $60 d$ & 33.F & 1.4 & 0 & 1 & 1.3 & 3 & 0 \\
\hline Grupo 1 & $60 d$ & $48 . F$ & 0.7 & 1 & 0 & 0.9 & 3 & 3 \\
\hline Grupo 4 & $60 d$ & $21 . T$ & 1.6 & 1 & 1 & 1.5 & 2 & 1 \\
\hline Grupo 4 & $60 d$ & $21 . F$ & 1 & 1 & 1 & 1 & 3 & 1 \\
\hline Grupo 4 & $60 d$ & 23.T & 0.5 & 0 & 0 & 0.7 & 3 & 3 \\
\hline Grupo 4 & $60 d$ & $2 . \mathrm{F}$ & 0.9 & 0 & 0 & 1 & 3 & 3 \\
\hline Grupo 4 & $60 d$ & 27. $T$ & 0.7 & 1 & 0 & 0.7 & 3 & 1 \\
\hline Grupo 4 & $60 d$ & $30 . F$ & 0.4 & 0 & 0 & 0.6 & 3 & 2 \\
\hline Grupo 3 & $60 d$ & $23 . F$ & 0.7 & 1 & 1 & 0.9 & 3 & 1 \\
\hline Grupo 3 & $60 d$ & $30 . T$ & 1.2 & 0 & 0 & 1.1 & 3 & 0 \\
\hline Grupo 3 & $60 d$ & 33.T & 1.1 & 0 & 0 & 1 & 3 & 4 \\
\hline Grupo 3 & $60 d$ & 34.T & 1.2 & 0 & 1 & 1.6 & 3 & 2 \\
\hline Grupo 3 & $60 d$ & $34 . F$ & 0.6 & 0 & 0 & 0.8 & 3 & 4 \\
\hline Grupo 3 & $60 d$ & 41.F & 0.4 & 1 & 0 & 0.6 & 3 & 3 \\
\hline Grupo 5 & $60 d$ & $18 . \mathrm{F}$ & 0.4 & 0 & 0 & 0.6 & 2 & 0 \\
\hline Grupo 5 & $60 d$ & $38 . F$ & 0.8 & 0 & 0 & 1 & 3 & 0 \\
\hline Grupo 5 & $60 d$ & 41. $\mathrm{T}$ & 0.4 & 0 & 0 & 0.8 & 1 & 4 \\
\hline Grupo 5 & $60 d$ & 43. $\mathrm{T}$ & 0.9 & 0 & 1 & 1.1 & 3 & 0 \\
\hline Grupo 5 & $60 d$ & $51 . F$ & 0.4 & 0 & 0 & 0.7 & 0 & 0 \\
\hline Controle & $60 d$ & $6 . \mathrm{F}$ & 0.2 & 0 & 0 & 0.3 & 0 & 1 \\
\hline Controle & $60 d$ & $27 . F$ & 0.5 & 0 & 0 & 0.7 & 3 & 3 \\
\hline Controle & $60 d$ & 48. $T$ & 0.3 & 0 & 0 & 0.5 & 0 & 0 \\
\hline Controle & $60 d$ & 51.T & 0.3 & 0 & 0 & 0.4 & 3 & 0 \\
\hline
\end{tabular}


ANEXO C - Análise microscópica - Escores atribuídos aos diferentes grupos no período de 90 dias.

\begin{tabular}{|c|c|c|c|c|c|c|c|c|}
\hline Grupo & Período & Identific. & Infiltr.Inflam. & Necrose & $\begin{array}{l}\text { Celulas } \\
\text { Gigantes, }\end{array}$ & $\begin{array}{l}\text { Tecido } \\
\text { Fibroso }\end{array}$ & $\begin{array}{l}\text { Trabéculas } \\
\text { Interface }\end{array}$ & $\begin{array}{c}\text { Barreira } \\
\text { Óssea }\end{array}$ \\
\hline Grupo 2 & $90 \mathrm{~d}$ & $5 . T$ & 0.6 & 0 & 0 & 0.7 & 3 & 0 \\
\hline Grupo 2 & $90 d$ & $9 . T$ & 0.8 & 0 & 0 & 0.7 & 3 & 4 \\
\hline Grupo 2 & $90 d$ & $9 . \mathrm{F}$ & 0.6 & 0 & 1 & 1 & 3 & 0 \\
\hline Grupo 2 & $90 d$ & $13 . \mathrm{F}$ & 1 & 0 & 0 & 1.2 & 3 & 0 \\
\hline Grupo 2 & $90 d$ & $45 . \mathrm{F}$ & 0.8 & 0 & 0 & 0.6 & 3 & 0 \\
\hline Grupo 1 & $90 d$ & $10 . \mathrm{F}$ & 0.7 & 0 & 0 & 0.6 & 3 & 1 \\
\hline Grupo 1 & $90 d$ & $13 . T$ & 0.4 & 0 & 0 & 0.3 & 3 & 0 \\
\hline Grupo 1 & $90 \mathrm{~d}$ & 17.T & 0.8 & 0 & 0 & 0.9 & 3 & 3 \\
\hline Grupo 1 & $90 d$ & 31.F & 1.2 & 0 & 0 & 1.3 & 3 & 0 \\
\hline Grupo 1 & $90 d$ & $46 . \mathrm{F}$ & 0.3 & 0 & 0 & 0.3 & 3 & 2 \\
\hline Grupo 4 & $90 d$ & $3 . \mathrm{F}$ & 1.1 & 0 & 1 & 1 & 3 & 0 \\
\hline Grupo 4 & $90 d$ & 19.T & 1.2 & 0 & 1 & 1.1 & 3 & 1 \\
\hline Grupo 4 & $90 d$ & 19.F & 0.5 & 0 & 0 & 0.5 & 3 & 0 \\
\hline Grupo 4 & $90 d$ & $24 . T$ & 0.8 & 0 & 0 & 0.6 & 3 & 1 \\
\hline Grupo 4 & $90 d$ & 26.T & 0.6 & 0 & 0 & 0.8 & 3 & 4 \\
\hline Grupo 4 & $90 d$ & $28 . \mathrm{F}$ & 0.4 & 0 & 0 & 0.8 & 3 & 4 \\
\hline Grupo 3 & $90 d$ & $24 . F$ & 0.8 & 0 & 1 & 0.9 & 3 & 2 \\
\hline Grupo 3 & $90 d$ & $28 . T$ & 1.1 & 0 & 0 & 0.7 & 3 & 0 \\
\hline Grupo 3 & $90 d$ & 31. $T$ & 0.5 & 0 & 0 & 0.8 & 3 & 3 \\
\hline Grupo 3 & $90 d$ & 36.T & 0.3 & 0 & 0 & 0.2 & 3 & 4 \\
\hline Grupo 3 & $90 d$ & $36 . F$ & 0.4 & 0 & 0 & 0.7 & 3 & 4 \\
\hline Grupo 3 & $90 d$ & $40 . \mathrm{F}$ & 0.5 & 0 & 0 & 0.8 & 3 & 1 \\
\hline Grupo 5 & $90 d$ & $17 . \mathrm{F}$ & 0.5 & 0 & 0 & 1 & 3 & 0 \\
\hline Grupo 5 & $90 d$ & 39.T & 0.5 & 0 & 0 & 0.9 & 0 & 1 \\
\hline Grupo 5 & $90 d$ & $39 . F$ & 0.3 & 0 & 0 & 0.7 & 0 & 1 \\
\hline Grupo 5 & $90 d$ & $40 . T$ & 0.4 & 0 & 0 & 0.7 & 3 & 3 \\
\hline Grupo 5 & $90 d$ & $45 . T$ & 0.6 & 0 & 0 & 1.1 & 1 & 0 \\
\hline Grupo 5 & $90 \mathrm{~d}$ & 49.F & 0.4 & 0 & 0 & 0.6 & 3 & 0 \\
\hline Controle & $90 d$ & $5 . \mathrm{F}$ & 0.2 & 0 & 0 & 0.5 & 0 & 0 \\
\hline Controle & $90 d$ & $26 . F$ & 0.3 & 0 & 0 & 0.4 & 0 & 2 \\
\hline Controle & $90 d$ & $46 . T$ & 0.3 & 0 & 0 & 0.6 & 3 & 0 \\
\hline Controle & $90 d$ & $49 . T$ & 0.2 & 0 & 0 & 0.3 & 0 & 0 \\
\hline
\end{tabular}


ANEXO D - Medianas referentes à análise de variância dos grupos experimentais e controle aos 30 dias.

\begin{tabular}{|c|c|c|c|c|c|c|}
\hline & Controle & MTA & Grupo 2 & Grupo 4 & Grupo 1 & Grupo 3 \\
\hline $\begin{array}{l}\text { Infiltrado } \\
\text { Inflam. }\end{array}$ & 0.30000000 & 0.60000000 & 1.40000000 & 1.60000000 & 1.60000000 & 1.65000000 \\
\hline Necrose & 0.000 & 0.000 & 1.00000000 & 1.00000000 & 1.00000000 & 1.00000000 \\
\hline Cél. Gigantes & 0.00000000 & 0.00000000 & 0.50000000 & 1.00000000 & 1.00000000 & 0.50000000 \\
\hline $\begin{array}{l}\text { Aspecto Tec. } \\
\text { Granulação }\end{array}$ & 0.45000000 & 0.80000000 & 1.40000000 & 1.30000000 & 1.60000000 & 1.55000000 \\
\hline $\begin{array}{c}\text { Trabéc. Ósseas } \\
\text { na Interface }\end{array}$ & 0.25000000 & 1.00000000 & 3.00000000 & 3.00000000 & 3.00000000 & 3.00000000 \\
\hline Barreira Óssea & 0.50000000 & 0.00000000 & 1.50000000 & 2.00000000 & 1.00000000 & 3.00000000 \\
\hline
\end{tabular}

ANEXO E - Medianas referentes à análise de variância dos grupos experimentais e controle aos 60 dias.

\begin{tabular}{ccccccc} 
& Controle & MTA & Grupo 2 & Grupo 4 & Grupo 1 & Grupo 3 \\
\hline $\begin{array}{c}\text { Infiltrado } \\
\text { Inflam. }\end{array}$ & 0.30000000 & 0.40000000 & 0.80000000 & 0.80000000 & 0.70000000 & 0.90000000 \\
Necrose & 0.000 & 0.000 & 0.000 & 0.50000000 & 0.000 & 0.000 \\
Células gigant. & 0.00000000 & 0.00000000 & 0.00000000 & 0.00000000 & 0.00000000 & 0.00000000 \\
$\begin{array}{c}\text { Desorg. Tec. } \\
\text { Granulação }\end{array}$ & 0.45000000 & 0.80000000 & 0.90000000 & 0.85000000 & 0.85000000 & 0.95000000 \\
$\begin{array}{c}\text { Trabéculas } \\
\text { Ósseas }\end{array}$ & 1.50000000 & 1.00000000 & 3.00000000 & 3.00000000 & 3.00000000 & 3.000000000 \\
Barreira Óssea & 0.50000000 & 0.00000000 & 1.00000000 & 1.50000000 & 2.00000000 & 2.50000000
\end{tabular}

ANEXO F - Medianas referentes à análise de variância dos grupos experimentais e controle aos 90 dias.

\begin{tabular}{ccccccc} 
& Controle & MTA & Grupo 2 & Grupo 4 & Grupo 1 & Grupo 3 \\
\hline Infiltr.Inflamat. & 0.25000000 & 0.45000000 & 0.80000000 & 0.70000000 & 0.70000000 & 0.50000000 \\
Necrose & 0.000 & 0.000 & 0.000 & 0.000 & 0.000 & 0.000 \\
$\begin{array}{c}\text { Células } \\
\text { gigantes }\end{array}$ & 0.00000000 & 0.00000000 & 0.00000000 & 0.00000000 & 0.000000000 & 0.00000000 \\
Aspec Tec. & 0.40000000 & 0.80000000 & 0.70000000 & 0.80000000 & 0.60000000 & 0.75000000 \\
$\begin{array}{c}\text { Granulação } \\
\text { Trabéculas }\end{array}$ & 0.000000000 & 2.50000000 & 3.000000000 & 3.00000000 & 3.000000000 & 3.00000000 \\
$\begin{array}{c}\text { Ósseas } \\
\text { Barreira Óssea }\end{array}$ & 0.00000000 & 0.50000000 & 0.00000000 & 1.00000000 & 2.00000000 & 3.00000000
\end{tabular}


ANEXO G - Quantificação da presença de plasmócitos e linfócitos observados nas amostras, em função dos períodos experimentais.

\begin{tabular}{|cccc} 
Grupos & 30d & 60d & 90d \\
\hline Grupo 2 & 3 & 4 & 3 \\
Grupo 1 & 1 & 2 & 2 \\
Grupo 4 & 5 & 3 & 2 \\
Grupo 3 & 5 & 4 & 2 \\
Grupo 5 & 1 & 2 & 3 \\
Grupo controle & 0 & 1 & 0
\end{tabular}

ANEXO H - Dados numéricos referentes à análise de variância do infiltrado inflamatório crônico, no período de 30 dias.

Teste KRUSKAL-WALLIS ( $P=0.05)$

$\begin{array}{cccc}\text { Grupo } & \text { Soma de Postos } & \text { Posto médio } & N^{\circ} \text { de valores } \\ \text { Grupo 4 } & 130.000000 & 21.6666666 & 6 \\ \text { Grupo 3 } & 121.000000 & 20.1666666 & 6 \\ \text { Grupo 5 } & 35.5000000 & 7.10000000 & 5 \\ \text { Grupo Controle } & 12.0000000 & 3.00000000 & 4 \\ \text { Grupo 2 } & 60.5000000 & 15.1250000 & 4 \\ \text { Grupo 1 } & 76.0000000 & 19.0000000 & 4\end{array}$

$H C=19.19964 \quad$ Probabilidade $=0.001764$

Teste de DUNN (p=0.05)

\begin{tabular}{cccc} 
Comparação & Diferença & Valor crítico & Interpretação \\
\hline Grupo $4 \times$ Grupo Controle & 18.6666666 & 16.1324555 & Significante \\
Grupo $3 \times$ Grupo Controle & 17.1666666 & 16.1324555 & Significante
\end{tabular}

- Teste MANN WHITNEY (ps0.05)

$\begin{array}{rcc}\text { Comparação } & \text { Probabilidade } & \text { Interpretação } \\ \text { Grupo } 4 \text { X Grupo 5 } & 0.005601 & \text { Significante } \\ \text { Grupo } 3 \text { X Grupo 5 } & 0.010236 & \text { Significante } \\ \text { Grupo } 2 \text { X Grupo 5 } & 0.031746 & \text { Significante } \\ \text { Grupo } 1 \text { X Grupo 5 } & 0.031746 & \text { Significante } \\ \text { Grupo 2X Grupo Controle } & 0.028572 & \text { Significante } \\ \text { Grupo 1 X Grupo Controle } & 0.028572 & \text { Significante }\end{array}$


ANEXO I - Dados numéricos referentes à análise de variância da intensidade do infiltrado inflamatório crônico, no período de 60 dias.

- Teste KRUSKAL-WALLIS ( $p \leq 0.05)$

$\begin{array}{cccc}\text { Grupo } & \text { Soma de Postos } & \text { Posto médio } & \text { N. de valores } \\ \text { Grupo 4 } & 114.500000 & 19.0833333 & 6 \\ \text { Grupo 3 } & 118.500000 & 19.7500000 & 6 \\ \text { Grupo 5 } & 64.5000000 & 12.9000000 & 5 \\ \text { Grupo Controle } & 17.5000000 & 4.37500000 & 4 \\ \text { Grupo 2 } & 103.500000 & 20.7000000 & 5 \\ \text { Grupo 1 } & 109.500000 & 18.2500000 & 6\end{array}$

$\mathrm{HC}=9.962189 \quad$ Probabilidade $=0.076313$

ANEXO J - Dados numéricos referentes à análise de variância da intensidade do infiltrado inflamatório crônico, no período de 90 dias.

- Teste KRUSKAL-WALLIS ( $\mathrm{p} \leq 0.05$ )

$\begin{array}{cccc}\text { Grupo } & \text { Soma de Postos } & \text { Posto médio } & \text { N. de valores } \\ \text { Grupo 4 } & 130.500000 & 21.7500000 & 6 \\ \text { Grupo 3 } & 99.5000000 & 16.5833333 & 6 \\ \text { Grupo 5 } & 74.5000000 & 12.4166666 & 6 \\ \text { Grupo Controle } & 13.0000000 & 3.25000000 & 4 \\ \text { Grupo 2 } & 117.000000 & 23.4000000 & 5 \\ \text { Grupo 1 } & 93.5000000 & 18.7000000 & 5\end{array}$

$H C=14.21917 \quad$ Probabilidade $=0.014275$

Teste de DUNN ( $\mathrm{p}=0.05)$

\begin{tabular}{cccc} 
Comparação & Diferença & Valor crítico & Interpretação \\
\hline Grupo 4 X Grupo Controle & 18.5000000 & 17.7734939 & SIGNIFICANTE \\
Grupo 2 X Grupo Controle & -20.150000 & 18.4707567 & SIGNIFICANTE
\end{tabular}

ANEXO K - Dados numéricos provenientes da análise de variância relativa à presença de células gigantes multinucleadas no período de 30 dias.

- Teste KRUSKALL WALLIS (p<0.05)

\begin{tabular}{cccc|} 
Grupo & Soma de Postos & Posto médio & N. de valores \\
Grupo 4 & 106.000000 & 17.6666666 & 6 \\
Grupo 3 & 91.5000000 & 15.2500000 & 6 \\
Grupo 5 & 54.5000000 & 10.9000000 & 5 \\
Grupo Controle & 46.5000000 & 11.6250000 & 4 \\
Grupo 2 & 61.0000000 & 15.2500000 & 4 \\
Grupo 1 & 75.5000000 & 18.8750000 & 4
\end{tabular}

$H C=4.284444 \quad$ Probabilidade $=0.509230$ 
ANEXO L - Dados numéricos provenientes da análise de variância relativa à presença de células gigantes multinucleadas no período de 60 dias.

- Teste KRUSKALL WALLIS ( $\mathrm{p}=0.05)$

$\begin{array}{rccc}\text { Grupo } & \text { Soma de Postos } & \text { Posto médio } & \text { N. de valores } \\ \text { Grupo 4 } & 104.000000 & 17.3333333 & 6 \\ \text { Grupo 3 } & 104.000000 & 17.3333333 & 6 \\ \text { Grupo 5 } & 76.0000000 & 15.2000000 & 5 \\ \text { Grupo Controle } & 48.0000000 & 12.0000000 & 4 \\ \text { Grupo 2 } & 92.0000000 & 18.4000000 & 5 \\ \text { Grupo 1 } & 104.000000 & 17.3333333 & 6\end{array}$

$H C=2.246376 \quad$ Probabilidade $=0.814109$

ANEXO M - Dados numéricos provenientes da análise de variância relativa à presença de células gigantes multinucleadas no período de 90 dias.

- Teste KRUSKALL WALLIS ( $\mathrm{P}=0.05$ )

$\begin{array}{cccc}\text { Grupo } & \text { Soma de Postos } & \text { Posto médio } & \text { N. de valores } \\ \text { Grupo 4 } & 119.000000 & 19.8333333 & 6 \\ \text { Grupo 3 } & 103.000000 & 17.1666666 & 6 \\ \text { Grupo 5 } & 87.0000000 & 14.5000000 & 6 \\ \text { Grupo Controle } & 58.0000000 & 14.5000000 & 4 \\ \text { Grupo 2 } & 88.5000000 & 17.7000000 & 5 \\ \text { Grupo 1 } & 72.5000000 & 14.5000000 & 5\end{array}$

$\mathrm{Hc}=4.723809 \quad$ Probabilidade $=0.450507$

ANEXO N - Dados numéricos relativos à análise de variância do grau de organização do tecido de granulação observado no período de 30 dias.

Teste KRUSKALL WALLIS ( $p=0.05)$

$\begin{array}{cccc}\text { Grupo } & \text { Soma de Postos } & \text { Posto médio } & \text { N. de valores } \\ \text { Grupo 4 } & 110.000000 & 18.3333333 & 6 \\ \text { Grupo 3 } & 123.000000 & 20.5000000 & 6 \\ \text { Grupo 5 } & 40.0000000 & 8.00000000 & 5 \\ \text { Grupo Controle } & 12.5000000 & 3.12500000 & 4 \\ \text { Grupo 2 } & 69.5000000 & 17.3750000 & 4 \\ \text { Grupo 1 } & 80.0000000 & 20.0000000 & 4\end{array}$

$H C=16.38193 \quad$ Probabilidade $=0.005834$

- Teste de DUNN ( $p=0.05)$

$\begin{array}{cccc}\text { Comparação } & \text { Diferença } & \text { Valor crítico } & \text { Interpretação } \\ \text { Grupo } 3 \text { X Grupo Controle } & 17.3750000 & 16.1324555 & \text { SIGNIFICANTE }\end{array}$


ANEXO O - Dados numéricos relativos à análise de variância do grau de organização do tecido de granulação observado no período de 60 dias.

Teste KRUSKAL-WALLIS ( $\mathrm{p}=0.05)$

$\begin{array}{rccc}\text { Grupo } & \text { Soma de Postos } & \text { Posto médio } & \text { N. de valores } \\ \text { Grupo 4 } & 104.500000 & 17.4166666 & 6 \\ \text { Grupo 3 } & 121.500000 & 20.2500000 & 6 \\ \text { Grupo 5 } & 82.5000000 & 16.5000000 & 5 \\ \text { Grupo Controle } & 18.0000000 & 4.50000000 & 4 \\ \text { Grupo 2 } & 97.0000000 & 19.4000000 & 5 \\ \text { Grupo 1 } & 104.500000 & 17.4166666 & 6\end{array}$

$\mathrm{HC}=8.188232 \quad$ Probabilidade $=0.146162$

ANEXO P - Dados numéricos relativos à análise de variância do grau de organização do tecido de granulação, no período de 90 dias.

- Teste KRUSKAL-WALLIS ( $\mathrm{P}=0.05)$

$\begin{array}{cccc}\text { Grupo } & \text { Soma de Postos } & \text { Posto médio } & \text { N. de valores } \\ \text { Grupo 4 } & 114.000000 & 19.0000000 & 6 \\ \text { Grupo 3 } & 98.0000000 & 16.3333333 & 6 \\ \text { Grupo 5 } & 121.500000 & 20.2500000 & 6 \\ \text { Grupo Controle } & 21.5000000 & 5.37500000 & 4 \\ \text { Grupo 2 } & 99.0000000 & 19.8000000 & 5 \\ \text { Grupo 1 } & 74.0000000 & 14.8000000 & 5\end{array}$

$\mathrm{Hc}=7.910035 \quad$ Probabilidade $=0.161263$

ANEXO O - Dados numéricos provenientes da análise de variância quanto à presença de necrose tecidual observada no período de 30 dias.

- Teste KRUSKAL-WALLIS $(p=0.05)$

$\begin{array}{cccc}\text { Grupo } & \text { Soma de Postos } & \text { Posto médio } & \text { N. de valores } \\ \text { Grupo 4 } & 114.500000 & 19.0833333 & 6 \\ \text { Grupo 3 } & 114.500000 & 19.0833333 & 6 \\ \text { Grupo 5 } & 35.0000000 & 7.00000000 & 5 \\ \text { Grupo Controle } & 28.0000000 & 7.00000000 & 4 \\ \text { Grupo 2 } & 71.5000000 & 17.8750000 & 4 \\ \text { Grupo 1 } & 71.5000000 & 17.8750000 & 4\end{array}$

$H C=15.63782 \quad$ Probabilidade $=0.007957$ 
- Teste MANN WHITNEY (p $\leq 0.05)$

$\begin{array}{ccc}\text { Comparação } & \text { Probabilidade } & \text { Interpretação } \\ \text { Grupo } 4 \text { X Grupo 5 } & 0.008408 & \text { Significante } \\ \text { Grupo } 4 \text { X Grupo Controle } & 0.014306 & \text { Significante } \\ \text { Grupo } 3 \text { X Grupo 5 } & 0.030304 & \text { Significante } \\ \text { Grupo 3 X Grupo Controle } & 0.038096 & \text { Significante }\end{array}$

ANEXO R - Dados numéricos provenientes da análise de variância quanto à presença de necrose tecidual, no período de 60 dias.

Teste KRUSKAL-WALLIS ( $\mathrm{P}=0.05)$

\begin{tabular}{|cccc}
\hline Grupo & Soma de Postos & Posto médio & N. de valores \\
\hline Grupo 4 & 120.000000 & 20.0000000 & 6 \\
Grupo 3 & 104.000000 & 17.3333333 & 6 \\
Grupo 5 & 60.0000000 & 12.0000000 & 5 \\
Grupo Controle & 48.00000000 & 12.00000000 & 4 \\
Grupo 2 & 92.0000000 & 18.4000000 & 5 \\
Grupo 1 & 104.000000 & 17.3333333 & 6 \\
\hline
\end{tabular}

$H C=5.281481 \quad$ Probabilidade $=0.382502$

ANEXO S - Dados numéricos provenientes da análise de variância quanto à presença de necrose tecidual, no período de 90 dias.

- Teste KRUSKAL-WALLIS $(\mathrm{p}=0.05)$

\begin{tabular}{|cccc|}
\hline Grupo & Soma de Postos & Posto médio & N. de valores \\
\hline Grupo 4 & 99.0000000 & 16.5000000 & 6 \\
Grupo 3 & 99.0000000 & 16.5000000 & 6 \\
Grupo 5 & 99.0000000 & 16.5000000 & 6 \\
Grupo Controle & 66.0000000 & 16.5000000 & 4 \\
Grupo 2 & 82.5000000 & 16.5000000 & 5 \\
Grupo 1 & 82.5000000 & 16.5000000 & 5 \\
\hline
\end{tabular}

$\mathrm{Hc}=0.000000 \quad$ Probabilidade $=1.000$

ANEXO T - Dados numéricos referentes à análise de variância da quantidade de trabéculas ósseas adjacentes à extremidade do tubo, observadas no período de 30 dias.

- Teste KRUSKAL-WALLIS ( $p=0.05)$

$\begin{array}{cccc}\text { Grupo } & \text { Soma de Postos } & \text { Posto médio } & \text { N. de valores } \\ \text { Grupo 4 } & 85.0000000 & 14.1666666 & 6 \\ \text { Grupo 3 } & 63.0000000 & 10.5000000 & 6 \\ \text { Grupo 5 } & 111.000000 & 22.2000000 & 5 \\ \text { Grupo Controle } & 92.0000000 & 23.0000000 & 4 \\ \text { Grupo 2 } & 42.0000000 & 10.5000000 & 4 \\ \text { Grupo 1 } & 42.0000000 & 10.5000000 & 4\end{array}$

$\mathrm{Hc}=16.51139 \quad$ Probabilidade $=0.005526$ 
Teste MANN WHITNEY ( $p \leq 0.05)$

Comparação

Grupo 4 X Grupo 5

Grupo 4 X Grupo Controle Grupo $3 \times$ Grupo 5

\section{Probabilidade}

0.034264

0.066934

0.030304

\section{Interpretação}

Significante

Significante

Significante

ANEXO U - Dados numéricos referentes à análise de variância da quantidade de trabéculas ósseas adjacentes à extremidade do tubo, observadas no período de 60 dias.

- Teste KRUSKAL-WALLIS ( $\mathrm{P}=0.05)$

$\begin{array}{cccc}\text { Grupo } & \text { Soma de Postos } & \text { Posto médio } & \text { N. de valores } \\ \text { Grupo 4 } & 85.5000000 & 14.2500000 & 6 \\ \text { Grupo 3 } & 72.0000000 & 12.0000000 & 6 \\ \text { Grupo 5 } & 109.000000 & 21.8000000 & 5 \\ \text { Grupo Controle } & 86.0000000 & 21.5000000 & 4 \\ \text { Grupo 2 } & 60.0000000 & 12.0000000 & 5 \\ \text { Grupo 1 } & 115.500000 & 19.2500000 & 6\end{array}$

$H C=9.779016 \quad$ Probabilidade $=0.081744$

ANEXO V - Dados numéricos referentes à análise de variância da quantidade de trabéculas ósseas adjacentes à extremidade do tubo, observadas no período de 90 dias.

- Teste KRUSKAL-WALLIS ( $\mathrm{P}=0.05)$

$\begin{array}{rrrc}\text { Grupo } & \text { Soma de Postos } & \text { Posto médio } & \text { N. de valores } \\ \text { Grupo 4 } & 84.0000000 & 14.0000000 & 6 \\ \text { Grupo 3 } & 84.0000000 & 14.0000000 & 6 \\ \text { Grupo 5 } & 132.000000 & 22.0000000 & 6 \\ \text { Grupo Controle } & 88.0000000 & 22.0000000 & 4 \\ \text { Grupo 2 } & 70.0000000 & 14.0000000 & 5 \\ \text { Grupo 1 } & 70.0000000 & 14.0000000 & 5\end{array}$

$\mathrm{Hc}=12.53676 \quad$ Probabilidade $=0.028128$

- Teste MANN WHITNEY (p $\leq 0.05)$

$\begin{array}{ccc}\text { Comparação } & \text { Probabilidade } & \text { Interpretação } \\ \text { Grupo } 4 \text { X Grupo Controle } & 0.016157 & \text { Significante } \\ \text { Grupo } 3 \times \text { Grupo Controle } & 0.016157 & \text { Significante }\end{array}$


ANEXO W - Dados relativos à análise de variância da quantidade de barreira óssea presente entre o tecido medular e tecido fibroso, observada no período de 30 dias.

- Teste KRUSKAL-WALLIS ( $\mathrm{p}=0.05)$

$\begin{array}{rrrc}\text { Grupo } & \text { Soma de Postos } & \text { Posto médio } & \text { N. de valores } \\ \text { Grupo 4 } & 84.5000000 & 14.0833333 & 6 \\ \text { Grupo 3 } & 58.5000000 & 9.75000000 & 6 \\ \text { Grupo 5 } & 100.000000 & 20.0000000 & 5 \\ \text { Grupo Controle } & 75.0000000 & 18.7500000 & 4 \\ \text { Grupo 2 } & 56.5000000 & 14.1250000 & 4 \\ \text { Grupo 1 } & 60.5000000 & 15.1250000 & 4\end{array}$

$H C=5.488489 \quad$ Probabilidade $=0.359209$

ANEXO X - Dados relativos à análise de variância da quantidade de barreira óssea presente entre o tecido medular e tecido fibroso, observada no período de 60 dias.

- Teste KRUSKAL-WALLIS $(P=0.05)$

$\begin{array}{rrcc}\text { Grupo } & \text { Soma de Postos } & \text { Posto médio } & \text { N. de valores } \\ \text { Grupo 4 } & 83.0000000 & 13.8333333 & 6 \\ \text { Grupo 3 } & 71.0000000 & 11.8333333 & 6 \\ \text { Grupo 5 } & 110.500000 & 22.1000000 & 5 \\ \text { Grupo Controle } & 74.5000000 & 18.6250000 & 4 \\ \text { Grupo 2 } & 93.0000000 & 18.6000000 & 6 \\ \text { Grupo 1 } & 96.0000000 & 16.0000000 & 6\end{array}$

$H C=4.510419 \quad$ Probabilidade $=0.478490$

ANEXO Y - Dados relativos à análise de variância da quantidade de barreira óssea presente entre o tecido medular e tecido fibroso, observada no período de 90 dias.

- Teste KRUSKAL-WALLIS ( $\mathrm{p}=0.05)$

$\begin{array}{cccc}\text { Grupo } & \text { Soma de Postos } & \text { Posto médio } & \text { N. de valores } \\ \text { Grupo 4 } & 90.0000000 & 15.0000000 & 6 \\ \text { Grupo 3 } & 60.0000000 & 10.0000000 & 6 \\ \text { Grupo 5 } & 117.500000 & 19.5833333 & 6 \\ \text { Grupo Controle } & 89.0000000 & 22.2500000 & 4 \\ \text { Grupo 2 } & 105.000000 & 21.0000000 & 5 \\ \text { Grupo 1 } & 66.5000000 & 13.3000000 & 5\end{array}$

$\mathrm{HC}=7.638531 \quad$ Probabilidade $=0.177314$ 


\title{
ANEXO Z - Reprodução do parecer do Comitê de Ética no Ensino e Pesquisa em Animais.
}

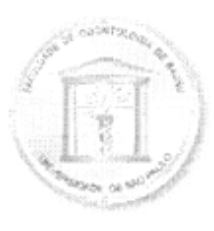

\author{
Universidade de São Paulo \\ Faculdade de Odontologia de Bauru \\ Al. Dr. Octávio Pinheiro Brisolla, 9-75 - Bauru-SP - CEP 17012-901 - C.P. 73 \\ PABX (0XX14)235-8000 - FAX (0XX14)223-4679 \\ Comissão de Ética no Ensino e Pesquisa em Ánimais
}

CEEPA-Proc. $N^{o} 40 / 2003$

Bauru, 05 de dezembro de 2003

Senhor Professor,

O projeto de pesquisa encaminhado a esta Comissão de Ética no Ensino e Pesquisa em Animais, denominado "Avaliação do potencial inflamatório crônico produzido por pasta de impressão LS acrescida de radiopacificantes e hidróxido de cálcio: estudo em tíbia de ratos (Rattus novegicus-albinus)“, de autoria de Augusto Bodanezi, a ser desenvolvido sob sua orientação, foi enviado ao relator para avaliação.

Na reunião de 02 de dezembro de 2003 esta Comissão aprovou o parecer do relator, considerando que não existem infrações éticas.

Atenciosamente,

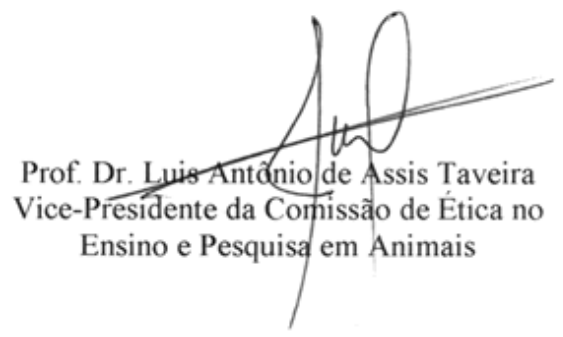

$\mathrm{Ilm}^{\circ} \mathrm{Sr}$. Prof. Dr. Norberti Bernardineli

DD. Docente do Departamento de Dentística, Endodontia e Materiais Dentários 
REFERÊNCIAS BIBLIOGRÁFICAS 


\section{REFERÊNCIAS BIBLIOGRÁFICAS}

1 ALAÇAM, T.; GÖRGÜL, G.; ÖMÜRLÜ, H. Evaluation of diagnostic radiopaque contrast materials uses with calcium hydroxide. J Endod., v. 16, n.8, p.365-8, Aug. 1990.

2 ALTONEN, M.; MATTILA, K. Follow-up study of apicoectomized molars. Int J Oral Surg., v.5, n. 1, p.33-40, Jan. 1976.

3 AUSTIN, B.P. et al. Osseous reaction to bimetalic couples composed of amalgam and gold implanted in rat tibias. Oral Surg., v.54, n. 1, p.79-92, July 1982.

4 BATES, C.; CARNES,D.L.; DEL RIO, C.E. Longitudinal sealing ability of mineral trioxide aggregate as a root-end filling material. J Endod., v.22, n.11, p.575-8, Nov. 1996.

5 BHAMBHANI, S.M.; BOLANOS, O.R. Tissue reactions to endodontic materials implanted in the mandibles of guinea pigs. Int End J., v.76, n.4, p.493-501, Oct. 1993.

6 BERBERT, A. Comportamento dos tecidos apicais e periapicais após biopulpectomia e obturação do canal com AH26, hidróxido de cálcio ou mistura de ambos. Bauru, 1978. 174p. Tese (LivreDocência) Faculdade de Odontologia de Bauru, Universidade de São Paulo. 
7 BERNARDINELI, N. Obturação retrógrada - avaliação ao microscópio eletrônico de varredura da adaptação às paredes das cavidades e infiltração marginal em função de materiais obturadores e agentes de limpeza. Bauru, 1993. 168p. Tese (Livre-Docência) Faculdade de Odontologia de Bauru, Universidade de São Paulo.

8 BERNARDINELI, N. Comunicação pessoal.

9 BODANEZI, A.; BERNARDINELI, N. Comparação digital do grau de radiopacidade produzido por quatro substâncias encontradas nos cimentos obturadores endodônticos. (trabalho ainda não publicado)

10 BORTOLUZZI, E.A. Avaliação da reação do tecido subcutâneo de ratos à implantação dos cimentos MTA e Portland brancos acrescidos de radiopacificadores. Bauru, 2005. 191p. Dissertação (Mestrado) Faculdade de Odontologia de Bauru, Universidade de São Paulo.

11 BOYNE, P.J. Current status of osseous tissue induction-theory and practice. J Periodontol., v.43, n. 1, p.47, Jan. 1972.

12 BRAMANTE, C.M. Tratamento de perfurações radiculares com pasta de hidróxido de cálcio e iodofórmio - influência do período de troca - estudo histológico em dentes de cães. Bauru, 1980. 112p. Tese (Livre-docência) - Faculdade de Odontologia de Bauru, Universidade de São Paulo.

13 BRAMANTE, C.M.; BERBERT, A. Cirurgia paraendodôntica. São Paulo, Ed. Santos, 2001 . Cap. 15, p.73-92. 
14 BRUCE, G.R.; MCDONALD, N.J.; SYDISKIS, R.J Citotoxicity of retrofill materials. J Endod., v.19, n.6, p.288-92, June 1993.

15 CAICEDO, R. et al. Sealing capacity of super-eba, pro root, (MTA), diaket in the repair of root perforations. J Endod., v.26, n.9, p.553, sep. 2000.

16 CALEGARI-JAOUES, S.M. Bioestatística - princípios e aplicações. Porto Alegre, Artmed, 2003. Cap. 18, p. 165-84.

17 CAMPS, J.; et al. Influence of powder/liquid ratio on the properties of zinc oxide-eugenol-based root canal sealers. Dental Materials 2004 (article in press)

18 CARR, G.B.; BENTKOVER, S.K. Cirurgia em endodontia. In: COHEN, S.; BURNS, R.C. Caminhos da polpa. 7ed. Rio de Janeiro, Guanabara Koogan, 2000. Cap. 18, p. 573-621.

19 CARVALHO, A.F. et al. Addition of bismuth subnitrate to omeprazole plus amoxicillin improves eradication of Helicobacter pilori. Aliment Pharmacol Ther., v. 12, n.6, p.557-61, Jul. 1998.

20 CHONG, B.S.; PITT FORD, T.R.; KARIYAWASAM, S.P. Tissue response to potential root-end filling materials in infected root canals. Int End J., v.30, n.2, p.102-14, Feb. 1997. 
21 CHONG, B.S.; PITT FORD, T.R.; HUDSON, M.B. A prospective clinical study of mineral trioxide aggregate and IRM when used as rootend filling materials in endodontic surgery. Int End J., v.36, n.8, p.520-6, Aug. 2003.

22 COTRAN, R.S.; KUMAR,V.; COLLINS, T. Patologia estrutural e funcional. Ged. Guanabara Koogan, Rio de Janeiro, 2000. Cap. 4, p. 79-100.

23 CRAIG, K.R.; HARRISON, J.W. Wound healing following demineralization of resected root ends in periradicular surgery. J Endod., v.19, n. 7 p.339-47, 1993.

24 CUSTÓDIO, A.L.N. Avaliação do vedamento apical de quatro materiais odontológicos utilizados em obturações retrógradas. Porto Alegre, 1994. 108p. Dissertação (Mestrado) - Faculdade de Odontologia da Pontifícia Universidade Católica do Rio Grande do Sul.

25 DANIEL, R.L.D.P.; JAEGER, M.M.M.; MACHADO, M.E.L. Emprego do iodofórmio em endodontia - revisão da literatura. Rev Pós Grad., v.6, n.2, p. 175-9, abr/jun. 1999.

26 DE BRUYNE, M.A.A.; DE MOOR, R.J.G. The use of glass ionomers in both conventional and surgical endodontics. Int End J., v.37, n.2, p.91-105, Feb. 2004.

27 DEEMER, J.P.; TSAKNIS, P.J. The effects of overfilled polyethylene tube intraosseous implants in rats. Oral Surg., v.48, n.4, p.358-73, Oct.. 1979. 
28 DUARTE, M.A.H. et al. Evaluation of $\mathrm{pH}$ and calcium ion release of three root canal sealers. J Endod., v. 26, n.7, p.389-90, July 2000.

29 DUTRA, C.E.A. Estudo da capacidade de vedamento da pasta lysanda ${ }^{\circledR}$ (zinco-enólica) em obturação retrógrada: estudo realizado em cães. Porto Alegre, 1993. 70p. Dissertação (Mestrado) - Faculdade de Odontologia da Pontifícia Universidade Católica do Rio Grande do Sul.

30 ECONOMIDES, N. et al. Short-term periradicular tissue response to mineral trioxide aggregate (MTA) as root-end filling material. Int End J., v.36, n. 1, p.44-8, Jan. 2003.

31 ETHER, S.S.; ROTHIER, A.; HALFELD, G. Cronologia endodôntica. Rio de Janeiro, Gráfica UERJ, 1990. p. 24-49.

32 EURASOUIN, J. et al. Necrosis of the periodontal ligament in root canal overfillings. J Dent Res., v.45, n.4, p. 1094-1 102, July/Aug. 1966.

33 EURASOUIN, J.; MURUZÁBAL, M. Tissue reaction to root canal fillings with absorbable pastes. Oral Surg., v.28, n.4, p.567-78, Oct. 1969

34 FAVA, L.R.; SAUNDERS, W.P. Calcium hydroxide - classification and clinical indications. Int End J., v.32, n.6, p. 257-82, June 1999. 
35 FIGUEIREDO, J.A.P. et al. The histological effects of four endodontic sealers implanted in the oral mucosa - submucous injection versus implant in polyethylene tubes. Int End J., v.34, n.6, p.37785, June 2001.

36 FRIEND, L.A.; BROWNE, R.M. Tissue reactions to some root filling materials. Brit Dent J., v.125, n.1, p.291-8, Oct. 1968.

37 FRIEND, L.A.; BROWNE, R.M. Tissue reactions to some root filling materials implanted in bone of rabbits. Arch Oral Biol., v. 14, n.5, p.629-381, May 1969.

38 FUJISAWA, S. et al. Interaction between 2-ethoxybenzoic acid (EBA) and eugenol, and related changes in cytotoxicity. J Dent Res., v.82, n. 1, p.43-7, Jan. 2003.

39 GOMES DE MORAES, I.; TAVANO, O.; BERBERT, A. Radiopacidade de materiais obturadores de canal radicular. Odontol Mod., v. 15, n.8, p.30-8, Set. 1988.

40 GROSSMAN, L.I.; OLIET, S.; DEL RIO, C.E. Endodontic practice. 1 led Philadelphia, Lea \& Febiger, 1988.

41 GUIDUGLI NETO, J.; MAGALHÃES, J.; WEINFELD, I. Modelo para estudo morfológico da reparação Odonto v.1, n.1, p.18-9, abr/mai. 1991.

42 HARRISON, J.W.; MADONIA, J.V. The toxicity of parachlorophenol. Oral Surg., v.32, n.1, p. 90-9, July1971. 
43 HOLLAND, R. et al. Resposta do tecido conjuntivo subcutâneo do rato ao implante de alguns materiais obturadores de canal. Rev Fac Odontol Araçatuba. v.2, n.2, p. 217-25, Fev. 1973.

44 HOLLAND, R. et al. Resposta tecidual à implantação de diferentes marcas de cones de guta-percha - estudo histológico em ratos. Rev Fac Odontol Araçatuba, v.4, n. 1, p.81-9, Jan. 1975.

45 HOLLAND, R. et al. Acción y velocidad de reabsorción de distintos materiales de obturación de conductos radiculares em el tejido conectivo periapical. Rev Assoc Odont Argentina, v.69, n. 1, p.716, Jan. 1981.

46 HOLLAND, G.R.; et al. Comportamento dos tecidos periapicais de dentes de cães após a obturação de canal com sealapex acrescido ou não de iodofórmio. Rev Odont UNESP, v. 19, n. 1, p. 97-105, jan. 1990.

47 HOLLAND, R. et al. Reaction of rat connective tissue to implanted dentin tubes filled with mineral trioxide aggregate or calcium hydroxide. J Endod., v.25, n.3, p. 161-6, Mar. 1999.

48 HOLLAND, R. et al. Calcium salts deposition in rat connective tissue after the implantation of calcium hydroxide-containing sealers. J Endod., v.28, n.3, p. 173-6, Mar. 2002. 
49 HOUAISS, A.; VILLAR, M.S.; FRANCO, F.M. Dicionário eletrônico houaiss da lígua portuguesa. Versão 1.0 São Paulo, Objetiva, 2001.

50 HUME, W.R. An analysis of the release and the diffusion through dentin of eugenol from zinc oxide-eugenol mixtures. J Dent Res., v.63, n.6, p.881-4, Dec. 1984

51 HUME, W.R. The pharmacologic and toxicological properties of zinc oxide-eugenol. J Am Dent Assoc., v.113, n.5, p.789-91, Nov. 1986.

52 IODINE. Iodoform. Disponivel em: http://iodine.com/iodoform.htm 2004. Acesso em 26 jul. 2004.

53 JUNOUEIRA, L.C.; CARNEIRO, J. Histologia básica. 10ed Rio de Janeiro, Guanabara Koogan, 2004. Cap. 8, p.136-153.

54 KAKEHASHI, S.; STANLEY, H.R.; FITZGERALD,R.J. The effects of surgical exposure of dental pulps in germ-free and conventional laboratory rats. Oral Surg., v.20, n.XX, p.340-9, XXXX. 1968.

55 KLEIN JÚNIOR, C.A.; Et al. Avaliação laboratorial do tempo de presa da pasta de óxido de zinco-eugenol acrescida de retardadores e aceleradores. PCL v.3, n.16. nov/dez 200 1. p.446-50.

$56 \mathrm{KOH}$, E.T. et al. Mineral trioxide aggregate stimulates a biological response in human osteoblasts. J Biomed Mater Res., v.37, n. 1, p.432-9, Oct. 1997. 
57 KOLA, I. Putting the rat on the map. Nature, v.22, n.5, p.529-31, May 2004.

58 KRINKLE G.J. The laboratory rat. San Diego, Academic Press, 2000.

59 KUGA, M.C.; MORAES, I.G.; BERBERT, A. Capacidade seladora do cimento Sealapex puro ou acrescido de iodofórmio. Rev Odont USP., v.2, n.3, p.139-42, jul./set. 1988.

60 LANGELAND, K. Root canal sealants and pastes. Dent. Clin North Am., v. 18, n.2, p.309-27, April 1974.

61 LANGELAND, K. et al. Methods in the study of biologic responses to endodontic materials. Oral Surg., v.27, n.4, p.522-42, April 1969.

62 LEE, S.J.; MONSEF, M.; TORABINEJA, M. The sealing ability of a mineral trioxide aggregate for repair of lateral root perforations. J Endod., v. 19, n. 11 , p.541-44, Nov. 1993.

63 LU, J.X. et al. Comparative study of tissue reactions to calcium phosphate ceramics among cancellous, cortical and medullar bone sites in rabbits. J Biomed Mat Res., v.42, n.3, p.357-67, Dec. 1998.

64 MAISTO, O.A.; EURASOUIM, J. Reacción de los tejidos periapicales del molar de la rata a las pastas de obturación, reabsorbibles. Rev Assoc Odontol Argent v.53, n. 1, p. 12-20, Jan. 1965. 
65 MAKKES, P.C. et al. Polyethylene tubes as a model for the root canal. Oral Surg., v.44, n. 1, p.293-300, July 1977.

66 MANGIN, C. et al. The comparative sealing abiligy of hidroxiapatite cement, mineral trioxide aggregate, and super ethoxybenzoic acid as root-end filling materials. J Endod., v.29, n.4, p.261-4, April 2003.

67 MARKOWITZ, K. et al. Biologic properties of eugenol and zinc oxideeugenol - a clinically oriented review. Oral Surg., v.73, n. 10, p. 729-37, Oct. 1992.

68 MARTELL, B.; CHANDLER, N.P. Electrical and dye leakage comparison of MTA, Super Eba and IRM. J Endod., v.26, n.9, p.545, Sept. 2000.

69 MOLNAR, E.J. Residual eugenol from zinc oxide eugenol compounds. J Dent Res., v.46, n.8, p.645-9, Aug. 1967.

70 MITTAL, M.; CHANDRA, S.; CHANDRA, S. Comparative tissue toxicity evaluation of four endodontic sealers. J Endod., v.21,n.12, p.622-4, Dec. 1995.

71 MORAIS, C.A.H. Avaliação microscópica da reação tecidual à implantação do MTA (Pro Root®), cimento Portland com iodofórmio e pasta Lysanda $\circledR$, no tecido conjuntivo subcutâneo de ratos. Bauru, 2003. 148p. Tese (Doutorado) - Faculdade de Odontologia de Bauru, Universidade de São Paulo. 
72 MORETTON, T.R. et al. Tissue reactions after subcutaneous and intraosseous implantation of mineral trioxide aggregate and ethoxybenzoic acid cement. J Biomat Res., v.52, n.3, p.528-33, Dec. 2000.

73 OKAMOTO, T. et al. Homogenous implant in rat tibias of matrix preserved in 98\% glycerin - histomorphologic study. Braz Dent J., v.11, n.2, p.79-87, Feb. 2000.

74 OLIVEIRA, A.S. Análises histopatológicas do tecido conjuntivo subcutâneo de ratos a implantes do cimento $\mathrm{AH}-26$ puro e acrescido de hidróxido de cálcio em diversas proporções. Bauru, 1977. 110p. Dissertação (Mestrado) - Faculdade de Odontologia de Bauru, Universidade de São Paulo.

75 OLSEN, F.K.; AUSTIN, B.P.; WALIA, H. Osseous reaction to implanted ZOE retrograde filling materials in the tibia of rats. J Endod., v.20, n.8, p.389-94, Aug. 1994.

76 OLSSON, B.; SLIWKOWSKI, A.; LANGELAND, K. Intraosseous implantation for biological evaluation of endodontic materials. J Endod., v.7, n.6, p.253-65, June 1981.

77 OYNICK, J.; OYNICK, T. A study of a new material for retrograde fillings. J Endod., v.4, n.7, p.203-6, July 1978.

78 PASCON, E.A. et al. Tissue reaction to endodontic materials: methods, criteria, assessment, and observations. Oral Surg., v.72, n.8, p.222-37, Aug. 1991. 
79 PASSERI, L.A.; CARVALHO, A.C.P. Biocompatibility of tissue conditioners - histological study in rats. J Nihon Univ Sch Dent., v.27, n.3, p. 167-73, Mar. 1985. APUD CARVALHO, A.C.P.; OKAMOTO, T. Cirurgia bucal - fundamentos experimentais aplicados à clínica. São Paulo, Panamericana, 1987. Cap. 6, p.81-96.

80 PASSERI, L.A. et al. The use of tissue conditioner or zinc oxide and eugenol. J Nihon Univ Sch Dent.., v.29, n.2, p.87-92, June 1987.

81 PERTOT, W. et al. In vivo comparison of the biocompatibility of two root canal sealers implanted into the mandibular bone of rabbits. Oral Surg., v. 73, n.5, p.613-20, May 1992.

82 PHILLIPS, J.P. Rat connective tissue response to hollow polyethylene tube implants. J Canad Dent Asssoc., v.33, n.2, p.59-64, Feb. 1967.

83 PISSIOTIS, E. et al. Reaction of bony tissue to implanted silver glass ionomer and a reinforced zinc oxide-eugenol cement. Oral Surg., v.89, n.5, p. 623-9, May 2000.

84 PITT FORD, T.R. Tratamento cirúrgico da periodontite apical. In: ØRSTAVIK, D.; PITT FORD, T.R. Fundamentos da endodontia prevenção e tratamento da periodontite apical. São Paulo, Ed. Santos, 2004. Cap. 12, p.278-307. 
85 RAMALHO, L.M.P.; SANTANA, E.J.B.; RAMALHO, M.J.P. Influência da proporção pó/líquido nas propriedades biológicas de cimento endodôntico à base de óxido de zinco e eugenol. Rev Odonto Ciência, v. 15, n.29, p.111-23, Jun 2000.

86 RAMOS, C.A.S.; BRAMANTE, C.M. Endodontia - fundamentos biológicos e clínicos. 2ed. São Paulo, Ed.Santos, 2001. Cap. 10, p.225-54.

87 SHABAHANG, S. et al. A comparative study of root-end induction using osteogenic protein-1, calcium hydroxide, and mineral trioxide aggregate in dogs. J Endod., v.25, n.1, p. 1-5, Jan. 1999.

88 SHAFER, W.G.; HINE, M.K.; LEVY, B.M. Tratado de patologia bucal. 4ed. Rio de Janeiro, Interamericana, 1985.

89 SHAH, P.M. Radiopacity of potential root end filling materials. Oral Surg., v.81, n.4, p.476-9, April 1996.

90 SOUZA, C.J.A.; Et al. A comparative histological evaluation of the biocompatibility of materials used in apical surgery. Int End J., v.37, n. 11, p.738-48, Nov. 2004.

91 STANDFORD, J.W. Fédération dentaire international recommended standard practices for biological evaluation of dental materials. Int Dent J., v.9, n.2, p. 140-88, Feb. 1980. 
92 STANLEY, H. R. Toxicity testing of dental materials. CRC, Boca Raton, Flórida, 1985. Cap.4, p. 80-86.

93 STASHENKO, P. Etiologia e patogênese das pulpites e das periodontites apicais. In: ØRSTAVIK, D.; PITT FORD, T.R. Fundamentos da endodontia - prevenção e tratamento da periodontite apical. Ed. Santos, São Paulo, 2004. Cap. 3, p.4267.

94 TAGGER, M.; TAGGER, E.; KFIR, A. Release of calcium and hydroxyl ions from set endodontic sealerr containing calcium hydroxide. J Endod., v. 14, n.7, p.588-91, Aug. 1988.

95 TAGGER, M.; KATZ, A. A standard for radiopacity of root-end (retrograde) filling materials is urgently needed. Int End J., v.37, n.5, p. 260-4, May 2004.

96 TANOMARU FILHO, M. et al. Capacidade de selamento apical das técnicas de obturação retrógrada, retroinstrumentação com retrobturação e associação de ambas. Rev Odont USP, v.7, n.2, p. 145-50, abr/jun. 1993.

97 TANOMARU FILHO, M. et al. Effect of different root canal sealers on periapical repair of teeth with chronic periradicular periodontitis. Int End J., v.31, n. 1, p.85-9, Jan. 1998.

98 TAVANO, O. et al. Sialografla das glândulas parótidas e submandibulares. In: Prática Odontológica Rio de Janeiro, Richardson Merrell-Moura Brasil, 1972. 
99 TORABINEJAD, M.;: WATSON, T.F.; PITT FORD, T.R. The sealing ability of a mineral trioxide aggregate as a root end filling material. J Endod., v. 19, n.7, p.591-5, July 1993.

100 TORABINEJAD, M. et al. Bacterial leakage of mineral trioxide aggregate as root-end filling material. J Endod., v.21, n.3, p. $110-12$, Mar. 1995.

101 TORABINEJAD, M. et al. Citotoxicity of four root end filling materials. J Endod., v.21, n. 10, p.489-92, Oct. 1995.

102 TORABINEJAD, M. et al. Tissue reaction to implanted Super-EBA and mineral trioxide aggregate in the mandible of guinea pigs - a preliminary report. J Endod., v.21, n.11, p.569-71, Nov. 1995.

103 TORABINEJAD, M. et al. Investigation of mineral trioxide aggregate for root-end filling in dogs. J Endod., v.21, n.12, p.603-9, Dec. 1995.

104 TORABINEJAD, M. et al. Tissue reaction to implanted root-end filling materials in the tibia and mandible of guinea pigs. J Endod., v.24, n.7, p.468-71, July 1998.

105 TORABINEJAD, M.; CHIVIAN, N. Clinical applications of mineral trioxide aggregate. J Endod., v.25, n.3, p. 197-205, Mar. 1999.

106 TORNECK, C.D. Reaction of rat connective tissue to polyethylene tube implants. Oral Surg., v.21, n.3, p.379-87, March 1966. 
107 TROPE, M. et al. Healing of apical periodontitis in dogs after apicoectomy and retrofilling with various filling materials. Oral Surg., v.81, n.2, p.221-8, Feb. 1996.

108 TROWBRIDGE, H.O.; EMLING, R.C. Inflamação - uma revisão do processo. 4ed. São Paulo, Ouintessence, 1996.

109 WALTIMO, T.M.T.; Et al. Clinical performance of 3 endodontic sealers. Oral Surg v.92, n. 1 p.89-92 Jan. 2001.

110 WEINFELD, I. et al Estudo histológico de um novo material (Biobone) indicado para reparação óssea. Rev Paul Cir Dent., v.21, n.4, p.8-10, jul./ago. 1999.

111 WEISMANN, R.; BRITO, J.H. Resposta tecidual frente a diferentes fios de sutura implantados na língua de ratos. Rev Odonto Ciênc., v.8, n.16, p. 19-31, jul./dez.1993.

112 WENGER, J.S. et al. The effects of partially filled polyethylene tube intraosseous implants in rats. Oral Surg., v.46, n. 1, p.88-100, July 1978.

113 WILSON, A.D.; CLINTON, D.J.; MILLER, R.P. Zinc oxice-eugenol cements - microstruture and hydrolysis. J Dent Res., v.52, n.2, p.253-60, Mar/apr. 1973.

114 WOLFSON, E.M.; SELTZER, S. Reaction of rat connective tissue to some gutta-percha formulations. J Endod., v. 1, n. 12, p.395-402, Dec. 1975. 
115 YALTIRIK, M.; Et al. Reactions of connective tissue to mineral trioxide aggregate and amalgam. J Endod., v.30, n.2, p. 95-99, Feb. 2004.

116 ZARDENETA, G. et al. Protein interaction with particulate teflon implications for the foreign body response. J Oral Maxillofac Surg., v.54, n.7, p.873-8, July 1996.

117 ZUOLO, M.L.; FERREIRA, M.O.F.; GUTMANN, J.L. Prognosis in periradicular surgery: a clinical prospective study. Int End J., v.33, n.2, p.91-8, March 2000. 
ABSTRACT 
Comparative analysis of rat bone marrow tissue to mineral trioxide aggregate or a modified zinc-oxide eugenol sealer.

This study investigated the rat bone marrow healing associated to mineral trioxide aggregate (MTA®- Angelus) or a zinc-oxide impression paste (LSR - Vigodent) added of radiopaque substance (iodoform or bismuth subnitrate) and calcium hydroxide. The control group was composed of empty tubes. The tubes were surgically inserted in the right femur and tibia of 45 rats, resulting in 102 specimens. On each experimental period of 30,60 and 90 days after surgical implantation, seventeen animal were randomly killed, and had their right leg removed to be fixed, decalcified and embedded in parafin. After histological procedures, the tissue phenomena were examined under light microscope, in a blind way, based on a qualitative scale. The statistical tests showed anticipated repair associated with mineral trioxide aggregate $(\rho \geq 0.05)$. No statistical differences were found between inflammatory behaviour of both radiopaque agents ( $p \geq 0.05$ ). The calcium hydroxide powder added to zinc-oxide eugenol sealer seemed not to improve its biological performance ( $\mathrm{p} \geq 0.05)$. 